\title{
Detectability of early lung cancer on the chest radiograph: a study on miss rate and observer performance in clinical practice
}

Citation for published version (APA):

Quekel, L. G. B. A. (2001). Detectability of early lung cancer on the chest radiograph: a study on miss rate and observer performance in clinical practice. [Doctoral Thesis, Maastricht University]. Datawyse / Universitaire Pers Maastricht. https://doi.org/10.26481/dis.20010928lq

Document status and date:

Published: 01/01/2001

DOI:

10.26481/dis.20010928lq

Document Version:

Publisher's PDF, also known as Version of record

Please check the document version of this publication:

- A submitted manuscript is the version of the article upon submission and before peer-review. There can be important differences between the submitted version and the official published version of record.

People interested in the research are advised to contact the author for the final version of the publication, or visit the DOI to the publisher's website.

- The final author version and the galley proof are versions of the publication after peer review.

- The final published version features the final layout of the paper including the volume, issue and page numbers.

Link to publication

\footnotetext{
General rights rights.

- You may freely distribute the URL identifying the publication in the public portal. please follow below link for the End User Agreement:

www.umlib.nl/taverne-license

Take down policy

If you believe that this document breaches copyright please contact us at:

repository@maastrichtuniversity.nl

providing details and we will investigate your claim.
}

Copyright and moral rights for the publications made accessible in the public portal are retained by the authors and/or other copyright owners and it is a condition of accessing publications that users recognise and abide by the legal requirements associated with these

- Users may download and print one copy of any publication from the public portal for the purpose of private study or research.

- You may not further distribute the material or use it for any profit-making activity or commercial gain

If the publication is distributed under the terms of Article $25 \mathrm{fa}$ of the Dutch Copyright Act, indicated by the "Taverne" license above, 


\title{
Detectability of early lung cancer
}

\author{
on the chest radiograph:
}

a study on miss rate and observer

performance in clinical practice 
Druk: Datawyse / Universitaire Pers Maastricht Layout: Thum Aarts

ISBN: $90-5278-315-2$ 


\title{
Detectability of early lung cancer
}

\author{
on the chest radiograph:
}

a study on miss rate and observer

performance in clinical practice

\author{
PROEFSCHRIFT \\ ter verkrijging van de graad van doctor \\ aan de Universiteit Maastricht \\ op gezag van de Rector Magnificus, Prof. dr. A.C. Nieuwenhuijzen Kruseman \\ volgens het besluit van het College van Decanen, \\ in het openbaar te verdedigen \\ op vrijdag 28 september 2001 om 14.00 uur
}

door

Lorentz Godfried Bernhard Alexander Quekel

geboren te Heerlen op 8 april 1963 


\section{Promotor:}

Prof. dr. J.M.A. van Engelshoven

\section{Co-promotor:}

Dr. R. Goei (Atrium Medisch Centrum, Heerlen)

Beoordelingscommissie:

Prof. dr. E. F.M. Wouters (voorzitter)

Dr. E.H.J. van Haren (Atrium Medisch Centrum, Heerlen)

Prof. dr. H.F.P. Hillen

Prof. dr. J.A. Knottnerus 
Aan Marjolein, Martine en Heleen 
: 


\section{Contents}

Chapter 1

1.1 General introduction 9

1.2 Aim of the study $r$

1.3 Description of the study and patient material 13

Chapter 2

Miss rate of lung cancer on the chest radiograph in clinical practice

Chest 1999; 115: 720-724.

Chapter 3

Detection of lung cancer on the chest radiograph:

a study on observer performance

European لoumall of Radiology (in press).

\section{Chapter 4}

Detection of lung cancer on the chest radiograph:

impact of previous films, clinical information, double reading and dual reading Journal of Clinical Epidemiology (in press).

Chapter 5

Missed lung cancer in clinical practice:

radiologic characteristics on the plain chest radiograph

A pictorial review

\section{Chapter 6}

Diagnostic performance of the chest radiograph and the chest-CT in the detection of lung cancer: A review

Submitted.

Chapter 7

General discussion

Chapter 8

Summary and conclusions

Summary in Dutch

Acknowledgments

Curriculum Vitae 
The main results of this thesis are reported in the following papers:

Chapter 2 Miss rate of Lung Cancer on the Chest Radiograph in Clinical Practice. Chest 1999; 115: 720-724.

Gemiste longcarcinomen op de thoraxfoto in de klinische praktijk. Samenvatting. Nederlands Tijdschrift voor Geneeskunde 1999; 143: 2223 (Abstract).

Chapter 3 Detection of Lung Cancer on the Chest Radiograph: a Study on Observer Performance.

Accepted for publication in European Journal of Radiology.

De detectie van het longcarcinoom op de thoraxfoto: een onderzoek naar de validiteit en de consistentie van waarnemers. Samenvatting. Nederlands Tijdschrift voor Geneeskunde 2000; 144: 683 (Abstract).

Chapter 4 Detection of Lung Cancer on the Chest Radiograph: Impact of Previous Films, Clinical Information, Double Reading and Dual Reading. Accepted for publication in Journal of Clinical Epidemiology.

Chapter 6 Diagnostic Performance of the Chest Radiograph and the Chest-CT in the Detection of Lung Carcinoma. A Review. Submitted. 


\section{Chapter 1}

\subsection{General introduction}

\section{Epidemiology}

Lung cancer is the most common cancer in the world according to a study of Parkin et al. ${ }^{1}$ with an estimated rate of 896,000 new cases a year worldwide. In the United States, lung cancer is the leading cause of cancer related deaths for both men and women. ${ }^{2}$ It currently accounts for $33 \%$ of deaths from cancers in males and $24 \%$ of cancer deaths in women in the United States. ${ }^{3}$

In the Netherlands each year in about 9500 patients ( 8200 male and 1300 female) lung cancer will be diagnosed and almost 8500 patients die of lung cancer each year, 7500 malles and 1000 females. ${ }^{4}$

The incidence of lung cancer in males is declining but in females, however, there is a marked increase for all histological types. ${ }^{4}$

In the Middle and Southern part of the province of Limburg in the Netherlands, where this study took place, lung cancer was the most common tumor in men and took the third place in women. The incidence rate of lung cancer in males was 104.4/100,000, in females 17.4/100,000. Compared to other countries in Europe the incidence in men was very high, in women average.

Carcinoma of the lung is most closely associated with tobacco smoking and approximately $90 \%$ of male deaths were rellated to this cause. ${ }^{7}$ Even passive smoking increases the risk of developing lung cancer ${ }^{8}$ The increasing incidence of lung cancer in women is undoubtedly caused primarily by an increasing prevalence of cigarette smoking in women, ${ }^{9}$ expected to surpass those rates for men by the year 2000 .

\section{Histopathology}

According to the histological criteria of the $\mathrm{WHO}^{10}$ classification for lung cancer, the most frequent types of lung cancer are squamous cell carcinoma ( $39 \%$ ). adenocarcinoma (16\%), large cell carcinoma (10\%), adenosquamous carcinoma $(15 \%)$ and small cell carcinoma (20\%). The first four types are often classified as non-small cell lung cancer (NSCLC), accounting for $80 \%$ of all lung cancers. The most relevant difference from a clinical point of view between SCLC and NSCLC is the difference in prognosis and treatment. This is also true for the radiological presentation, since SCLC grows rapidly with early and widespread dissemination, especially massive mediastinal or hilar lymphadenopathy, which is very often the case at the time of initial diagnosis. "Because of this, surgery is not possible and the patients are treated mainly by chemotherapy. The patients with NSCLC, however, are, if the disease is detected at an early stage, good candidates for curative surgical therapy, especially if lymphnode metastases are absent, these patients are good candidates for curation.

\section{Staging, therapy and prognosis}

Accurate staging is important in the evaluation of patients with lung cancer with regard to therapy and prognosis. The prognosis is mainly dependent on the 
anatomical extent of the disease (TNM classification), the cell type, the patients condition and the possible therapeutic options. The new TNM classification, adopted in $1987^{\text {i. }}$ is now generally accepted, describing the primary tumor characteristics and its complications ( $T$ descriptor), if and to what extent regional lymph node metastases (N descriptor) and or distant metastases (M descriptor) are present (Table 1).

The radiologist's role is to diagnose lung abnormalities suspected for cancer and to estimate the anatomical extent of disease in relation to the TNM system. In patients with lung cancer (NSCLC and SCLC) one of eight individuals will have a 5 year survival. ${ }^{3}$ In symptomatic patients prognosis is poor because specific complaints or symptoms occur late in the disease and the prognosis in advanced lung cancer has. not changed significantly during recent decades. The prognosis is better if the diagnosis is made early when the disease is local and resectable radically with surgery. Approximately $70 \%$ of the stage 1 patients (Table 1) who were treated surgically had a survival of more than 5 years ${ }^{13-14}$ whereas approximately 83 to $97 \%$ of those patients who did not have surgery died within 5 years $^{13.15}$. The 5 year cumulative survivall is about $10 \%$, for surgical patients $20-25 \%{ }^{4}$ The best survival rate is achieved by those patients with asymptomatic solitary pulmonary lesions, most often detected on chest radiographs obtained for other indications. For this reason frequent screening for lung cancer with mass radiography and sputurn cytology was expected to improve the prognosis. ${ }^{13}$

\section{The radiology of lung carcinoma}

Each of the four types of non small cell lung cancers have more or less unique features and behavior patterns, often visible on the chest radiograph. The squamous cell carcinoma presents itself most commonly as a central mass. Adenocarcinomas and large cell carcinomas presents themselves most frequently as peripheral nodules. Forty to $60 \%$ of tumors are peripheral at presentation with a 6 to 4 ratio of involvement of the right versus the left lung with the upper lobes most frequently involved. ${ }^{16-17}$ Squamous cell carcinoma arises in central bronchi in over $65 \%$ of cases as an ill-defined hilar mass and therefore secondary signs of obstruction in the form of atelectasis and recurring post obstruction pneumonitis without an air bronchogram are often seen. In 35 to $40 \%$ the lesions are peripheral in location, often very large. poorly defined or have lobulated contours and are frequently cavitating. ${ }^{\text {is }}$

Adenocarcinoma presents as a peripheral mass on the chest radiograph in 60 to $70 \%$ of cases, round or oval in shape with a size often less than $4 \mathrm{~cm}$. A corona radiata or sunburst or a tail of tissue extending to the pleural surface is frequently present and is suggestive of malignancy. Adenocarcinoma has long been associated with parenchymal scars and eccentric calcifications. It is generally accepted that a lesion that has remained unchanged in size for over 2 years is most likely to be benign. ${ }^{18}$

Large cell carcinomas constitute about $15 \%$ of all lung cancers, and are radiographically often similai to adenocarcinomas. They are rapidly growing, often larger than $4 \mathrm{~cm}$ and peripherally located in $70 \%$ of patients.

Adenosquamous carcinomas represent 1 to $3 \%$ of all lung cancers and behave like adenocarcinomas. ${ }^{18}$ 
Table 1 TNM staging system for lung cancer.

\begin{tabular}{|c|c|}
\hline Stage & TNM Sub \\
\hline 0 & Carcinom \\
\hline $1 \mathrm{~A}$ & TI NOMO \\
\hline $1 B$ & $\mathrm{~T} 2 \mathrm{NO} \mathrm{MO}$ \\
\hline $2 A$ & $T 1 \mathbb{N} 1 M O$ \\
\hline $2 \mathrm{~B}$ & $\begin{array}{l}\text { T2 N1 MO } \\
\text { T3 NO MO }\end{array}$ \\
\hline $3 \mathrm{~A}$ & $T 3 N 1 M O$ \\
\hline & T1 N2 MO \\
\hline & T2 N2 MO \\
\hline & T3 N2 MO \\
\hline $3 \mathrm{~B}$ & TA NO MO \\
\hline & TA N1 MO \\
\hline & T4 N2 MO \\
\hline & T1 N3 MO \\
\hline & $\begin{array}{l}\text { T2 N3 MIO } \\
\text { T3 N3 MIO }\end{array}$ \\
\hline & T4 N3 MO \\
\hline
\end{tabular}

4

\section{T Descriptor}

Tx

To

TIS

T1

T2

T3

T4

\section{N Descriptor}
Nx
No
N1
$\mathrm{N}_{2}$
N3

\section{Descriptor}

Mx

MO

M1

\section{Any TAny N M1}

\section{Primary tumor}

Malignant cells in secretions, no tumor assessed

No evidence of primary tumor

Carcinoma in situ

Tumor $3 \mathrm{~cm}$ or less, no invasion proximal to lobar bronchus, surrounded by lung or visceral pleura

Tumor with any of the following features:

- More than $3 \mathrm{~cm}$ in greatest dimension

- Involves the main bronchus, $2 \mathrm{~cm}$ or more distal to main carina

- Invades the visceral pleura

Atelectasis or obstructive pneumonitis extending to hilar region but does not involve the entire lung

Tumor involving chest wall, diaphragm, mediastinal pleura, pericardium: or tumor in main bronchus less than $2 \mathrm{~cm}$ distal to carina but without involvement of the carina or atelectasis or obstruction poneumonitis of the entire lung Tumor invading: mediastinum, heart, great vessels, trachea, oesophagus, vertebral body, carina, or with malignant pleural effusion, or satellite tumor nodule(s) within the ipsilateral primary-tumor lobe of the lung.

\section{Regional Lymph Nodes}

Regional limph nodes cannot be assessed

No regional lymph node metastases

Metastases to ipsilateral peribronchial and/or ipsilateral hilar tymph nodes, and intrapulmonary nodes involved by direct exlension of the primary tumor. Metastases to ipsilateral mediastinal lymph nodes, including subcarinal. Metastases to contralateral mediastinal, contraliateral hilar, ipsilateral or contralateral scalene or supraclavicular lymph nodes(s).

Presence of distant metastasis cannot be alssessed

No distant metastases.

Distant metastases 


\subsection{Aim of the study}

Detection of lung cancer on the chest radiographs: problems and limitations The radiological manifestations of lung cancer are numerous and vary widely. When lung cancer is presenting itself as a small solitary pulmonary nodule on the chest radiograph, the differential diagnosis is extensive. This differential diagnosis includes granulomas, metastasis, hamartomas, pleural masses, fluid in interlobar fissures, haematomas, fungus balls, nipples etc. It appears that most nodules are benign. ${ }^{\text {is }}$ Unusual radiographic manifestations of lung cancer on the chest radiograph may elect other diagnosis. Pitfalls in the radiological diagnosis of lung cancer are many and can be grouped in three categories: First; errors in the detection of subtle lung cancers: Second; errors in the analysis of solitary pulmonary nodules, including miscalculation of the growth of nodules and Third; lack of familiarity with uncommon manifestations. ${ }^{20}$ There are a number of problems in the detection of subtle lung cancers including inadequate search (duration), (un) intentional under reading, lack of contrast difference between the lesion and the surrounding areas, image noise, superposing structures and complexity of the area surrounding the lesion, size, shape and improper viewing conditions. ${ }^{21-24}$

The exact error rate for the detection of early lung carcinoma on the chest radiograph in the literature varies widely, between $20 \%$ and $90 \%{ }^{25-28}$ However, these studies differ greatly in their design and purpose: lung cancer screening studies are showing the highest error rates. The accepted error rate in the literature is 20 to $30 \%$. To our knowledge, an exact miss rate in the detection of lung carcinoma on the chest radiograph in daily clinical practice has never been studied thoroughly. So that the first aim of our investigation was to study how many early lung cancers were detected and how many were missed on chest radiography in daily clinical practice.

\section{Observer performance in the interpretation of chest radiographs}

Another problem in the interpretation of chest radiographs is disagreement between different observers. In the literature, numerous studies have been performed to investigate the inter-and intra-observer variation in the interpretation of various pathological conditions on the chest radiograph. ${ }^{29-32}$ However no studies have been performed to investigate the observer performance in the detection of early lung cancer on the chest radiograph.

To improve the detection of pathological conditions on the (chest) radiograph and to improve the observer performance, not only is training of the observers an important tool, but also providing any previous radiographs for comparison and providing clinical information. ${ }^{33-34}$ Mammography screening studies showed that two observers, independently reading the radiographs, the so-called "double reading" can improve detection of early stages of cancer. ${ }^{35-36}$ in one study, interpreting chest radiographs by double reading ${ }^{37}$ an improvement in performance was observed. The impact of clinical information, previous chest radiographs and double reading in the detection of lung cancer on the chest radiograph has not been studied thoroughly previously. In this study the effect of these parameters on the observer performance was investigated.

\section{Role of screening in the early detection of lung carcinoma}

Large screening studies in the United States ${ }^{38-40}$ and Czechoslovakia" ${ }^{41}$ have been performed to investigate whether screening high risk groups (cigarette smokers) reduces the mortality of lung cancer and improves survival rate. These studies showed an increase of the incidence of lung cancer with an improvement in stage distribution, resulting in an increased resection rate and an improvement in survival rate at short notice, but ultimately there was no significant reduction in mortality. 
Because of these results, the role of the chest radiograph as a screening tool for the early detection of lung carcinoma is still controversial in the literature. In two screening studies, 39 . however, long term survival was observed, suggesting that cure rates could improve from approximately $13 \%$ to $33-35 \%$ in the context of periodic screening. ${ }^{2}$ In a recent study investigating the prognosis in patients with lung cancer found on a single chest radiograph screening ${ }^{43}$ the survival rate of men in the screened cases remained significantly higher than that of men in other (control) cases. In the recent literature ${ }^{42-44}$ ) there has been a reconsideration of the role of chest radiographs in screening for early detection of lung cancer.

\section{Plain chest radiographs or CT as a tool for screening for early carcinoma of the lung?}

The radiological evaluation of the patient with suspected lung cancer includes chest radiographs and is most often followed by performing a computed tomography (CT). A computed tomography is generally performed for further evaluation of the suspected abnormalities seen on the chest radiographs as well as for detection when the lesion is not visible on the chest radiograph. Furthermore CT is used for characterization of lesions and for staging of the disease. It is well known that CT has advantages over the conventional chest radiograph in detection of early stages of lung cancer. Most of the lesions which were missed on the chest radiographs but detected on chest CT were small tumors that were superimposed on normal chest structures (e.g. ribs, costal cartilage, mediastinum, pulmonary vessels): CT eliminates superposition. Chest $\mathrm{CT}$ has a better density resolution than the chest radiograph and therefore small and faint lesions are detected earlier. The tumor detection rate of chest CT was 1.4 times higher. ${ }^{45-43}$ The higher sensitivity of CT with regard to the chest $x$-ray is necessary to get a better outcome in screening, resulting in a higher survival rate. Because of this presumption, CT is now under investigation in order to establish its role in the detection and screening of lung cancer ${ }^{47-49}$ Therefore, the third aim of this study was to review the literature to find out what is already known about the performance of chest $\mathrm{CT}$ in relation to the chest radiograph in the detection of lung cancer.

In summary the aims of these thesis were,

1. To study the miss rate of lung cancer on the chest radiograph in daily clinical practice.

2. To study the characteristics of missed lung cancers and to compare them with the characteristics of the detected neoplasms.

3. To estimate the influence of the delay in diagnosis in patients with missed lung carcinoma on the chest radiograph on the survival rate.

4. To study the inter-and intra abserver variability in the detection of lung cancer on the chest radiograph.

5. To study the impact of clinical information and availability of previous radiographs in the detection of lung carcinoma on the chest radiograph.

6. To study the impact of double reading and dual reading on the detection of early lung cancer.

7. To study in the literature the role of spiral CT in the detection of early lung cancer.

\subsection{Description of the study material and patients}

The study was carried out between 1995 and 1999 in the Atrium Medical Center Heerlen, the Netherlands. From January 1992 to January 1996 all consecutive patients with histopathologically proven NSCLC presenting in the Center were included. These patients were traced by use of the data base of the Dutch National 
Pathological Anatomical Cancer Registration System (PALGA). Patients with recurrent cancer after therapy were excluded. All available chest radiographs were collected from all these patients and reviewed by fwo radiologists independently. The decision whether or not a lesion was present was made by consensus between these two radiologists. If a visible lesion was not mentioned in the original radiological report, it was considered to have been missed. A third radiologist, blinded for the location of the lesion, reviewed the radiographs once again and after consensus with the first two viewers the definitive decision whether a lesion had or had not been missed was made.

In chapter 2 data on the miss rate of lung cancer on the chest radiograph in clinical practice is presented. The impact of the miss rate on prognosis is calculated and an analysis is given of the most frequent causes of missing a lesion.

To study the variability of observers performance, 30 out of a set of 49 chest radiographs with lesions which were visible but had been missed in daily clinical practice (as described in chapter 2 ), were selected. For all these selected cases the posterior-anterior and lateral chest radiographs had to be available and of good quality. Also the lesions had to be unequivocally visible as determined by consensus between three radiologists. The radiographs of the selected cases were interiningled in a random order with radiographs of 35 patients with normal chest radiographs and with radiographs of another 35 patients with pathological conditions other than lung cancer. All these chest radiographs were presented to a group of 14 observers who consisted of 10 radiologists, 2 chest physicians (all with more than ten years of clinical experience) and two residents in radiology in their 4 th year of training. All observers, who were unaware of the purpose of the study, scored their findings on a pre arranged check list. The inter observer variability was calculated using the kappa statistics. Four months after this study, a second session was held in the same way with the same study material but in a different random order with 7 observers consisting of 5 radiologists, one chest physician and one resident in radiology. The intra observer variability was calculated with use of the results of both sessions. Variability in sensitivity, specificity and odds ratio were calculated for each observer. The results of this study is presented in chapter 3.

The second group ( 7 observers consisting of 5 radiologists, one chest physician and one resident in radiology) participated in another study presented in chapter 4.

These observers reviewed all 100 cases again, with provision of clinical information (suspicion of malignancy) and previous chest radiographs. The changes of the sensitivity, specificity and diagnostic odds ratio, compared to those of the first viewing session was calculated.

Eight months after these sessions a third session was heid. In this session the possible benefits of double reading and dual reading were investigated. Dual reading of the 100 chest radiographs used in the foregoing studies was done by four pairs of observers viewing the radiographs simultaneously. These results were compared with the results of the single reading of these observers, done in the first study session (chapter 3 ). The results of these four couples (of the individual reading) out of the first study session were paired resulting in double reading. Sensitivity and specificity of single-, dual- and double reading were calculated as well as the changes of the diagnostic odds ratio in dual- and double reading in relation with the odds ratio of single reading. The results of this study are also presented in chapter 4. In chapter 5 the radiological characteristics of the missed lung cancers on the plain chest radiographs are described. The chest radiographs of patients with missed lung cancer were obtained from the patient population described above in chapter 2 . Out of 380 patients with carcinoma of the lung, 259 presented with a nodular lesion on the chest radiograph. Out of these 259 cases, after consensus by three radiologists, it was decided that in 49 patients the lesion happened to be missed on the chest 
radiograph in clinical practice by the radiologist. The radiological characteristics of all these 49 missed lung carcinomas on the chest radiographs were analyzed, described and categorized. Of each group of characteristic features of a missed lesion, an example is given by a photograph of a chest radiograph with such lesion on it. In chapter 6 the results of a review is presented on the performance of the chest radiograph and chest computed tomography (CT) in the detection off lung cancer. All English language articles published since 1980 for chest radiographs and since 1985 for chest CT were searched for diagnostic accuracy. These studies had to be original work and histology, cytology or an appropriate follow up period had to be used as the standard of reference. The study characteristics of each study were described and a distinction was made between studles evaluating the diagnostic accuracy of the plain chest radiograph, those evaluating CT of the chest and studies evaluating both chest radiographs and chest CT. For all these studies, prevalence, sensitivity, specificity, positive- and negative predictive values in the detection of lung cancer were calculated.

In chapter 7 the results of the studies described in chapter 2-6 will be summarized and commented on. In chapter 8 a final conclusion will be generated from all studies and recommendations will be made for further investigations.

\section{References}

1. Parkin DM. Pisani P. Ferlay $\Downarrow$. Estimates of the worldwide incidence of eighteen major cancers in 1985. Int J Cancer 1993; 54:594-606.

2. Landis SH, Murray T, Bolden $\mathrm{S}$, et al. Cancer statistics, 1997. Cancer J Clin 1997; 48:6-29.

3. Wingo P. Tong T, Bolden S. Cancer Statistics 1995. Cancer" J Clin 1995; 45: 8m 31.

4. Coeberh JW. Incidence and prognosis of cancer in the Netherlands: studies based on cancer registries, (dissertation). Rotterdam, Unwersity of Rotterdam 1991: 131-144.

5. Schouten LJ, De Rijke JM, Huveneers. JAM, Jager JJ, Brandt van den PA. 10 year cancer incidence in mid and south Limburg 1986-1995. Maastricht Cancer Registry. Integraal Kankercentrum Limburg 1998: 24-26.

6. Fry WA, Menck HR, Winchester DP. The National Cancer Data Base Report on Lung Cancer. Cancer 1996; 77: 1947-1955.

7. Stevens RG, Moolgavleer SH. A cohort analysis of lung cancer and smoking in British males Am .J Epidemial 1984; 19:624.

8. Janerich DT, Thompson WD. Varela LR, et al. Lung cancer and exposure to tobacco smake in the household. N Engl J Med 1990; 323: 632-636.

9. Baldini EH, Strauss GM. Woman and Lung Cancer. Waiting to Exhale. Chest $1997 ; 112$ 229s-234s

10. The World Health Organisation mistological typing of lung tumots. Am $J$ Clin Pathol 1982; 77 $123-136$.

H1. Bergsagel D, Feld R. Small cell lung cancer is still a problem (editorial). J Clin Oncol 1984; 2 $1189-1191$

12. Mountain CF. Revision im the intermational System for Staging Lung Cancer. Chest 1997; 111 $1710-1717$

13. Flehinger BJ, Kimmel M, Melamed MR. The Effect of Surgical Treatment on Survival from Early Lung Cancer. Implications fior Screening. Chest 1992; 101: 1013-1018.

4. Naruke $T$, Tsuxhya $R$. Kondo $H$, Asamura $H$. Nakayama $H$. Implications of Staging in Lung Cancer. Chest 1997; 112:242s-248s.

15. Sobue T, Susuki T, Maitsuda M, Kuroishil T, lkeda S, Naruke T. Survival for Clinical Stage 1 Lung Cancer Not Surgicaly Treated. Comparison Between Screen-Detected and Symptom -Detected Cases. Cancer 1992:69:685-692.

16. Parc JAP. Fraser RG: Synopsis of diseases of the chest. Philadelphia, WB Saunders 1983: 405.

17. Woodring $\mathrm{JH}$, Stelling $\mathrm{CB}$. Adenocarcinoma of the lung: A tumor with a changing pleomorphic character. A JR 1983; 1.40:657-664.

18. Sider L. Radiographic Manifestations of Primary Bronchogenic Carcinoma. Radiol Clin of North Am $1990 ; 28: 583-597$.

19. Ray JF, Lawton BR. Magnin GE el al. The coin lesion story: update 1976. Twenty years experience with early tharacotomy for 179 suspected malignant coin lesions. Chest 1976 ; 70 . 332-336.

20. Woodring JH. Pitfalls in the Radiologic Diagnosis of Lung Cancer. A.JR 1990; 154:1165-1175 
21. Swens:on $\mathrm{RG}_{\text {, Hessel }} \mathrm{SJ}$. Heman PG. Omissions in radiology: fauty search or stringent reporting criteria? Radiology $1977 ; 123 ; 563-567$

22. Kundel HL. Predictive value and threshold detectability of lumg humors. Radiology $1981 ; 139$ $25-29$.

23. Kundel HL. Nodine CF. Krupinski EA. Searching for lung nodules: visual dwell indicates locations of false positive and false regative decisions. Invest. Radiol $1989,24: 472$ - 478 .

24. Revesiz $\mathrm{C}$, Kundel HL. Pychophysical studies of detection errors in chest radiology. Radiology $1977 ; 123: 55 \%-562$

25. Stik FP, Tockman MS. Radiographic screening in the early detection of lung camcer. Radiol Chin of North Am 1978: 16:347-366.

26. Heelan RT, Flehinger B. Melamed MR, et al. Non-small-cell lung cancer; results of the New York screening program. Radiology 1984; 151: 289-293.

27. Muhm JR Miller WE, Fontana RS, et al. Lung cancer detected during a screening program using four-montlu chest radiographs. Radiology $1983 ; 148: 609-615$

28. Guis LW, Kuenstler. A retrospective review of survey photofluorograms of persons with lung cancer. Cancer 1960; $13: 91.95$

29. Heman $P G$. Gerson DE, Hessel S.J al Disagreements in chest roentgen interpretation. Chest $1975 ; 68: 278 ; 282$

30. Young M. Marrie T. Interobserver variabilly in the interpretation of chest roentgenograms of patients with possible pneumonia. Arch Intern Med 1994" 154:2729-2732

31. Tudor GR. Finlay D. Taub N. An assessment of inter-obsenver agreement and accuracy when reporting plain radhographs. Clin Radiol 1997; $92: 235.238$

32. Yerusaimy $J$. The statistical assessment of the variability in observer perception and description of the roentgenographic pulmonary shadows. Radiol Clin of North Am 19169; 7: $381 \times 392$.

33. Doubilet $P_{\text {}}$ Herman $\mathrm{PG}$. Interpretation of radiographs: Effect of clinical history. AJR 1981: 137 : $1055-1058$

34. Berbaum KS, Franken EA, Darfiman DP, et al. Influence of clinical history on perceptions of abnormalties in pediatric radiographs. Acad Radiol 1994; $1: 217 \times 223$

35. Thurfell EL, Lernevall KA, Taube AAS. Benefit of independent double reading in a population based mammography screening program. Radiology 1994; 191: 241-244.

36. Andersorn EDC. Muir BB. Waish $\mathrm{JS}_{\text {, }}$ et all. The efficacy of double reading mammograms in breast screening. Clin Radiol 1994; 49: 248-251.

37. Hessel SJ, Herman RG, Swensson RG. Improving performance by multiple interpretations of chest radiographs: Effectiveness and costs. Radiology 1978; 127: $589-594$.

38. Frost JB, Ball WC, Levin ML, et al. Early Lung Cancer Detection: Results of the Initial (Prevalence) Radiologic and Cytologic Screening in The John Hopkins Situdy. Am Rev Respir Dis 1984; 130 ; $549-554$

39. Flehinger BJ, Melamed MR, Zaman MB, et al. Early Lung Cancer Detection: Results of the initial (Prevallence) Radiologic and Cytologic Screening in the Memorial Sloam-Kettering Study. Am Rev Respir Dis 1984: 130: 555-560.

40. Fontana RS, Sanderson DR, Taylor MF, et al. Early Lung Cancer Detection: Results of the Initial (Prevalence) Radiologic and Cytologic Screening In the Mayo Clinic Study. Am Rev Respir Dis $1984: 130 ; 564-565$.

41. Kubic A, Polak J. Lung Cancer Detection. Results of a Randomized Prospective Study in Czachoslovakia. Cancer 1986; 57:2427-2437.

42. Stranss GM. Measuring Effectiveness of Lung Cancer Screening. From Consensus to Controversy and Back Chest 1997; 112:216s-228s.

43. Salomari ER, Lippo K, Taylor P, et all. Prognosis of patients with lung cancer found in a single chest radiograph screening. Chest $1998 ; 114 ; 1514-1548$.

44. Strauss GM, Glearson RE, Sugarbaker DJ. Chest $X$-ray Screening Improves Outcome in Lung Cancer. A Reappraisal of Randomized Trail on Lung Cancer Screening. Chest 1995; 107 : $270 \mathrm{~s} \cdot 279 \mathrm{~s}$.

45. Mori K. Tominagla K. Hirose T, et al. Utility of Low-Dose Helical CT as a Second Step After Plain Chest Radiography for Mass Screening for Lung Cancer. J Thorac Imag. 1997; 12: 173-180.

46. Ohimatsu H, Eguchi K, Kameko M. Hirano H. Moriyama N. Feasibility study of helical-volume CT for the detection of peripheral lung nodules. Radiology $1992 ; 185: 353$.

47. Kaneko $M$. Eguchi $K_{1}$ Ohmatsu $H$ et al. Peripheral Lung Cancer: Screening and Detection with Low-Dose Spinall CT versus Radiography. Radiolagy 1996; 201:798-802.

48. Henschke CJ, Mc Cauley DJ, Yankelevitz DF, et al. Early Lung Cancer Action Project: overall design and findings from baselime screening. The Lancet 1999; 354: 99-105.

49. Sone $S$, Takashima $S$, Li F, et al. Mass screening for lung cancer with mobille spiral computed tomography scanner. The Lancet $1998 ; 351: 1242-1245$. 


\section{Chapter 2}

\section{Miss rate of lung cancer on the chest radiograph in clinical practice*}

Quekel LGBA, Goei R, Kessels AGH, van Engelshoven JMA

Presented at the annual meeting of the Radiological Society of the Netherlands, Veldhoven 1998.

Abstract nominated for the Ernst Schering Award 1998.

Abstract published in: - Ned Tijdschr Geneeskd 1999; 143: 2223.

- The year Book of Pulmonary Disease 2000; chapter 3: 127128. 


\section{Abstract}

Study objectives To investigate the miss rate of non-small cell lung cancer (NSCLC)

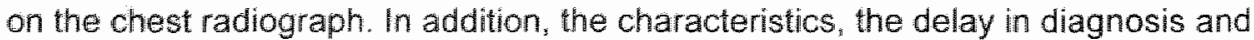
the change in prognosis of the missed lesions were studied.

Design A retrospective study on patients with histopathologically proven NSCLC during the years 1992 through 1995 in a large community haspital.

Setting Department of Radiology, Atrium Medical Center Heerlen, the Netherlands. Patients During the study period, 495 patients presented with NSCLC. Of these patients, the complete set of chest radiographs was available for analysis in 396 ; there were 300 men and 96 women, with mean age 68 years.

Main outcome measures The main outcome measures included the miss rate of NSCLC presenting as nodular lesions. Location, diameter, superposing structures, and delay of missed and detected lesions and the change of prognosis as a consequence of the delay in diagnosis were other measures.

Results In $49(19 \%)$ of 259 patients with NSCLC presenting as a nodular lesion on the chest radiographs, the lesions were missed. The miss rate was not dependent on location. Superposing structures were more often present in the group of missed lesions than in the group of detected lesions, respectively, $71 \%$ and $2 \%$. The median diameter of the missed lesions was $16 \mathrm{~mm}$ and of the detected lesions $40 \mathrm{~mm}$. The median dellay of the missed lesions was 472 days and of the detected lesions it was 29 days. Twenty-two $(45 \%)$ patients with missed lesions remained in the stage T1, 6 $(12 \%)$ remained in the stage T2 and in 21 patients (43\%), the tumor stage changed from stage $\mathrm{T} 1$ into $\mathrm{T} 2$.

Conclusion The miss rate of $19 \%$ in our study is low compared with the rate in the literature but it has a definitive impact on prognosis.

Key words diagnostic errors, lung neoplasims, thoracic radiography. 


\section{Introduction}

The diagnosis of early non-small cell lung: cancer (NSCLC) on the chest raciograph may be troublesome. Many lung cancers present themselves as small solitary nodules. Failure to detect lung cancer on the chest radiograph, which has become one of the most frequent causes of missed diagnosis in radiology." ${ }^{1.3}$ is a major cause of medicolegal action.

Small pulmonary nodules are often missed because of poor lesion conspicuity caused by superimposition of hilar and mediastinal structures, blood vessels, clavicles or ribs. Poor viewing conditions and poor technical quality of the images are also reasons why small lesions can be missed. ${ }^{4-9}$

In the literature, the proportion of missed lung cancers on chest radiographs varied between $25 \%$ and $90 \%{ }^{40.42}$ However, these studies differ largely in study design. Some were designed to measure the miss rate of solitary pulmonary nodules in general rather than lung cancer. Other studies were laboratory studies that investigated different parameters influencing failure to detect small pulmonary lesions. Other investigators studied small selected groups of patients. Furthermore, some studies presented data resulting from screening programs to detect early lung cancer in high-risk patients. Thus, the exact miss rate in the detection of early lung cancer on the chest radiograph is difficult to estimate.

The generally accepted error rate for the radiologic detection of early lung cancer is between $20 \%$ and $50 \%{ }^{13}$

The purpose of the present investigation was to determine the miss rate of the detection of early lung cancer on the chest radiograph in the daily routine of a radiology department of a large community hospital. In addition the characteristics and distribution of these missed cancers were compared with those of the detected cancers. Finally, the delay in diagnosis was determined as well as an estimate of the consequence for the prognosis thereof.

\section{Materials and methods}

The study included all consecutive patients with pathologically proven NSCLC selected from the database of the Dutch National Pathologic Anatomic Cancer Registration System between 1992 and 1995 in a 700 -bed communily hospital. Patients with recurrent cancer after therapy were excluded. The chest radiographs were obtained in the 125 - to $150-\mathrm{k}$ Vp range, grid ratio $12: 1$, focus film distance 150 $\mathrm{cm}$, rare earth screen with speed class 400 (Agfa ortho regular or Agfa curix HT-U films; Agfa Gevaert, Mortsel "Belgium). All available chest radiographs (posterioranterior and lateral) of these patients obtained before the day of the histopathological diagnosis, were included in the study.

Patients: age and gender as well as characteristics of the tumor on the chest radiography were recorded on a prearranged checklist. Furthermore, each lung cancer visible on the chest radiograph was classified as a nodular lesilon, focal area of airspace disease (ie, infiltrate), atelectasis, pleural fluid, or combinations of these characteristics.

The nodular lesions were localized as peripheral ( $23 \mathrm{~cm}$ distance from the hilus), parahilar ( $<3 \mathrm{~cm}$ from the hilus) or hilar and were also localized in a specific lung lobe. The margins of the lesions were characterized as sharp, partly sharp, or entirely unsharp. The visibility of the lesion on the posterior-anterior and lateral chest radiograph was scored on a three-point scale and any superposing structures were 
recorded. The largest diameter of each carcinoma was measured on the posterioranterior and/or lateral chest radiographs.

Whether a lesion was missed, was determined by the following procedure. Two radiologists independently scrutinized all available posterior-anterior and/or lateral chest radiographs of all patients on nodular lesions. The decision whether a lesion was visible was made by consensus between these two radiologists. The location of the lesion in the lung was confirmed by the histopathologic report, bronchoscopic finding or surgical report. If a lesion was not mentioned in the original radiological report, it was considered visible but not detected. A third radiologist from another institution who was aware of the study design but blinded for the location of the lesion, reviewed all radiographs of the patients with visible but not detected lesions as selected by the first two observers. In case the third observer did not locate the tumor, consensus with the first two observers clecided whether a lesion was definitely missed or not. It was also recorded whether a lesion was missed more than once. The delay was defined as the span of time between the date of the histopathological diagnosis and the date of the first radiograph on which the missed lesion was first detectable according to the consensus of the three radiologists. According to the revised American Joint Committee on Cancer staging system ${ }^{14}$ we divided the missed tumors as stage $T 1$ and $T 2$ : stage $T 1$ includes tumors with a diameter $\leq 30$ $\mathrm{mm}$ and stage $\mathrm{T} 2$ tumors with diameter $>30 \mathrm{~mm}$.

\section{Results}

From the Dutch National Pathologic Anatomic Cancer Registration System database, 495 consecutive patients from 1992 through 1995 with histopathological proven first detected NSCLCs were identified in our hospital. In 99 patients, the radiographs were not traceable.

The characteristics of the remaining 396 patients are presented in Table 1. In 36 patients more than one abnormality on the chest radiograph was visible.

Table 1. Characteristics of the study population.

Total number

Age, median (range)

Number of miales $(\%)$

Chest $X-r$ ay abormalities"

Alelectuses (\%)

Infillitates $(\%)$

Pleural fluid $(\%)$

Nodiular lesions $(\%)$

No abnormalities on chest $X$-ray $(\%)$

(small endobronchial tumors)

$\begin{aligned} & 396 \\ & 68(37-85) \\ & 300(75.8) \\ & 38(10) \\ & 57(14) \\ & 63(16) \\ & 259(65) \\ & 15(4)\end{aligned}$

* Percentages do not add up to $100 \%$ because several patients had more than one abnormalilly.

Two radiologists preselected 259 patients with visible lesions on the chest radiographs. In 60 patients, the NSCLC was visible but not detected on one or more consecutive chest radiographs. These NSCLCs were verified by the histopathological 
report. After examination by the third radiologist of the radiographs of these 60 patients, consensus among the three reviewers agreed that in 49 patients, the lesion was missed and in 11 patients, the lesion was visible but not detectable without additional information of the chest radiographs in an advanced stage of the tumor. Thus, in $49(19 \%)$ of the 259 patients with a nodular lesion, the lesion was definitely missed. In $16(33 \%)$ of the 49 patients, the lesion was missed twice on consecutive chest radiographs and in $6(12 \%)$ patients, the lesion was missed more than wice. Table 2 compares the demographic patient variables and the characteristics of the tumors between detected and missed lesions. Most of the lesions were located in the periphery of the lung $(56 \%)$ and in the upper lobes $(66 \%)$, but no significant difference in location between missed and detected lesions was found. Superposing structures were more frequently present in radiographs with missed lesions, the diameter of the lesion was smaller, and the clinical delay was longer. All these differences were statistically significant.

Table 2. Comparisoin of the characteristics of the missed and the detected malignant modular lesions.

\begin{tabular}{|c|c|c|c|}
\hline & $\begin{array}{l}\text { Missed } \\
\text { lesions }\end{array}$ & $\begin{array}{l}\text { Detected } \\
\text { lesions }\end{array}$ & $\begin{array}{l}\text { P-value } \\
\text { (2-tailed) }\end{array}$ \\
\hline Total number & 49 & 210 & \\
\hline Number of males $(\%)$ & $40(82)$ & $157(75)$ & $0.3^{\#}$ \\
\hline Age, median (range) & $71(48-88)$ & $68(37-87)$ & $0.02^{8}$ \\
\hline \multicolumn{4}{|l|}{ Location of nodular lesions" } \\
\hline hillar, No. $(\%)$ & $7(14)$ & $25(12)$ & $0.6^{\ddagger}$ \\
\hline parahilar, No. (\%) & $15(31)$ & $71(34)$ & $0.7^{*}$ \\
\hline peripheral No. $(\%)$ & $27(55)$ & $118(56)$ & $0.9^{4}$ \\
\hline Right Upper Lobe, No. (\%) & $21(43)$ & $70(33)$ & $0.2^{*}$ \\
\hline Left Upper Lobe, No. (\%) & $10(20)$ & $71(34)$ & $0.07^{\circ}$ \\
\hline Right Lower Lobe, No. $(\%)$ & $10(20)$ & $36(17)$ & $0.6^{*}$ \\
\hline Left Lower Lobe, No. (\%) & $8(16)$ & $28(13)$ & $0.6^{*}$ \\
\hline Right Middle Lobe No. (\%) & $-(0)$ & $12(6)$ & $0.13^{\pi}$ \\
\hline Lingula, No. $(\%)$ & $-(0)$ & $9(4)$ & $0.2^{11}$ \\
\hline superposing structures $(\%)$ & $35(71)$ & $4(2)$ & 0.0001 \\
\hline diameter in $\mathrm{mm}$, median (range) & $16(6-38)$ & $40(5-159)$ & $<0.0001^{5}$ \\
\hline Delay in days, median (range) & $472(7-3233)$ & $29(0-4148)$ & $<0.0001^{8}$ \\
\hline
\end{tabular}

" Wumbers do not add up to $210 ; 11$ patients had more than one lesion

\#:Chi-square test, " Mamn Whitney test," : Fisher's exact test

Compared with the detected tumors, the median diameter of the missed tumors is significantly smaller in all three regions (Table 3 ). Thirty-six of the 49 missed lesions $(73 \%)$ did not have sharp borders or only part of the border was sharp. Only 13 of the 49 missed lesions (27\%) had sharp borders.

In one patient the lesion was visible on the lateral chest radiograph only, but this lesion was missed.

Figure 1 shows a histogram of the diameter of the missed and detected lesions. Of the lesions $\leq 10 \mathrm{~mm}$, the miss rate was $71 \%$; between 10 and $30 \mathrm{~mm}, 28 \%$, and between 30 and $40 \mathrm{~mm}, 12 \%$. 
Table 3. Miss rate and comparison between the diameter of the missed and detected lesions stratified for location.

Hilar Parahilar Peripheral

$\begin{array}{llll}\text { Number } & & & \\ \quad \text { Detected lesions } & 23 & 71 & 116 \\ \text { Missed lesions } & 7 & 15 & 27 \\ \text { Miss rate } & 21 \% & 17 \% & 19 \% \\ \text { Median diameler (range) in mm } & & & \\ \text { Detected lesions } & 35(15-90) & 40(12-130) & 40(5-160) \\ \text { Missed lesions } & 27(11-32) & 17(9-37) & 13(1-38) \\ \text { Test" for difference } & p=0.025 & p<0.0001 & p<0.0001\end{array}$

i if more than one lesion was present, the location and dameter of the largest lesion was taken

* Mann-Whitney test

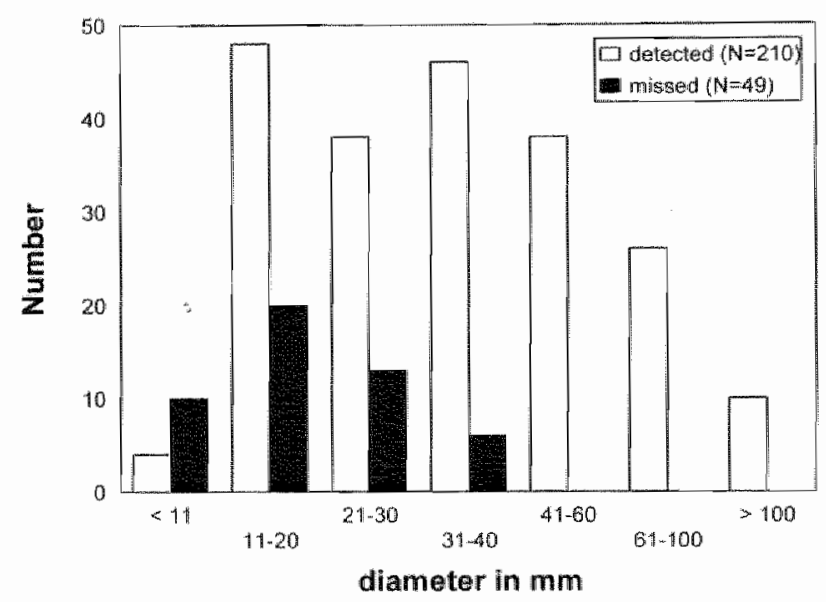

Figure 1 Bar graph demonstrates the diameters of the missed and detected lesions

The explanation for missing the tumors was diverse. Ten tumors had diameters of $\leq 10 \mathrm{~mm}$. In 27 patients, superposing structures were present: in 11 cases, the ribs sometimes with the clavicle or sternum; in 7 cases, the hilar structures; the vessels 5 times; advanced silicosis 2 times; and the heart and the diaphragm each one time. In two patients, a resolving infiltrate and a haematoma after a trauma were the reasons. In 9 of the remaining 10 patients, the tumor had a diameter between 11 and $14 \mathrm{~mm}$. In the 10th case, the diameter was $21 \mathrm{~mm}$ with no obvious reason for the missed diagnosis.

The delay in diagnosis in the 49 patients with missed NSCLC had a wide range. The number of patients with a delay $<6$ months, between 6 and 12 months, between 12 and 24 months, and $>24$ months was respectively, $12(24.5 \%), 9(18 \%), 16(33 \%)$, and $12(24.5 \%)$.

Figure 2 shows a scatterplot with the diameter when firstly missed on the $X$-axis and the diameter first detected on the $Y$-axis of the 49 missed tumors. In $28(57 \%)$, the 
tumor stage did not change despite the delay; 22 patients (45\%) remained in the T1 stage, and $6(12 \%)$ remained in the T2 stage. In 21 of the 49 patients (43\%), the tumor stage changed from T1 into T2.

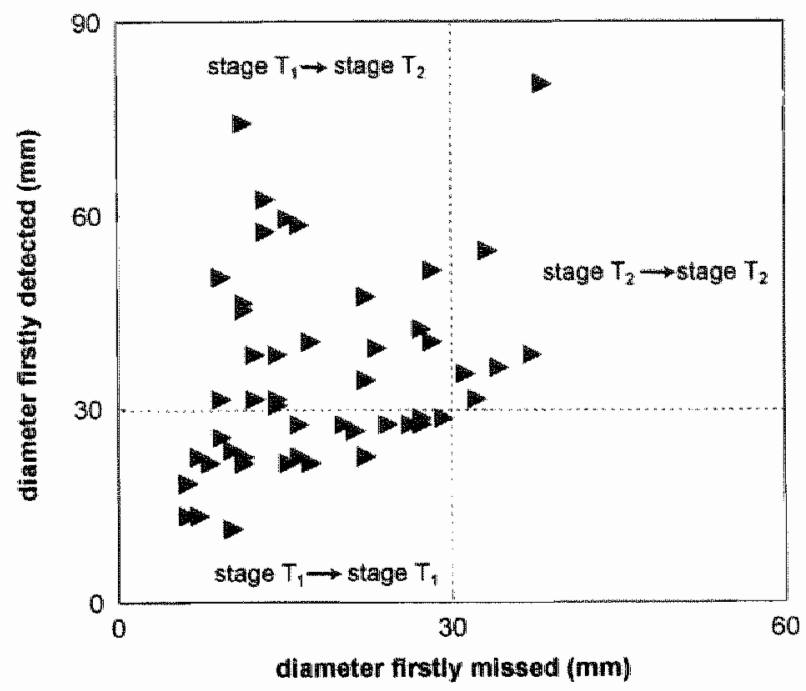

Figure 2 Graph showing the change in tumor stage of the missed cancers.

\section{Discussion}

To our knowledge, no studies have been reported that addressed the miss rate of the chest radiography in detecting lung cancer in clinical practice. In the literature, the miss rate of such lesions varied between $25 \%$ and $90 \%,{ }^{10-13}$ but as indicated in the introduction, these figures originate from studies that differ largely in objective and design. In our study, a miss rate of $19 \%$ was found.

In 99 of the 495 cases, a chest radiograph was not available for analysis. However, there was no indication that this was a selected group and we assume that our study population is representative. Furthermore, our population of 396 cases did not differ demographically from the cancer registration of the particular region: $:^{15}$ the percentage of men of the study population of our study was $76 \%$ vs $80 \%$ in the registry, and the median age in both populations was 68 years.

We found that in $65 \%$ of the studied cases, the tumors were visible as a nodular lesion on the chest radiograph; their diameter varied from $6 \mathrm{~mm}$ to $160 \mathrm{~mm}$ and was mostly in the range of $10 \mathrm{~mm}$ to $50 \mathrm{~mm}$ (Figure 2). The median diameter of the lesions was $30 \mathrm{~mm}$, which is comparable to those reported by other authors. ${ }^{11,12.16}$ In the study of Theros, ${ }^{16} 52 \%$ of the malignant nodular lesions were located peripherally and about $60 \%$ were in the upper lobes. Several authors ${ }^{8.9 .12,17}$ also reported a preference of missed lesions for the upper lobes. In this regard we found a preference of the upper lobes for the detected lesions as well as the missed lesions (Table 2). Some authors ${ }^{18-20}$ suggest that overlying anatomic structures, such as vessels, ribs, the heart etc, are far more important for missing a lesion, particularly small ones, than the location. In general, it is assumed that detection of hilar cancers is hampered by the wide variability of the hilar anatomy. In a screening 
program, Muhn et al ${ }^{2}$ found that $65 \%$ of the lung cancers arising in the hilum were missed. In this study, 7 of 32 hilar lesions (22\%) were missed and, surprisingly, no substantial differences in miss rates among the peripheral, parahilar, and hilar regions (Table 3 ) were found.

The diameters of the missed lesions located peripherally or in parahilar region are significantly smaller than those of the detected lesions (Table 3). Centrally located lesions that are missed are larger than peripherally located lesions.

In our study, the median diameter of a missed lesion was $16 \mathrm{~mm}$ (range, 6 to 38 mm). Heelan et al, ${ }^{11}$ in a screening program, and Austin et al ${ }^{8}$ in a series of 27 patients, found mean diameters of missed lesions of respectively, 13 and $16 \mathrm{~mm}$. However, some authors ${ }^{6} \cdot 16$ state that on a good-quality chest radiograph, a nodule of 3 to $4 \mathrm{~mm}$ is the smallest lesion that can be detected. In two studies ${ }^{5,7}$ with lesions of 8 to $10 \mathrm{~mm}$ in size, detection rates of $40 \%$ and $87 \%$ were found. In the present study, a detection rate of $29 \%$ in lesions $\leq 10 \mathrm{~mm}$ in diameter was found. In lesions $>10 \mathrm{~mm}$, the miss rate drops promptly and lesions $>40 \mathrm{~mm}$ were not missed (Figure 2).

The detection probability is strongly related to the blur or unsharpness of the edges of pulmonary nodules. Kundel et a ${ }^{2: 1}$ have shown that detection probability can fall from almost $90 \%$ in sharply bordered to $30 \%$ in unsharply bordered lesions. Austin et al $^{6}$ found that $95 \%$ of the missed lesions was unsharply bordered. in our series, $73 \%$ of the missed lesions were partly or totally unsharply bordered.

In our study in six patients, the lesion was missed more than two times in the same patient. In two of these patients, the lesion showed hardly any growth in several years. The radiologist did not describe the lesion, probably presuming that it concerned a non-malignant scar lesion. This would also explain the long delay. The other four cases were slowly growing tumors and were missed a few times in succession.

Different opinions exist about the necessity of performing posterior-anterior and lateral chest radiographs at all times. Tala ${ }^{22}$ stated that a lateral radiograph is decisive in $20 \%$ of the patients for diagnosing lung cancer. Other authors ${ }^{8,10,12}$ found 3 to $4 \%$ of the lung cancers only on the lateral chest radiographs. Forrest and Sage ${ }^{23}$ found all NSCLC visible on posterior-anterior chest radiographs, suggesting that lateral chest radiographs is superfluous for detection. In our study, one lesion was visible only on the lateral radiograph and this lesion was missed. We think that both the posterior-anterior and lateral chest radiographs are necessary for determining the exact location of the tumor but not for detecting it.

The reasons for missing the lesions were the small size $(<15 \mathrm{~mm})$ and superposing structures. In one lesion with a diameter of $21 \mathrm{~mm}$, there was no apparent explanation for not detecting. Therefore, we think a miss rate of $19 \%$ as found in our study is realistic and difficult to improve. This is also suggested by the generally accepted miss rate of 20 to $50 \%$ as reported in the literature. $10-13$

Prognosis is influenced by the growth of the tumor and thus dependent on the length of the delay time. There is a wide variability of the interval between the actual detection of lung cancer on the chest radiographs and its retrospective presence. 9.11 .12 In the study of Forrest and Friedman, ${ }^{9}$ in 15 of 27 patients with radiologically missed lung cancers, the time from the first radiological appearance to the first diagnosis was $>6$ months and in two instances it was $>3$ years. In our study, $75 \%$ of the patients with missed lung cancers had a delay of $>6$ months and eight patients had even $>3$ years. 
In 28 patients $(57 \%)$, the tumor stage did not change and in 21 patients $(43 \%)$, the tumor stage changed from T1 to T2 (Figure 1). According to Mountain, "the 5-year" survival rate of a patient with T1 NO MO stage patient is $61 \%$ and a 12 NO MO stage patient $38 \%$. Assuming that the status of the node and the metastases remain unchanged, in $43 \%$ of the patients with undetected early lung cancer the 5 -year survival drops by $23 \%$.

It seems that a miss rate of $19 \%$ can hardly be improved, but missing a lumor has a major impact on the prognosis in most cases. Therefore, we think that patients at risk with a normal chest radiograph should be referred for further evaluation.

A study was performed by Kaneko et al ${ }^{24}$ to investigate if low-dose spiral CT is a better tool to detect early lung cancer with promising results. They suggest using lowdose spiral CT as a screening modality for lung cancer. Considering the potential of spiral CT to lower the miss, rate in the detection of early lung cancer, we think this modality should play a major role in the case finding of patients at risk in the near future.

\section{Acknowledgment}

We thank Gerben ter Riet, MD, for his helpful comments and Annemie Mordant, $\mathrm{BSc}$, for her support in data management.

\section{References}

1. Berlin L. Malpractice and radiologists, update 1986:11.5 year perspective. AJR Am J Roentgenol $1986 ; .47: 1291-1298$.

2. Kenneth AK. Medicolegal analysis of the Delayed Diagnosis of Cancer 338 Cases in the United States. Arch Churg 1994; $129: 397-404$

3. Potchen EJ,Bisesi MA. When is it malpractice to miss lung cancer on chest radiographs? Radiology $1990 ; 175: 29-32$.

4. Woodring JH. Piffalls in the Radiologic Diagnosis of Lung Cancer. A.JR Am J Roentgenol 1990; 154:1165-1175.

5. Brogdon BG, Kelsey CA,Moseley RD. Factors affecting perception of pulmonary lesions. Radiol Clin North Am 1988; 21:633-665.

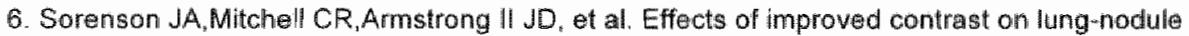
detection: a clinical ROC study. Invest Radial 1987;22:772-780.

7. Kelsey CA, Moseley RD,Brogdon BC, et al Euffect of size and position on chest leston detection. A.JR Am J Roentgenol 1977; 129: 205-208.

8. Austin JHM, Romney BM, Goldsmith LS. Missed bronchogenic carcinoma: lradiographic findingsin 27 patients with a potentally resectable lesion evident in retrospect. Radiology $1992 ; 182: 115 \% 122$

9. Forrest JV.Friedman PJ. Radiologic errors in patients with lung cancer. West J Med 1981; 134 $485-490$

10. Stitik FP. Tockman MS. Radiographic screening in the early detection of lung cancer. Radiol Clin North Am 1978; 16:347-366.

11. Heelan RT' Flehinger BJ,Melamed MR, et al Non small-cell lung cancer. results of the New York screening program. Radiology 1984; $151: 289-293$

12. Mum JR, Miller WE, Fontana RS, et al. Lung cancer detected during a screening program using four-month chest radiographs. Radiology $1983 ; 448: 609-615$.

13. Guiss LW, Kuenstler. A retrospective review of survey photofluorograms off persons with lung cancer. Cancer 1960;13:91-95.

14. Mountain CF. Rewision in the International System for Staging Lung Cancer. Chest 1997; 111: 1710-1717.

15. Hncidence of Cancer in the Central and Southern Part of Limburg. Mastricht, the Netherlands: Maastricht Cancer Registration IKL, 1997.

16. Theros EG. Varying mantestations of peripheral pulmonary neoplasms: A radiologic-pathologic correlative study. A.JR Am J Roentgenol 1977; 128: 893-914. 
17. Melamed MR. Flehinger BJ, Zaman MB, et al. Screening for early lung cancer results of the Memorial Sloan-Kettering Study in New-York. Chest 1984; 86: 44-53.

18. Kundel HL. Predictive value and threshold detectability of lung tumors. Radiology 1981; 139: $25-29$.

19. Swensson RG. Hessel SJ. Herman PG. Omissions in radiology Faulty search or stringent reporting criteria? Radiology 1977: 123:563-567.

20. Kundel HL, Nodine CF, Krupinsiki EA. Searching for lung nodules: visual dwell indications of falsepositive and false-regative decisions. Invest Radiol $1989 ; 24: 472-478$.

21. Kundel HL, Reversz G. Toto L. Contrast gradient and the detection of lung nodules. Invest. Radiol. $1979: 14: 18-22$.

22. Tala E. Carcinoma of the lung: a retrospective study with special reference to pre-diagnosis period and roentgenographic signs. Acta Radiol [Diagn] (Stockh) 1967; 268 (suppl): 1-127.

23. Forrest JV, Sagel SS. The lateral radiograph for early diagnosis of lung cancer. Radiology 1979; 131: $309-310$.

24. Kaneko $M$, Eguchi $k$, Ohmatsu $H$ et al. Peripheral Lung Cancer: Screening and detection with lowdose spiral CT versilis radiography. Radiology 1996; $201: 798-802$. 


\section{Chapter 3}

\section{Detection of lung cancer on the chest radiograph: a study on observer performance ${ }^{*}$}

Quekel LGBA, Kessels AGH, Goei R, van Engelshoven JMA

Presented at the annual meeting of the Radiological Society of the Netherlands, Veldhoven, 1999.

Abstract nominated for the Ernst Schering Award 1999.

Abstract published in: Ned Tijdschr Geneesk 2000; 144: 683. 


\section{Abstract}

Study objectives To study the validity and observers consistency in the detection of lung cancer on the chest radiograph.

Materials and Methods The chest radiographs of 100 clinical cases were interpreted by 14 observers. The radiographs were obtained from 30 patients with initially missed but histopathologically proven non-small cell lung cancer 35 patients with other cardiopulmonary diseases and 35 patients with no abnormalities. The observers consisted of 10 experienced radiologists, 2 experienced chest physicians and 2 residents in radiology. All observers were unaware of the study design. The validity and observer consistency were determined for each observer.

Results The mean sensitivity and specificity of the 10 radiologists were 0.36 and 0.90 . For the 2 chest physicians the mean sensitivity and specificity were 0.29 and 0.96 . For the 2 residents in radiology mean sensitivity and specificity were 0.25 and 0.94 . The mean interobserver kappa and mean intraobserver kappa for the radiologists were 0.38 and 0.54 . For the 2 chest physicians the mean interobserver kappa was 0.43 , while the intraobserver kappa was 0.59 . For the 2 residents in radiology mean interobserver kappa was 0.35 and the intraobserver kappa was 0.42 . There was no significant relation between the consistency parameters and validity parameters. The interobserver and intraobserver kappa values showed good correlation.

Conclusion The validity of the chest radiograph and observers consistency in the detection of nodular lung cancer varies widely. The level of experience is likely to influence the diagnostic performance.

Key words lung neoplasms, thorax radiography, radiology and radiologists, observer performance. 


\section{Introduction}

Disagreements in the interpretation of chest radiographs, often leading to misdiagnosis have been reported frequently $y^{1.8}$ and some authors ${ }^{1,3}$ have found that pathological conditions on the chest radiograph had been missed in up to $20 \%$ of cases. In $50 \%$ of the cases studied there were significant disagreements between observers over the radiological findings and in $41 \%$ there were important errors in the radiological reports. Failure to diagnose malignancies on the chest radiograph has become one of the most common claims in medical malpractice cases. ${ }^{10.12}$ The malignant lesions that have been missed on the chest radiograph are often clearly visible in retrospect. ${ }^{13-16}$ This problem was especially prominent in large screening studies for the early detection of lung cancer. ${ }^{2,17 \times 18}$ In a recent study we have found a $20 \%$ miss rate for lung cancer on the chest radiograph in clinical practice. ${ }^{15}$ If we considered only lesions with a diameter of less than $3 \mathrm{~cm}$ the miss rate increased to $32 \%$.

The clinical use of any method for diagnostic imaging depends on its vallidity in the detection of pathological conditions in various stages of disease. This diagnostic validity is influenced by the inter-and intraobserver variations in the interpretation of the images obtained. Several investigations have been performed in order to assess the variability in radiologists' interpretation of the chest radiograph ${ }^{2-5}$ Inter-and intraobserver variations have been assessed for the chest radiograph in screening studies for pulmonary tuberculosis and an interobserver agreement of $70 \%$ with an intraobserver agreement of $78 \%$ was found ${ }^{6}$ Assuming a minimal chance expected agreement rate of $50 \%$, these values would correspond with kappas of 0.40 and 0.56 respectively.

This moderate observer agreement suggests that differences in the level of experience or the quality of the radiologists might be a possible explanation for the high miss rate, especially with small lesions.

The purpose of this study was to investigate the variability in observer performance in the detection of early lung cancer on the chest radiograph by determining the validity and observer variability for a number of observers. To examine whether it was possible to improve the performance, the influence of the level of experience on performance was determined. In addition, the relation between observer variability and validity was studied.

\section{Materials and methods}

The study material consisted of 100 clinical cases with original posterior-anterior and lateral chest radiographs of good quality as determined by consensus between three radiologists who co-authored the study. The chest radiographs were obtained in the 125- to $150-\mathrm{kVp}$ range, grid ratio $12: 1$, focus film distance $150 \mathrm{~cm}$, rare earth screen with speed class 400 (Agfa ortho regular or Agfa curix HT-U films; Agfa Gevaert; Mortsel, Belgium). Thirty-five of the chest radiographs showed no abnormalities as determined between 2 radiologists by consensus. In order to conceal the objective of this study from the observers, 35 radiographs with cardiopulmonary disease other than malignancy were added. These pathological conditions included heart failure, COPD, interstitial and parenchymal lung disease according to the consensus of the referring clinician and two radiologists. Thirty radiographs displayed nodular lesions, which were histopathologically proven non small-cell lung carcinoma. They were selected from a set of 51 lesions which were previously missed in clinical practice 
and are described in an earlier publication. "For all selected cases the posterioranterior and lateral chest radiographs should be avalable and of good quallty. Furthermore, the lesion should be unequivocally and definitely visible as determined by consensus between three radiologists. The diameter of the selected lesions waried from $5 \mathrm{~mm}$ to $40 \mathrm{~mm}, 23(72 \%)$ had no or partly sharp borders and $21(70 \%)$ had superposing structures. The selection of initially missed lesions was done in order to make potential differences in observer performance become more apparent. By increasing the proportion of malignant lesions to $30 \%$, which is much higher than in daily practice, the precision of estimations of the validity and consistency parameters was improved.

All chest radiographs were presented to 14 observers in a random order. The 14 observers consisted of 10 radiologists who had been practicing between 5 and 20 years, 5 radiologists were related to a large teaching hospital and the other 5 radiologists worked at a university hospital. The two chest physicians had more than 10 years of experience in clinical practice, and the two residents in radiology were in their fourth year of training. All observers were unaware of the purpose and design of the study. Because the clinical history and the previous chest radiograph probably be an extra source of disagreement, this information was not made available to the observers. No viewing time limit was imposed and the observers were free to take a break whenever they wished. All observers were asked to fill in a prearranged checklist on which they had to indicate whether the plain film was normal or abnormal. If there was an abnormality, the observers were asked to classify the pathological condition into 11 different groups according to the classification index for radiological diagnosis of the American College of Radiology, namely, alveolar consolidation/disease, reticular and/or nodular interstitial abnormalities/disease, atelectasis, hyperinflation/emphysema, lesions and abnormalities of bronchi, vessels, pleura, mediastinum, heart and bone. All abnormalities had to be localized into specific lung lobes and regions such as hilar, parahilar or peripheral. To give the observer the opportunity to express his or her uncertainty, all items were scored on a three point scale: not present, probably present and definitely present.

Four months after the first reading session a second session was held in which the following observers were selected at random: 5 radiologists, 1 chest physician and 1 resident in radiology. The remaining 7 observers were involved in another study with different objectives. The second reading session was held in the same way, using the same set of radiographs. The results of the presence of nodular lesions in the lung lobes or regions of one side were combined to one result by taking the highest degree of certainty for each lung. Thus the analysis was done with 200 lungs. The observer variability was determined by calculating a weighted kappa with linear disagreements weights and its $95 \%$-confidence interval for the three point scale on which the presence of a nodular lesion had to be assessed (not present, probably present and definitely present). Interobserver kappa"s were calculated with the results of the first session.

To construct an interobserver kappa for each of the observers, the results of the ten radiologists were used as a reference. A mean interobserver kappa for the 2 chest physicians and the 2 radiology residents was calculated by averaging the kappa's of each of them with the ten radiologists. A mean interobserver kappa for each radiologist was calculated by averaging the kappa's of the radiologist concerned and the nine others. The standard deviation of this mean kappa was calculated from the mean of the variances of the kappa statistic. In order to compare the results obtained with those in the literature ${ }^{5}$ an overall observer agreement rate for the ten 
radiologists was calculated. To interpret this agreement rate the mean positive result rate, i.e. the propontion of the positive results, was determined.

The validity was determined by calculating the sensitivity, the specificity and the (diagnostic) Odds Ratio with its $95 \%$-confidence interval for each observer in the first reading session. For this aim the result of the assessment of nodular lesions was dichotomized by combining the categories "probably present" and "definitely present" into the category "positive test result".

\section{Results}

In Table 1 the mean inter- and intraobserver kappa's, the sensitivity, the specificity and the diagnostic Odds Ratio are shown for all observers.

Table 1. Diagnostic characteristics of the observers; inter-and intraobserver kappa-values with the standard deviation, the sensitivity, the specificity and the Odds Ratio and its $95 \%$ Confidence Interval.

$\begin{array}{lll}\text { Interobserver Intraobserwer Sensitiwity Specificity } & \text { Odds Ratio } \\ \text { Kappa (sd) } & \text { Kappa (sd) } & (95 \% \text { c.i.) }\end{array}$

\begin{tabular}{|c|c|c|c|c|c|}
\hline Radiologist 1 & $0.34(0.09)$ & $0.48(0.08)$ & 0.30 & 0.88 & $3.04(1.22$ to 7.49$)$ \\
\hline Radiologist 2 & $0.31(0.10)$ & - & 0.20 & 0.92 & $3.02(1.05$ to 8.76$)$ \\
\hline Radiologist 3 & $0.44(0.09)$ & - & 0.43 & 0.87 & $5.14(2.201012 .1)$ \\
\hline Radiologist 4 & $0.37(0.09)$ & $0.56(0.09)$ & 0.33 & 0.92 & $5.57(2.19$ to 14.2$)$ \\
\hline Raidiologist 5 & $0.42(0.09)$ & - & 0.37 & 0.92 & $6.45(2.58$ to 16.3$)$ \\
\hline Rardiologist 6 & $0.40(0.08)$ & $0.66(0.07)$ & 0.60 & 0.89 & $12.7(5.26$ to 30.4$)$ \\
\hline Riadiologist 7 & $0.46(0.09)$ & $0.59(0.10)$ & 0.20 & 0.92 & $3.02(1.22$ to 7.49$)$ \\
\hline Radiologist 8 & $0.31(0.09)$ & - & 0.30 & 0.88 & $304(1.22$ to 7.49$)$ \\
\hline Radiologist 9 & $0.37(0.09)$ & $0.39(0.08)$ & 0.50 & 0.91 & $9.63(3.99$ to 23.3$)$ \\
\hline Radiologist 10 & $0.38(0.09)$ & - & 0.37 & 0.92 & $699(2.77$ to 17.9$)$ \\
\hline Mean Radiologists & $0.38(0.09)$ & $0.54(0.09)$ & 0.36 & 0.90 & $5.35(3.69$ to 7.75$)$ \\
\hline Chrest physician 1 & $0.44(0.10)$ & - & 0.20 & 0.97 & $8.25(2.371029 .6)$ \\
\hline Chest physician 2 & $0.42(0.10)$ & $0.59(0.10)$ & 0.37 & 0.95 & $10.4(3.811028 .2)$ \\
\hline Resident-radiol 1 & $0.32(0.10)$ & $0.42(0.13)$ & 0.20 & 0.95 & $4.47(1.46$ lo 13.7$)$ \\
\hline Resident-radiol 2 & $0.38(0.09)$ & - & 0.30 & 0.92 & $5.18(1.9910 \quad 1.37)$ \\
\hline
\end{tabular}

For the radiologists, overall means were calculated for all the diagnostic parameters. The mean inter-and intraobserver agreement rates were $85 \%$ and $90 \%$, respectively. The positive result rate was $13.6 \%$, corresponding with a chance expected agreement rate of $76.5 \%$. Observer performance is primarily determined by the validity parameters. In particular the sensitivity and the diagnostic Odds Ratio showed a large variability between all observers. This could have been caused by different cut-offs in the criteria the observers used for categorizing the radiological findings. In figure 1 the sensitivity has been plotted against one minus the specificity to examine whether these points followed an ROC-curve. It was clearly not possible

* Unlike the sensitivity and specificity the Odds Ratio describes the diagnostic capacity of a test with only one parameter; if the Odds Ratio equals one, there is no relation between test result and disease, thus the Odds Ratio of a discriminating test should significantly differ from one. 
Whe single curve though the points indicating differences in the ability of the okstrors to detect nodular lesions.

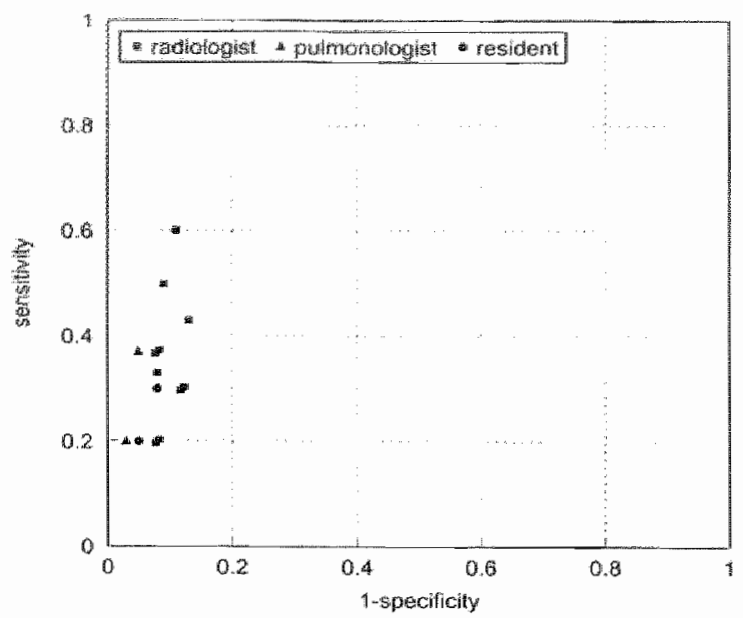

Figure 1. Scatterplot of the sensitivity against one minus the specificity for 10 radiologists, 2 chest physicians and 2 residents.

The inter- and intraobserver kappa values also showed a high variability. The relation between the diagnostic Odds Ratio and observer variability is displayed in Figure 2.

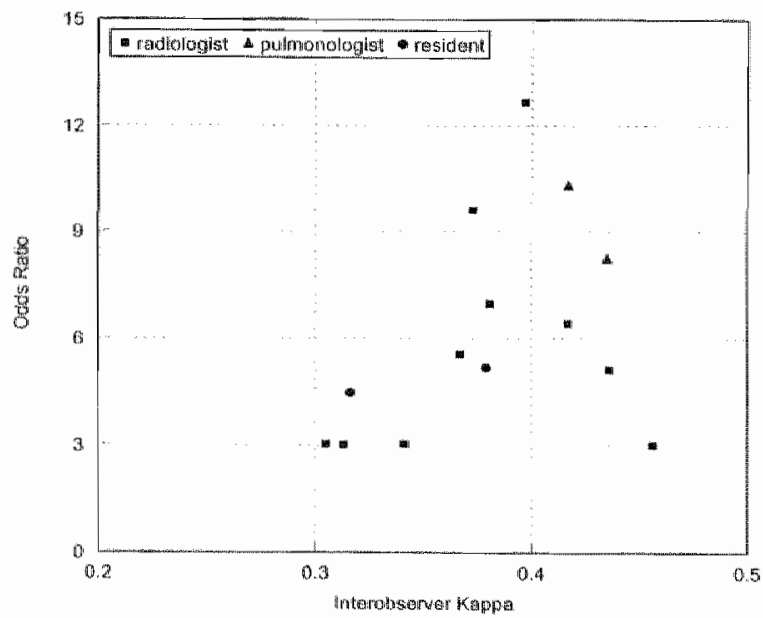

Figure 2. Scatterplot of the odds ratio against the interobserver kappa for 10 radiologists, 2 chest physicians and 2 residents.

This plot and the calculated Spearman rank correlation coefficient of the inter-and intraobserver kappa with the Odds ratio of respectively 0.34 (one tailed $p=0.12$ ) and 0.21 (one tailed $p=0.32$ ) indicated that there was no significant relation between the 
consistency parameters and the validity parameters. The intraobserver kappa is plotted against the interobserver kappa in Figure 3.

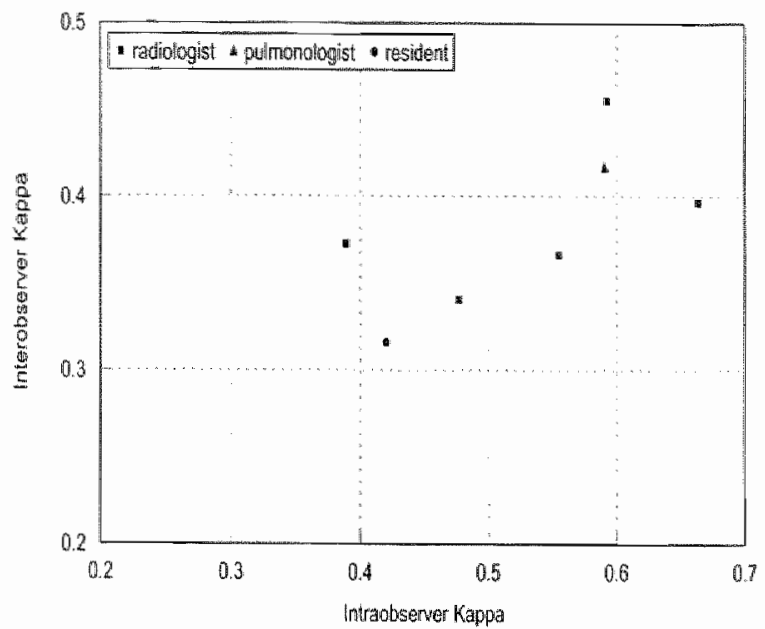

Figure 3. Scatterplot of the interobserver kappa against the intraobserver kappa for 5 radiologists, a chest physician and a resident.

This figure and a Spearman rank correlation coefficient of 0.68 (one-tailed $p=0.047$ ) showed that intra- and interobserver kappa values were clearly correlated.

\section{Discussion}

The results of this study show large differences in diagnostic performance between the ten radiologists, two chest physicians and two residents in radiology in detecting lung cancer presenting as nodular lesions on the chest radiograph. These differences emerged both in the validity and in the consistency parameters. These results should not be extrapolated to daily clinical practice as the clinical history and the previous chest radiographs were not made available. Furthermore, the higher prevalence (30\%) of lung cancer in the study material was artificial. In addition, the radiographs showing nodular lesions originated from a set of chest radiographs from patients with lung cancers which had initially been missed. This may also explain the low to moderate values for the validity parameters of the radiologists. Another explanation of these low values might be the low positive result rate of $13.6 \%$. As this rate is much lower than the $30 \%$ nodular lesion rate in the set of radiographs, it indicates that the radiologists intuitively scored according to the clinical prevalence of nodular lesions.

Because of the selection of initially missed lung cancers, these results are not really comparable with those found in the literature. Furthermore, only the values for the miss rates are reported in the literature from which the sensitivity can be derived (sensitivity equals one minus the miss rate) but not the specificity. In several screening studies the proportion of missed lung cancers on chest radiographs varied between $25 \%$ and $90 \% .^{17-18,21}$ In a small study carried out by Forrest and Friedman ${ }^{13}$ 
the lesion was missed in 8 of $20(40 \%)$ patients with lung cancer. The generally accepted miss rate for the radiological detection of early lung cancer lies between $20 \%$ and $50 \%, 2$ corresponding to values for sensitivity of $80 \%$ and $50 \%$.

Several studies have been performed on abserver variability in the interpretation of the chest radiograph. ${ }^{1.7 .23}$ However, to our knowledge, no studies have addressed the observer variability in the detection of lung cancer. In his study on pulmonary tuberculosis presenting as small pulmonary lesions, Yerushalmy found an interobserver agreement rate of $70 \%$ and an intraobserver agreement rate of $79 \%$. In the present study agreement rates of $85 \%$ and $90 \%$, respectively were found. Other studies have evaluated the inter-and intraobserver variability on the presence of an infiltrate on the chest radiograph, and have shown interobserver agreement rates between $59 \%$ and $87 \%$ with kappa values of 0.37 to $0.72 .^{3-4.8}$ Melbye and Dale $^{8}$ compared the radiological diagnosis of pneumonia in adult outpatients by the consensus of a panel (as reference), with that made by radiologists, residents and a specialist in chest medicine. They found kappa values of 0.71 .0 .50 and 0.72 , respectively, and concluded that experience was an important factor. Young and Marrie $^{3}$ studied agreement rates on the presence or absence of pneumonia as judged by the reporting radiologist, medical students, residents and staff physicians with three board-certified radiologists as reference. They found values of $87 \%, 67 \%$, $87 \%$ and $80 \%$, respectively and concluded that experience did have a moderate influence on observer agreement. However, Herman and Hessel ${ }^{24}$ found no correlation between the level of experience and agreement in the interpretation of chest radiograph. Two studies have assessed the interobserver agreement on the presence of disease on the chest radiograph. One of them" found disagreement in $41 \%$ and indeterminate disagreement in $56 \%$ of the reports. The other study ${ }^{5}$ determined kappa values for the abnormal and the normal radiographs separately and found values of 0.40 and 0.24 , respectively. Our results on observer variability are in the same range as mentioned in the literature, notwithstanding the differences in study design.

The range of the sensitivities in this study (20\% to $60 \%)$ and those of the diagnostic Odds Ratios (3.0 to 12.7) reflects significant differences between the ten radiologists in the diagnostic vallidity of their reports. Several explanations can be found for these differences. Missing a lesion can be caused by simply not seeing it. A lesion may be interpreted as part of an adjacent anatomical structure or as a composition of two superimposed structures such as a rib and a vessel. Conversely, a part of an anatomical structure or a composed shadow of two superimposed structures can lead to a false positive interpretation. This indicates that the diagnostic process is very complex, depending on the characteristics of the image itself as well as on the perceptual and judgmental abilities of the observer.

In the present study, the radiologist with the best validity parameters (no. 6) has specialized in chest radiology. The odds ratios and the plot show that the chest physicians also report with a relatively high diagnostic validity, characterized by the combination of a high specificity and a moderate sensitivity. This could imply that chest radiologists perform better in detecting nodular lesions. Three of the participating radiologists are involved in a mammography screening program (nos. 8 , 9 and 10) and have extensive experience in the detecting of early staged, subtle lesions. Two of them showed better than average performance.

Inter-and intraobserver kappa's also vary substantially. As expected, the inter- and intraobserver variability results are highly correlated $(r=0.6 .8)$ but we found no strong relation between the odds ratio and interobserver variability. This means that for the 
detection of small nodular lesions on the chest radiograph, a high value for the interobserver kappa does not predict high values for the validity parameters as is notably shown by two radiologists (nos. 7 and 3 ) in Figure 2. However, the figure suggests that observers with a low interobserver kappa will probably perform poorly in detecting nodular lesions. Double reading could improve these results, i.e. it will increase the sensitivity but it consequently decreases the specificity and is very time consuming and expensive. ${ }^{25-27}$

This study shows that the validity of the plain chest radiograph in detecting small lesions varies widely among different radiologists. As the results suggests that the level of experience influences the diagnostic performance, subspecialization or specific training is recommended in order to improve the diagnostic validity in the detection of these lesions. A recommendation with more consequences for clinical practice would be a periodical quality check on the performance as is customary in the Dutch mammography screening program.

\section{References}

1. Herman PG, Gerson DE, Hessel SJ, et al. Disagreements in chest roentgen interpretation. Chest $1975 ; 68: 278-282$.

2. Amandus HE, Pendergrass EP, Dennis JM, Morgan WK. Pneumoconiosis: interreader variability in the classification of the type of small opacities in the chest roentgenogram. A.JR 1974; 122: 7407.43 .

3. Young $M$, Marrie $T J$. Interobserver variability in the interpretation of chesti roentgenograms of patients with possible pneumonia. Arch Intern Med 1994; 154:2729-2732.

4. Albaum MN, Hill $\mathrm{LC}_{\text {. }}$ Murphy $\mathrm{M}_{n}$ et al. Interobserver reliability of the chest radiograph in communityacquired pneumonia. PORT Investigators. Chest 1996; 110:343-350.

5. Tudor GR, Finlay D. Taub N. An assessment of inter-observer agreement and accuracy when reporting plain radiographs. Clin Radiol 1997; $52: 235-238$.

6. Yerushalmy J. The statistical assessment of the variability in observer perception and description of the roentgenographic pulmonary shadows. Radiol Clin North Am 1969; $7: 381-392$.

7. Cochrane $\mathrm{AL}$, Garland LH. Observer error in the interpretation of chest films: an international investigation. Lancet $1952 ; 2: 505-509$.

8. Melbye $H$, Dale K. Interobserver variability in the radiographic diagnosis of adult outpatient pneumonia. Acta Radiol 1992; 33:79-81.

9. Garland LH. Studies on the accuracy of diagnostic procedures. AJR 1959; 82: 25-38.

10. Berlin L. Malpractice and radiologists, update 1986: Ain 11.5-year perspective. AJR 1986; 147: $1291-1298$.

11. Spring $D B$, Tenmenhouse DJ. Radiology malpractice lawsuits: Califormia jury verdicts. Radiology $1986 ; 159: 811-814$

12. Hammer MM, Morlock F, Foley HT, Ros PR. Medical malpractice in diagnostic radiology: claims, compensation, and patient injury. Radiology $1987 ; 164: 263-266$.

13. Forrest JV, Friedman PJ. Radiologic errors in patients with lung cancer. West J Med 1981; 134 : 485-490.

14. Austin $\mathrm{JH}$, Romney BM, Goldmith LS. Missed bronchogenic cancinoma: radiographic findings in 27 patients with a potentially resectable lesion evident in retrospect. Radiology 1992; 182:115-122.

15. Quekel LGB, Kessels AGH, Goei R, wan Engelshoven JMA. Miss rate of lung cancer on the chest radiograph in clinical practice. Chest $1999 ; 115: 720-724$.

16. Mountain CF. Revisions in the International System for Staging Lung Cancer. Chest $1997: 111$ $1710-1717$

17. Stitik FP. Tockman MS. Radiographic screening in the early detection of lung cancer. Radiol Clin North Am 1978: 16: $347-366$.

18. Heelan RT, Flehinger BJ, Melamed MR, et all. Non-small-cell lung cancer: results of the New York screening program. Radiology $1984 ; 151: 289-293$.

19. Cohen J. Weighted Kappa: Nominal scale agreement with provision for scaled disagreement or partial credit. Psychiological Bulletin 1968; 70: 213-220.

20. Muhm JR, Miller WE, Fontana RS, Sanderson DR, Uhlenhopp MA. Lung cancer detected during a screening program using four-month chest radiographs. Radiology $1983 ; 148: 609-615$. 
21. Guiss $L W_{i}$ Kuenstler. A retrospective review of survey photofuorograms of persons with lung cancer. Camcer $1960 ; 13: 91-95$.

22. Coblentz CL, Babcook CJ. Alton D. Riley Bu, Norman G. Observer variation in detecting the radiologic features associated with bronchiolitis. Invest Radiol 1991: 26 : 115-118.

23. Herman $P Q_{1}$. Hessel SJ. Accuracy and its relationship to experience in the interpretation of chest radiographs. Irvest Radiol $1975 ; 10 ; 62-67$.

24. Hessell SJ, Herman PG, Swenson RG. Improving performance by multiple interprettations of chest radiographs: effectiveness and cost. Radiology $1978 ; 127: 589-598$.

25. Thurfjell EL, Lemevall KA, Taube AA. Benefit of independent double reading in a population-based mamimography screening program. Radiology 1994; 191: 241-244.

26. Warren RML, Duffy SW. Comparison of single reading with double reading of mammograms and change in effectiveness with experience. $\mathrm{Br} /$ Radiol 1995; 68: 958-962. 
Chapter 4

\section{Detection of lung cancer on the chest radiograph: impact of previous films, clinical information, double reading and dual reading*}

Quekel LGBA, Goei R, Kessels AGH, van Engelshoven JMA 


\section{Abstract}

Purpose To study the impact of clinical information, previous chest radiographs, double reading (one pair of observers read the films independently) and dual reading (one pair of observers read the films simultaneously) on the sensitivity, specificity and odds ratios of observers in the detection of early lung cancer on the chest radiograph.

Materials and methods The study was performed in 3 sessions. In the first session, 14 observers reviewed the chest radiographs of 100 cases ( 30 with early lung cancer, 35 with no abnormalities, 35 with other cardiopulmonary diseases).

Sensitivity, specificity, odds ratios and the effect of double reading were calculated. After 4 months, a second session was held in which 7 abservers reviewed all cases with the provision of all information. The other 7 observers reviewed all cases without information again. To determine the effect of dual reading, in the third session, 4 pairs of observers reviewed all cases in which they disagreed in the first independent reading session. The effects of information, double reading and dual reading on sensitivity, specificily and odds ratio were calculated.

Results The sensitivity of the observers in the first session ranged from 0.20 to 0.60 and the specificity from 0.87 to 0.95 . In the second session, these parameters changed only slightly, independent from the availability of clinical information and previous films. With double reading the sensitivity increased and specificity decreased. With dual reading sensitivity increased and specificity remained unchanged. The odds ratios were improved with double reading by $4 \%$ and with the dual reading by $14 \%$.

Conclusion Additional clinical information, previous chest radiographs, double reading and dual reading have little impact on the detection of early lung cancer on the chest radiograph.

Key words radiography thoracic, lung-neoplasms-diagnosis, observer-variation, sensitivity and specificity, odds ratio. 


\section{Introduction}

Early stage lung cancer presenting as a small lesion on the chest radiograph, but overlooked by the reporting radiologist, is a well known phenomenon. ${ }^{13}$ In the literature the proportion of missed lung cancers on the chest radiograph varies between $25 \%$ and $90 \%$, with a generally accepted error rate between $19 \%$ and $50 \%$. $^{4-7}$

There are many reasons given for missing lung cancer on the chest radiograph, including poor lesion conspicuity, poor viewing conditions, lechnically poor images, errors in perception and misinterpretation by the viewer ${ }^{1-2.8-10}$ Availability of the clinical information and of a previous chest radiograph is presumed to lower the diagnostic error. In daily clinical practice this additional information is usually thought to have a positive effect on the detection of subtle lesions on the chest radiograph. However, although some studies have indeed reported that the availability of the clinical information increased the diagnostic accuracy, ${ }^{11-15}$ other studies found no significant increase in accuracy and even suggested that it could even lead to distraction. ${ }^{1617}$ The expectation that previous radiographs ahways increases accuracy was not confirmed by Callaway et al. ${ }^{18}$ who performed a study on the influence of previous films on the interpretation and detection of breast cancer. To our knowledge, the effect of providing both the clinical information and the previous chest radiograph in order to improve the accuracy of the chest radiograph in the detection of lung cancer has not been studied previously,

As shown in mammography screening studies ${ }^{19-22}$ and in a study on multiple interpretations in chest radiography ${ }^{23}$ the "double reading" technique can improve the detection of early stage cancer. With this method the results of two separate observers are combined to yield one result: it is considered negative if both results are negative and positive if at least one of the individual results as positive. This algorithm is described as the "OR" rule in the literature. ${ }^{20.22 .24}$ The two observers can also reach a consensus by simultaneously reviewing those radiographs over which they disagree. In the following we will call this procedure "dual reading".

The purpose of the present study was twofold: firstly to determine the effect of the availability of allerting clinical information and the previous chest $X$-rays on the accuracy of detection of lung cancer on the chest $X$-ray and secondlly, to assess the effect of double reading and dual reading on the accuracy of detection.

\section{Materials and methods}

\section{Radiographs}

A total of one hundred cases for this study were selected among patients in whom good quality posterior-anterior and lateral chest radiographs were taken at Atrium Medical Center in the period from 1992 to 1997 . Thirty-five radiographs showed no abnormalities, as determined by consensus of three co-authors. In order to conceal the objectives of the study from the observers, radiographs of 35 patients with cardiopulmonary disease other than malignancy were added. These pathological conditions included heart failure, COPD and interstitial or parenchymal lung disease according to the consensus of two radiologists and the attending clinician. Thirty patients had histopathologically proven non small-cell lung cancer presenting as a small lesion on the chest $X$-ray. These nodular lesion had to be unequivocally and definitely visible as determined by consensus between three radiologists who coauthored this study. The radiographs were selected from a set of 51 patients with 
lesions which had previously been missed in clinical practice and have been described in an earlier publication. ${ }^{7}$

For all 100 selected cases the posterior-anterior and lateral chest radiographs had to be present and of good quality, as determined by consensus between the authors. In addition, radiographs two to five years prior to the index films had to be present and of good quality. All chest radiographs were obtained in the 125 - to $150-\mathrm{kV}$ range, grid ratio $12: 1$, focus-fim distance $150 \mathrm{~cm}$, rare earth screen with speed class 400 (Agfa ortho regular or Agfa curix HT-U films; Agfa Gevaert; Mortsel, Belgium) and were free of markers. The diameter of the selected lesions varied from $5 \mathrm{~mm}$ to 40 $\mathrm{mm}, 23(72 \%)$ had no or partly sharp borders and $21(70 \%)$ had superposing structures. The selection of initially missed lesions was done in order to make potential differences in observer performance become more apparent. We choose to include subtle lesions in our study material in order to make possible changes in accuracy by additional clinical information, double or dual reading become more apparent.

\section{Procedure}

The reading was done in three sessions:

Session 1. In the first reading session the 100 chest radiographs were presented to the observers in a random order without prior films or any information on the referring clinicians' level of suspicion of malignancy. The group of 14 observers consisted of 10 experienced radiologists with more than 10 years of experience in clinical

practice, two experienced chest physicians with the same amount of experience and two residents in radiology in their fourth year of training. By pairwise matching 5 pairs of radiologists, one pair of pulmonologists and one pair of residents in radiology were formed. The radiollogists were matched on experience and expertise as follows: more or less than 20 years of experience, whether or not involved in a breast screening program and general radiologists versus subspecilalists in neuroradiology. These pairs were used for the dual and double reading in session 3.

All obserwers were unaware of the purpose of the study and they had not seen the films previously. No time limit was given for viewing the 100 radiographs. The observers were asked to fill in a prearranged short checklist on which they had to indicate whether the plain film was normal or pathological. Any pathological condition had to be classified into 11 different categories according to the classification index for pathological diagnosis by the American College of Radiology:" alveolar consolidation/disease, reticular and/or nodular interstitial abnormalities/disease, atelectasis, hyperinflation/emphysema, lesions and abnormalties of bronchi, vessels, pleura, mediastinum, heart and bone. The disease had to be localized in specific lung lobes or in the hilar "parahilar or peripheral regions and had to be categorized on a three pount scale: not present, probably present or definitely present. For statisticall analysis the result was dichotomized by combining the categories "probably present" and "present" into the category "positive test result".

Session 2. After four months, a second reading session with the same 100 chest radiographs was held. Within each pair, as formed in session 1, one observer was randomly selected for the group which received no additional information. The remaining observer was provided for all patients with the previous posterior-anterior and lateral chest radiograph and additional standardized clinical information, namely "syspicion of malignancy". In this second session the same cases were used in a different random order. Each observer filled in the same prearranged checklist that 
had been used in the first study session, but was not aware of reading the same films. Session 3 . The possible benefit of double reading and dual reading was investigated as follows. For the double reading the all pairs of observers from session 1 were used. Twelve months after the first session, dual reading was performed by four of these pairs of observers who reviewed simultaneously those radiographs over which the two observers had disagreed in the first independent reading session.

The results of single reading, double reading and duall reading were analyzed by calculating specificities, sensitivities and Odds Ratios ${ }^{2}$. For all inferential analyses the logarithm of the Odds Ratio was used. To analyze the effect on the accuracy of additional clinical information and previous radiograph compared with no information at all, the differences of the logarithm of the Odds Ratio of the first and second session for each observer was calculated. These differences within each pair of observers were analyzed using a paired t-test. The benefit of double reading and dual reading compared with the result of single reading in the first session was also tested with a paired t-test.

\section{Results}

The sensitivity and specificity in the detection of lung cancer for the first and second sessions, the double reading and dual reading procedures are presented in Table 1. The sensitivity in the first session varied from 0.20 to 0.60 and specificity varied from 0.87 to 0.95 . These parameters changed only slightly at the second session.

Table 1. Sensitivity and specificity in detecting lung cancer for the first and second sessions, as well as the double reading and dual reading procedures.

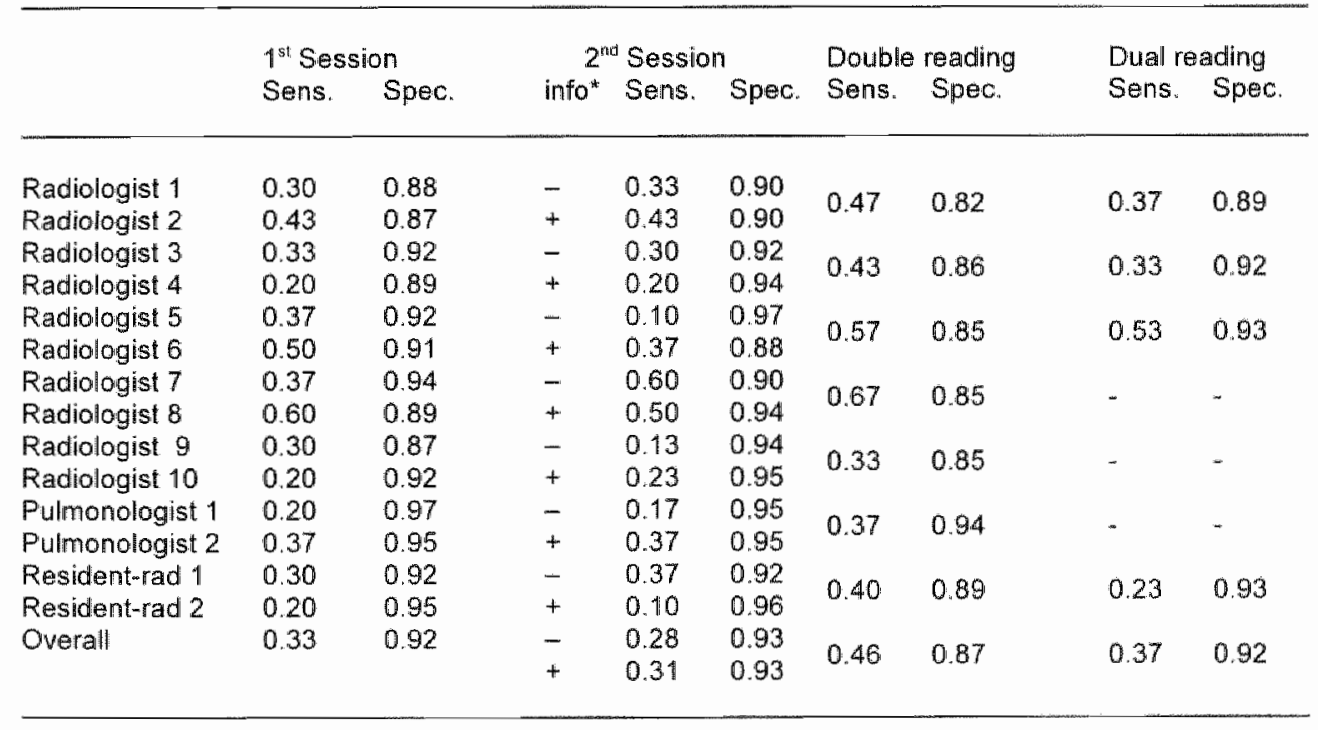

*: additional clinical information and previous radiograph provided $(+)$ or nol $(-)$.

\footnotetext{
anlike the sensitivity and specificity (or Likelihood Ratios), the Odds Ratio describes the diagnostic performance of a test with one parameter and in this way a more straightforward comparison of different test modalities is possible; if the Odds Ratio equals one there is no relation between test result and disease "thus the Odds Ratio of a discriminating test should significantly differ from one
} 
The 7 observers without clinical information and previous radiographs scored a mean sensitivity of 0.31 and a mean specificity of 0.92 . This changed respectively to 0.28 and to 0.93 . For the observers with information these parameters changed respectively from 0.36 to 0.31 and 0.92 to 0.93 . With double or dual reading the sensitivity increased and the specificity decreased. In Table 2 the diagnostic Odds Ratio of the second session (with and without clinical information) and the Odds Ratio after double and dual reading are compared with the Odds Ratio of the first session by presenting the percentual change.

Table 2. Diagmostic OR of the first session and the change in \% of the OR in the second session, and the double reading and dual reading procedures.

\begin{tabular}{|c|c|c|c|c|c|}
\hline & $\begin{array}{l}1 \text { Session } \\
\text { Dhagn. OR }\end{array}$ & info" & $\begin{array}{l}2^{\text {sid }} \text { Session } \\
\text { OR. \% change }\end{array}$ & $\begin{array}{l}\text { OR } \\
\% \text { changes reading } \\
\% \text { change }\end{array}$ & $\begin{array}{l}\text { OR duat ratands } \\
\text { \% change }\end{array}$ \\
\hline Radiologist 1 & 3.04 & - & $+48 \%$ & $+29 \%$ & $+\quad 51 \%$ \\
\hline Radiologist 2 & 5.14 & + & $+34 \%$ & $-24 \%$ & $-\quad 21 \%$ \\
\hline Radiologist 3 & 5.57 & - & $7 \%$ & $-16 \%$ & $0 \%$ \\
\hline Radiologist 4 & 3.02 & + & $4 \%$ & $+54 \%$ & $+\quad 80 \%$ \\
\hline Radiologist 5 & 6.99 & - & $-\quad 57 \%$ & $+\quad 8 \%$ & $+115 \%$ \\
\hline Radiologist 6 & 0.63 & + & $-55 \%$ & $-21 \%$ & $+\quad 56 \%$ \\
\hline Radiologist 7 & 6.45 & - & $+109 \%$ & $+80 \%$ & - \\
\hline Radiologist 8 & 12.67 & + & $+14 \%$ & $8 \%$ & - \\
\hline Radiologist 9 & 3.04 & - & $-\quad 27 \%$ & $9 \%$ & - \\
\hline Radiologist 10 & 3.02 & + & $+80 \%$ & $8 \%$ & $=$ \\
\hline Pulmonalogist 1 & 8.25 & - & $-51 \%$ & $9 \%$ & - \\
\hline Pulmonologist 2 & 10.36 & + & $+13 \%$ & $-19 \%$ & - \\
\hline Resident-rad 1 & 5.18 & - & $+35 \%$ & $+9 \%$ & $-\quad 23 \%$ \\
\hline Resident-rad 2 & 4.47 & + & $-42 \%$ & $+\quad 26 \%$ & $-\quad 10 \%$ \\
\hline
\end{tabular}

*: additional clinical information and previous radiograph provided $(+)$ or not $(-)$.

On average, the ORs of the observers with information decreased by $3 \%$ and the observers with no additional information decreased by $8 \%$. On balance, the group with information performed $4 \%$ better (two tailed $p=0.25$ ) than the group without information. The diagnostic accuracy of the first session improved with the double reading procedure by $4 \%$ (two tailed $p=0.6$ ). When calculated for these eight observers who also performed the dual reading procedure, this improvement was $8 \%$ (two tailed $p=0.4$ ). The dual reading procedure increased the mean Odds Ratio by $14 \%$ (two tailed $p=0.3$ ). The disagreement within these four pairs in the first reading session ranged from $23 \%$ to $31 \%$.

\section{Discussion}

This study shows that improvement in detecting lung cancer presenting as a small lesion on the chest $X$-ray by the provision of the clinical information and the previous chest $X$-rays is small $(+4 \%$ ) and statistically not significant. The same is true for double reading $(+4 \%)$ and to a lesser degree for dual reading $(+14 \%)$. The values of the sensitivities and specificities should not be extrapolated to daily clinical practice because the radiographs showing nodular lesions originated from a set of radiographs from pattients with initially missed lung cancers. This was done to create 
optimal conditions to study" whether or not clinical information, previous chest radiographs, double and dual reading were able to improve the accuracy of diagnosis.

The impact of clinical information and previous radiographs on observer performance is important in deciding whether this information should be presented to the radiologist. In several studies in which the clinical intormation was made available to the observers, a statistically significant increase in the overall performance of the readers of chest radiographs was found: the rate of true positives increased from $38 \% 10.84 \% .^{12-13,26}$ In a study of Tudor et al. ${ }^{14}$ no statistically significant increase in accuracy was found, i.e. the sensitivity increased from $80 \%$ to $83 \%$ and the specificity from $72 \%$ to $76 \%$. In other studies ${ }^{11.11 .22}$ the results were not consistent; no statistically significant increase in the detection of small pulmonary nodules was found after providing clinical information, while other subtle pathology such as pneumonia, tuberculosis, metastatic disease, mediastinal disease, congenital abnormalities and traumata were detected more accurately. This was explained by the fact that in nodule detection only directed attention was needed whereas with other abnormalities both attention and pattern recognition was required.

Callaway et al. ${ }^{18}$ performed a study concerning the impact of previous films on the detection of breast cancer. On average there was no difference in diagnostic accuracy before and after providing previous films although the majority of the observers showed an increase in diagnostic accuracy. However, with some observers the presence of the previous films had a negative effect on performance as a result of downgrading previously diagnosed malignant changes.

In the present study, we compared two groups of observers: one group which received standardized climical information and the previous chest radiographs and one group without this additional information. The Odds Ratio, the sensitivity and specificity did not change (Tables 1 and 2). Intuitively, we expected a substantial improvement in the accuracy by providing the clinical information and the previous chest radiograph. There may be two reasons why the validity parameters did not increase and even slightly decreased in both groups. First, detecting nodules on the plain chest radiograph is generally a routine procedure in which additional information has little or no impact. Second, with the reviewing of 100 radiographs in the second session a possible decrease of motivation could influence the concentration of the observer. Double reading is a well known method for increasing the sensitivity in detecting abnormalities radiologically, and has been extensively used in screening mammography. Beam et al. ${ }^{24}$ found in their mammography study dealing with the effect of double reading that, on average, radiologists increased the true positive rate by $8-14 \%$ but concomitantly increased the false positive rate by 4 $10 \%$. In several studies ${ }^{20-22}$ in which comparisons were made between single- and double reading in mammography, a $12-15 \%$ increase in cancer detection was found. The sensitivity was increased significantly while the specificity was almost unchanged. Hessel et al. ${ }^{23}$ studied several methods of double reading with chest radiographs and concluded that resolving disagreement in favor of the positive diagnosis by double reading in which the second observer had knowledge of the result of the first observer, appeared to be the best method for reducing the false negative rate, even though it almost doubled the number of false-positive diagnoses. The underlying hypothesis was, that the result of the first observer would lead to carelessness or prejudice by the second observer, and consequently would have a negative influence on accuracy. The question arises whether this also holds true for dual reading. In dual reading the discussion between the two radiologists usually 
involves a process of adjudication when there is initial disagreement in interpretation. This is to some extent suggested by a study of Anderson et al. ${ }^{19}$ in which the readers had the possibility of mutually assessing the results of the screening mammograms: the sensitivity increased by $10 \%$ but the specificity decreased by only $2 \%$.

As expected, in the present study the sensitivity of double reading compared with single reading increased at the cost of a dlecrease in specificity (Table 1), but the Odds Ratio improved only slightly ( $44 \%)$. Sensitivity in dual reading was higher than in single reading and there was no decrease in specificity. This led to an increase of $14 \%$ in the OR. This result can also be explained by loss of concentration or the fact that this process of mutual adjucation does not occur in a routine examination.

In conclusion, the results of this study show that the improvement in accuracy by providing previous films and clinical information is negligible. With double reading, the sensitivity increases at the cost of the specificity, as the OR changes by $4 \%$. Dual reading increases sensitivity but hardly influences specificity, resulting in a slight increase of the OR by $14 \%$. Additional clinical information, previous radiographs, double or dual reading all have little impact on the detection of lung cancer on the chest radiograph, presumably because it is a routine procedure.

\section{References}

1. Austim J, Romney B, Goldsmith LS. Missed bronchogenic carcinoma: radiognaphic findings in 27 patients with a potentially resectable lesion evident in retrospect. Radiology 1992; 182: 115-122.

2. Forrest $J V$, Friedmann PJ. Radiologic arrors in patients with lung cancer. West $J$ Med 1981; 134 : 485-4.90.

3. White CS, Romney $B M$, Mason $A C$, et al. Primary carcinoma of the Lung Overlooked at CT: Anallysis of Findings in 14 patients. Radiology 1996; 199: $109-115$.

4. Guiss LW. Kuenstler P. A retrospective review of survey photofluorograms of persons with lung cancer. Cancer $1960 ; 13 ; 91-95$.

5. Muhm JR, Miller WE, Fontana RS, et al. Lung cancer detected during a screening program using fourmonth chest radiographs. Radiology $1983 ; 148: 609-615$.

6. Heelan RT, Fllehinger BJ, Melamed MR, at al. Non-small-cell lung cancer: results of the New York screening program. Radiology $1984 ; 151: 289-293$

7. Quekel LGD, Kesseis $A G H$, Goen R, et al. Miss rate of lung cancer on the chest radiograph in cinical practice. Chest 1999;115:720-724.

8. Brogdon BC, Kelsey CA, Moseley RD. Factors affecting perception of pulmonary lesions. Radiol Clin North An 1983; 21:633-665.

9. Woodring JH. Pitfalls in the Radiologic diagnosis of lung cancer. AJR $1990 ; 154: 1165-1175$

10. Herman $P G$, Gerson DE Hessel SJ, et al. Disagreements in chest roentgen unterpretation. Chest $1975 ; 68: 278-282$

11. Berbaum KS, Fianken EA, Dorfman DD, at al. Tentative diagnoses factitate the detection of diverse lesions in chest radiographs. Invest Radiol. 1986; 21:532-539.

12. Schreiber MH. The clinical history as a factor in roentgenogram interpretation. JAMA 1963; 185: $137-139$

13. Doubllet P. Harman PG. Interpretation of radiographs: Effect of clinical history. AJR 1981: 137: $1055-1058$.

14. Tudor GR, Finlay D, Taub N. An assessment of inter-observer agreement and accuracy when reporting plain radiographs. Clin Radiol 1997; 52: 235-238.

15. Berbaum KS. Franken EA, Dorfman DD, et al. Influence of clinicall history on perception of abnormalties im pediatric radiographs. Acad Radiol 1994; 1 : $217-223$.

16. Eldevik OP. Dugslad $G$, Orrison WW, al. The effect of clinical bias on the interpretation of myelography and spinal computed tomography. Radiology $1982 ; 145: 85-89$.

17. Good BC, Cooperstein LA. De Marino $\mathrm{GB}_{\text {n }}$ al al. Does knowledge of the clinical history affect the accuracy of chest radiograph interpretation? AJR 1990; 154:709-712.

18. Crallaway MP, Boggis CRM. Astley SA, et al. The influence of previous fillms on screening mammographic interpretation and delection of breast carcinoma. Clin Radiol 1997; 52: $527-529$. 
19. Anderson EDC, Muir $B B$, Walsh $J S_{\text {, }}$ et al. The efficacy of double reading mammograms in breast screening. Clin Radiol 1994; 49: 248-251.

20. Thurfjell E. Mammography screening one versus two views and independent double reading: Acta Radial 1994; 35: 345-349.

21. Warren RML. Duffy SW. Comparison of single reading with double reading of mammograms, and change in effectiveness with experience. Brit J Radiol 1995; 68: 958-962.

22. Thurfjell EL, Lernewall KA, Taube AAS. Benefit of independent double reading in a populationbased mammography screening program. Radiology 1994; 191: 241-244.

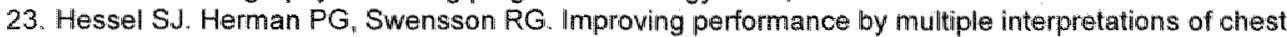
radiographs: Effectiveness and cost. Radiology 1977; 127: 589-594.

24. Beam CA, Sullivan DC, Layde PM. Effect of human variability on independent double reading in screening mammography. Acad Radial 1996; 3: 891-897.

25. Index for Radiological Diagnoses. 4th edition, Reston, Va: The American College of Radiology, $c$ 1992.

26. Potchen EJ, Gard JN, Lazar P, et al. The effect of clinical history data on chest film interpretation: direction or distraction. Invest Radiol 1979; 14: 404.

27. Swensson $\mathrm{RG}_{1}$ Hessel S.l, Herman PG. The value of searching films without specific preconceptions. Invest Radiol 1985; 20: 100-107.

28. Berbaum KS, Franken EA, Dorfman DD, et al. Influence of clinical history upon detection of nodules and other lesions. Invest radiol 1988; 23: 48-55. 
Chapter 5

Missed lung cancer in clinical practice: radiologic characteristics on the plain chest radiograph

(Pictorial review)

Quekel LGBA, Goei R 


\section{Abstract}

The diagnosis of early lung cancer on the chest radiograph may be troublesome, and failure to detect it has become one of the most frequent causes of missed diagnosis in radiology.

lung cancers presenting as small nodular lesions are missed because of poor lesion conspicuity as a result of superposition of hilar and mediastinal structures, blood vessels and bony structures. In a recent retrospective study over a four-year period including 380 patients, we found a $19 \%$ miss rate of lung cancers on the chest radiograph.

In this pictorial review, we provided an overview of the radiologic characteristics of missed lung cancers presenting as nodular lesions on the chest radiograph.

Key words lung neoplasms, diagnosis. Thorax, radiography. Thorax, neoplasms. Thorax, abnormalities. 


\section{Introduction}

Failure to detect lung carcinoma at an early stage on the chest radiograph is an acknowledged problem in Radiology and the generally accepted error rate has been estimated in the literature to be between $20 \%$ and $50 \%$. Missing a carcinoma of the lung on the chest radiograph often causes a serious delay in diagnosis and has also a negative effect on the prognosis. Many reasons have been given in the literature for missing lung cancer on the chest radiograph. These reasons include inadequate observation or interpretation and too short observation time, intentional and unintentional under-reading, technically poor images or poor viewing conditions as well as poor lesion conspicuity. ${ }^{2-6}$ Poor lesion conspicuity, resulting from superposing structures such as ribs, clavicles, vessels, hilar or mediastinal structures, or the small size and irregular shape of the lesion, are the most common reasons for missing the lesion on the chest radiograph.

The aim of this pictorial review is to provide an overview of the radiologic characteristics and findings of missed carcinoma of the lung presenting as small nodular lesions on the chest radiograph. The chest radiographs of patients with missed lung cancer were obtained after reviewing all chest radiographs of all consecutive patients with histopathologically proven lung cancer during the period 1992 through 1995 in a large community hospital. Of the 380 patients with carcinoma of the lung, 259 presented with a nodular lesion on the chest radiograph. By consensus, two radiologists who reviewed all the chest radiographs, it was concluded that in 60 patients the lesion seemed to have been missed radiologically. After consensus with a third radiologist, who reviewed all radiographs, it was decided that in 49 of the 259 patients $(19 \%)$ the nodular lesion was visible without doubt and had definitely been missed. ${ }^{7}$

\section{Location of missed lesions}

According to a large study by Theros, approximately $65 \%$ of lung cancers presenting as nodular lesions are located peripherally and $60 \%$ of all peripheral lesions are located in the right lung. In our group of 49 missed lung carcinoma patients, 27 $(55 \%)$ had peripheral lesions and 32 of the 49 missed lesions (63\%) were located in the right lung. These findings are also in accordance with the findings by Muhm et al. An explanation for the fact that more lesions are located in the right lung could be that the right lung is larger than the left lung and therefore has more chance of developing lung cancer. The result is that lung cancer is more often missed on the right side than on the left. According to Theros, ${ }^{8}$ the majority of the peripheral lung cancers $(60 \%)$ are found in the upper lobes, $30 \%$ in the lower lobes and $10 \%$ in the middle lobe and lingula. Of the 49 missed lesions in our study, $31(63 \%)$ lesions were located in the upper lobes, $18(37 \%)$ in the lower lobes but none in the middle lobe or lingula.

Not surprisingly, as most lung cancers are located in the upper lung zones, the most of the undetected lung carcinomas were also located there. These findings agree with those of Austin et al. ${ }^{2}$ Missing more lesions in the upper labes may be explained by the unawareness of many radiologists of the upper lobe predominance of lung carcinoma, which can cause underreading of the upper lobes. About $35 \%$ of lung cancers are located centrally and $50 \%$ of the undetected lung cancers are also located centrally. In our group of 49 patients with missed lung cancer, $22(45 \%)$ had lesions which were located centrally i.e. in the hilar or parahilar region (within $3 \mathrm{~cm}$ of the center of the hilus). An explanation for the fact that although one third of the 
lesions are located centrally, nearly half of the missed lesions are located there, could be that the lesion (or a part of it) is obscured by hilar structures and therefore can be easily missed. Also the lack of knowledge of the normal and abnormal hillar anatomy and the failure of the interpreting radiologist to compare the patient's previous radiographs with the new ones could be an explanation for the relatively high rate of missing centrally located lesions.

\section{The relationship between the size of the lesion and the chance of it being missed}

To be detectable, a lung lesion must grow large enough to be distinguishable from the normal surrounding structures. Kelsey et al ${ }^{6}$ found an accuracy rate of $44 \%$ for detecting lesions between 1 and $1.5 \mathrm{~cm}$ in diameter, but of only $8 \%$ when the lesions measured $0.5 \mathrm{~cm}$. The size of missed lesions can vary greatly. Muhm et al. ${ }^{9}$ found sizes of missed lesions ranging from $0.8 \mathrm{~cm}$ to $7 \mathrm{~cm}$ with an average size of $2.4 \mathrm{~cm}$. In our study, the sizes of the missed lesions varied between $0.5 \mathrm{~cm}$ and $7 \mathrm{~cm}$, but most were within the range of 2 to $5 \mathrm{~cm}$. Only $28 \%$ of the missed lesions had a diameter of $1 \mathrm{~cm}$ or less. The mean diameter of the missed lesions in the present study was $1.8 \mathrm{~cm}$, comparable with the results of Austin et al. ${ }^{2}$ who found a mean diameter of $1.6 \mathrm{~cm}$.

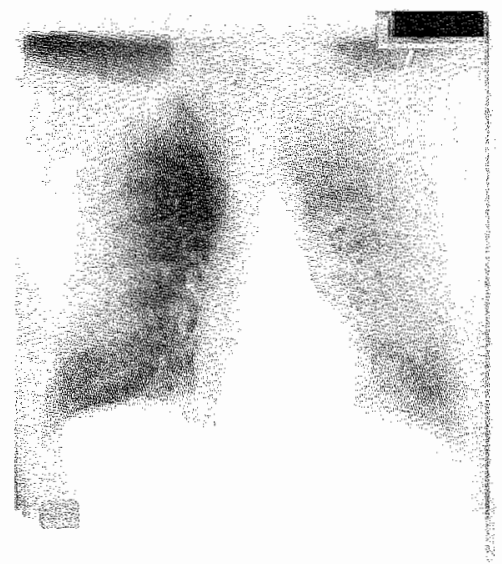

A. A previous chest radiograph without a malignant lesion for comparison

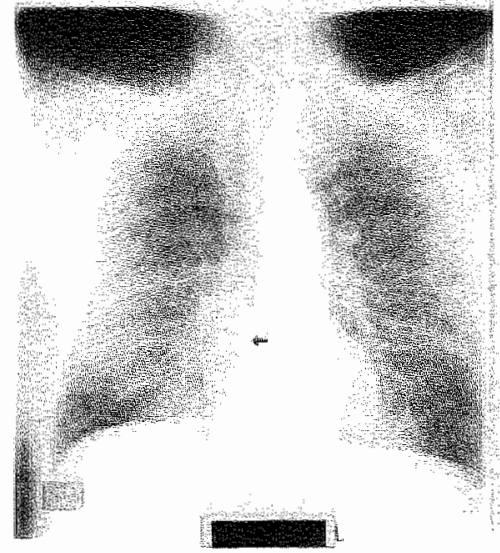

B. A chest radiograph five years later with a centrally located malignant lesion with a diameter of 2 by $4 \mathrm{~cm}$ in the vicinity of the right hilus (arrow)

Figure 1 A hilar lesion in a 78 year old man, missed because of superposing hillar structures.

Missed central lesions were larger than missed peripheral lesions, with mean sizes of 2.8 and $1.6 \mathrm{~cm}$ respectively. This was confirmed by Muhm et al. ${ }^{9}$ and can be explained by the fact that lesions are often hidden by hilar or mediastinal structures and are only discovered when they grow large enough to distort the configuration of these structures.

\section{The influence of growth on detection}

There are no reliable radiographic criteria that can distinguish benign from malignant lesions with high degree of confidence. One method to attempt to make the 
distinction is radiographic follow-up in order to determine if the lesion grows.

However, there are large differences in growth rates as shown by Muhm et al. who found, especially, that the peripherall llesions only grew slowly and approximately $9 \%$ showed a fairly consistent radiographic pattern on subsequent radiographs over several years of follow-up. Centrally located tumors showed more rapid enlargement of hilar or mediastinal nodes and therefore were detected earlier. In our study, $24.5 \%$ of the missed lesions had a delay of more than two years before diagnosis because of the slow growth over several years. This makes the detection of interval growth difficult and implies that a very slowly enlarging tumor might be considered benign and so be missed as a malignant lesion for several years. (Figures $2 a, b, c$ ), leading to considerable delay in diagnosis and treatment.

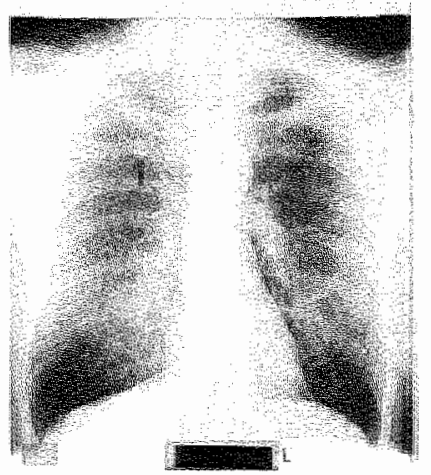

A February 1990, lesion size 0.5 by $1.2 \mathrm{~cm}$ (arrow)

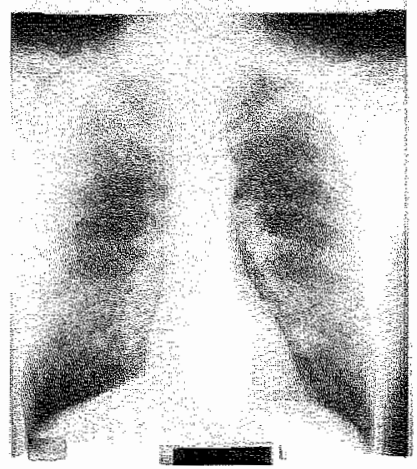

B July 1992 , lesion size 0.7 by $1.3 \mathrm{~cm}$

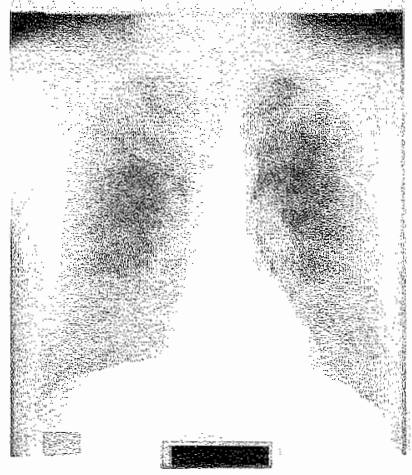

C. March 1994, lesion size 0.8 by $1.7 \mathrm{~cm}$

Figure 2. A very slow growing lesion visible on the chest radiograph in a 53 year old man, located in the right upper lobe, showing hardly any change in size and shiape over several years and missed over a period of more than four years. A selection of three chest radiographs out of six consecutive ones.

The influence of opacity, shape and border characteristics on the detection of lesions

Configuration of the margin of the lesion is important since nodular lesions with well demarcated, smooth edges and a relatively high density compared with the surrounding structures are identified earlier, more frequently, and with higher confidence levels than nodular lesions with irregular ragged edges and with a density hardly different from the surrounding structures (Figures 3 and 4 ). 


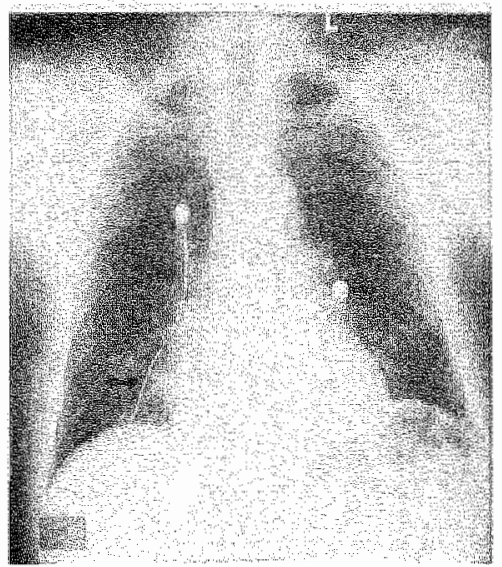

Figure 3. A missed early lung cancer on a chest padiograph in a 72 year old man located in the right lower lobe, paracardially with a ragged irregular edge (arrow).

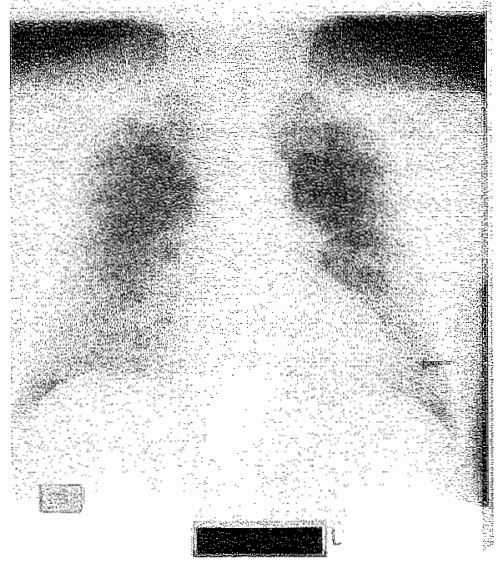

Figure 4. A missed malignant lesion on a chest radiograph in a 74 yealr old man located in the left lower lobe paracardially, with a diameter of $3 \mathrm{~cm}$ with a low opacity, hardly different from the surrounding lung parenchyma and only partly obscured by the heart (arrow).

In a large series of peripheral lesions Theros $^{8}$ found that $30 \%$ of the peripheral lesions had a shaggy appearance, $25 \%$ were poorly defined masses and $45 \%$ had lobulated and sharp borders. On the contrary, in the 49 patients with missed carcinomas in the present study we found that $70 \%$ of the lesions were partly or totally unsharply bordered and that only $30 \%$ had sharp borders. Austin et al. ${ }^{2}$ found unsharp or partly blurred borders in as many as $95 \%$ of the missed lesions.

The influence of superposing structures on the detection of pulmonary lesions Perhaps the most important reason for missing a carcinoma of the lung presenting as a nodular lesion on the chest radiograph is poor lesion conspicuity. Conspicuity is a measure of the extent to which a lesion is distinguishable from surrounding structures that may impair visibility. Anatomic structures or pathologic processes may overlap a nodule, destroy the integrity of its boundaries and thus modify its appearance so that, in effect, it is no longer a nodule to the eye of the observer. In particular, in poorly penetrated areas of the lung such as subpleural areas, areas behind the dome of the diaphragm, behind the heart and in the paramediastinal area the low contrast differences between the lung lesions and the surrounding areas greatly hinder nodule detection. In the 49 patients in the present study, the missed lesions were superposed on to other structures such as spine, ribs, clavicles, sternum, hilar structures, vessels, the heart and the diaphragm in 33 cases. Six lesions $(12 \%)$ were obscured by pathology such as silicosis, resolving infiltrates or hematoma's after trauma and end-stage lung disease. Two third of the superposing structures were located in the upper lobes. Ribs were the most frequent cause of superposing structures, namely 9 of 33 , followed by hilar structures in 8 of the 33 . Superposing structures formed by the skeleton, such as ribs, clavicles, scapula, sternum, spine are shown in Figures 5-9. 


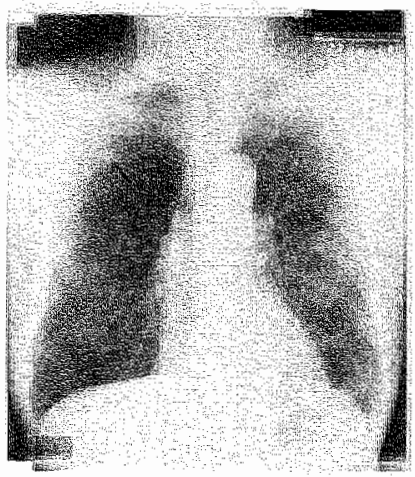

Figure 5. A missed malignant lesion on the chest radiograph in a 86 year old man. A rib is superposed on the lesion in the right upper lobe (arrow).

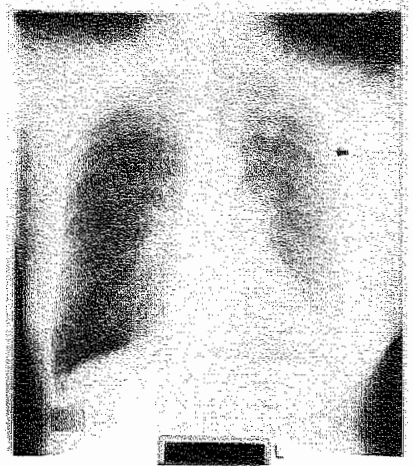

Figure 6. A missed malignant lesion on the chest radiograph in a 74 year old woman. The left scapula and part of a rib are superposed on the lesion in the left upper lobe (arrow).

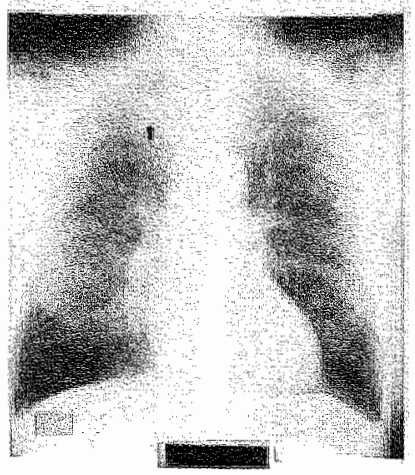

Figure 7. A missed malignant lesion on the chest radiograph in a 73 year old man. The right clavicle and part of a rib are superposed on the lesion in the right upper lobe (arrow).

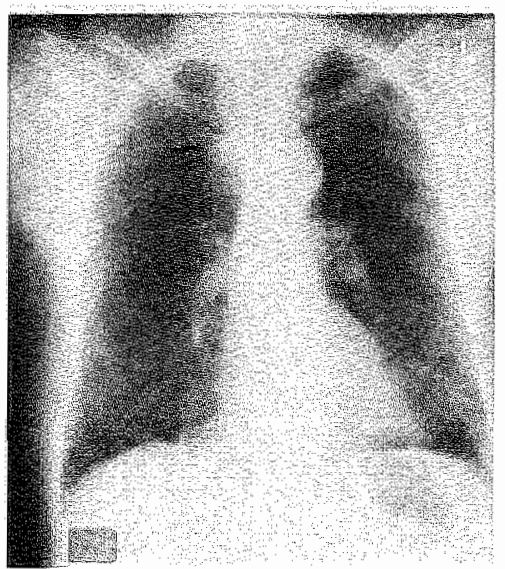

Figure 8. A missed malignant lesion on the chest radiograph in a 74 year old man. The right stemoclavicular joint is superposed on the lesion in the right upper lobe (arrow).

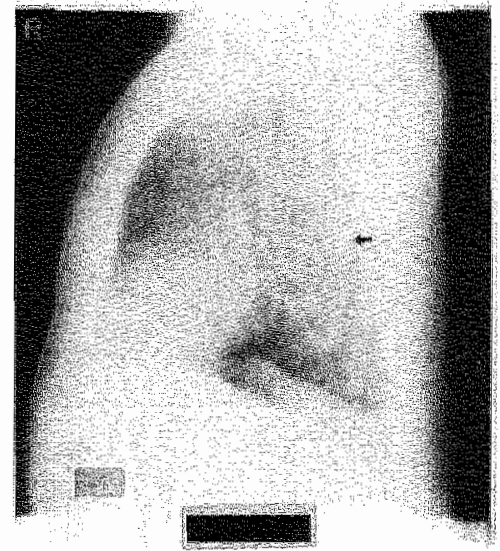

Figure 9. A missed malignant lesion on the lateral chest radiograph in a 67 year old man. The spine is superposed on the lesion in the left lower lobe (arrow). The lesion was not visible at all on the PA radiograph.

Superposing hilar structures are shown in Figure 1. whereas pulmonary vessels superposed on a lesion are shown in Figure 10. Figures 11 and 12 show superposing of heart and diaphragm and Figures 13-16 show four examples of pathologic conditions obscuring lung cancer, respectively: silicosis (Figure 13), a resolving infiltrate (Figure 14), a hematoma after trauma (Figure 15) and exlensive lung fibrosis in end-stage lung disease (Figure 16). 


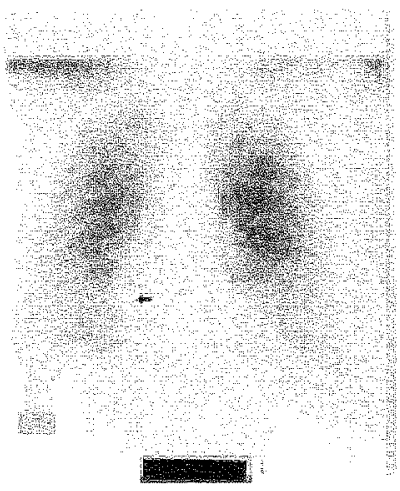

Figure 10. A missed malignant lesion on the chest radiograph in a 71 year old woman. Pulmonary vessels coming out of the right hilus are superposed on the lesion in the right lower lobe (arrow).

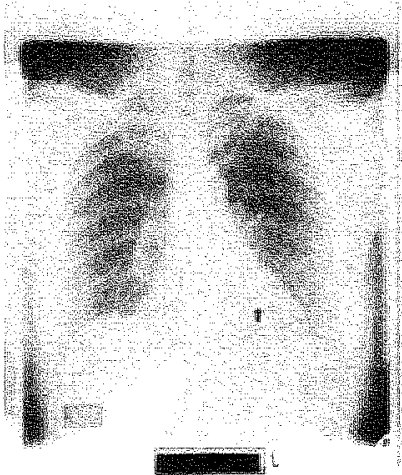

Figure 11. A missed malignant lesion on the chest radiograph in a 67 year old man. The heart is obscuring a lesion in the left lower lobe (arrow) which is hardly visible, despite a diameter of $2.5 \mathrm{~cm}$.

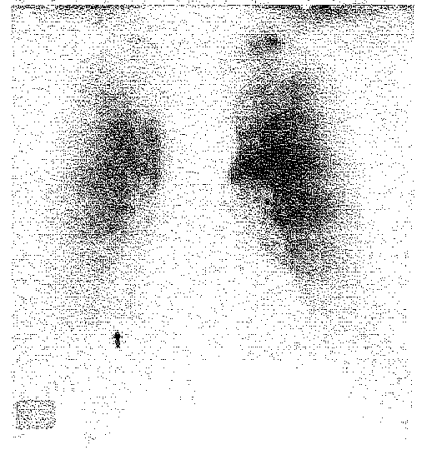

Figure 12. A missed malignant Iesion on the chest radiograph in a 63 year old man. The right hemidiaphragm is superposed on a lesion in the right lower labe with a diameter of $3.5 \mathrm{~cm}$ (arrow).

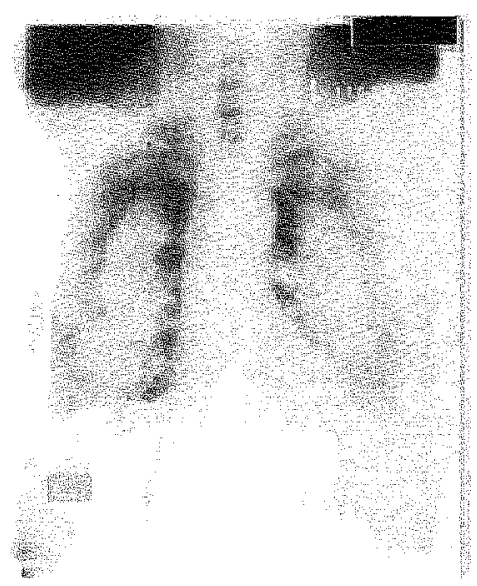

A. A previous chest radiograph with extensive sillicotic disease as described without a malignaint lesion.

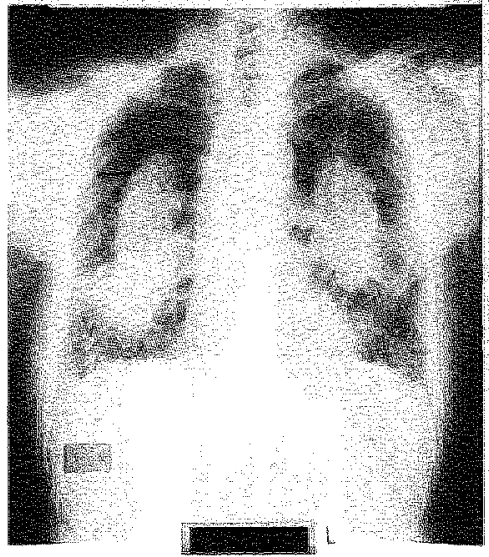

B. A chest radiograph taken 24 months later with the subpleural malignant lesion in the right upper lobe (arrow).

Figure 13. A malignant subpleural lesion in a 77 year old man, missed because the extensive interstitial reliculonodular lesions and the pseudotumoral masses are distracting the attention from the tumor in the right upper lobe. 


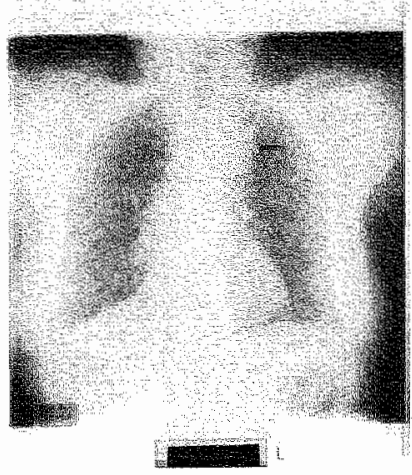

A. The chest radiograph with the infiltrate in the left upper lobe obscuring the tumor (arrow).

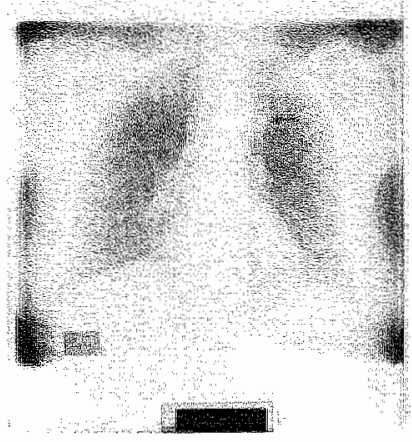

B. A chest radiograph taken three weeks later with the resolved infiltitate and the missed lesion paramediastinally (arrow).

Figure 14.- A malignant lesion in the left upper lobe in a 84 year old woman, missed because a resolving infiltrate is obscuring the tumor in the left upper lobe.

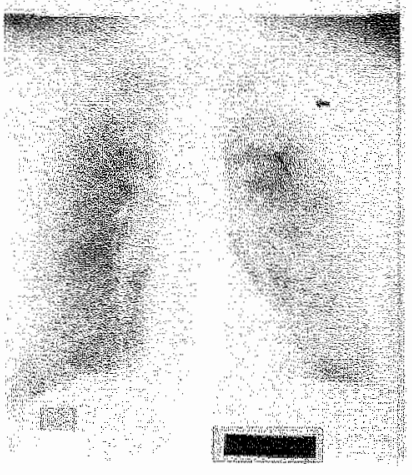

Figure 15. A malignaint lesion visible on the chest radiograph in a 7.4 year old man, missed because a resolving hematoma (horizontal arrow) after trauma is masking the presence of the lesion in the left upper lobe (oblique arrow).

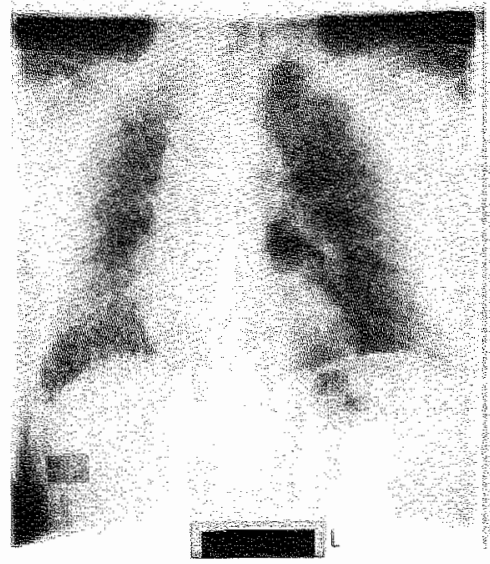

A. A previous chest radiograph with extensive abnormalities as described without a malignant lesion.

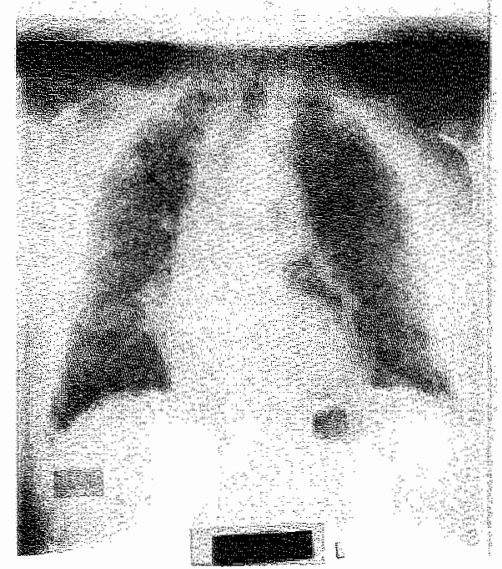

B. A chest radiograph taken 31 months later with a peripherally located tumor in the right upper lobe (arrow).

Figure 16. A peripheral malignant lesion in a 79 year old man, missed because extensive interstitial fibrosis in end-stage lung disease is obscuring the tumor in the right upper lobe.

\section{Usefulness of routinely obtaining both posterior-anterior and lateral chest radiographs in detecting pulmonary lesions}

The necessity of routinely obtaining a lateral as well as a posterior-anterior chest radiograph is often the subject of discussion. Some authors ${ }^{2,9}$ identified $3-4 \%$ of lung cancers only on the lateral chest radiographs and $5-27 \%$ of the lesions were better visible on the lateral chest radiograph than on the PA. In contrast. Forest and Sagel ${ }^{10}$ found all lung cancers on the PA chest radiographs and only $3 \%$ of the lesions were better visible on the laterals. In our study, 3 of the $49(6 \%)$ missed lesions were only 
visible on the lateral chest radiographs because superposed structures made the lesions invisible on the PA radiographs (Figure 17).
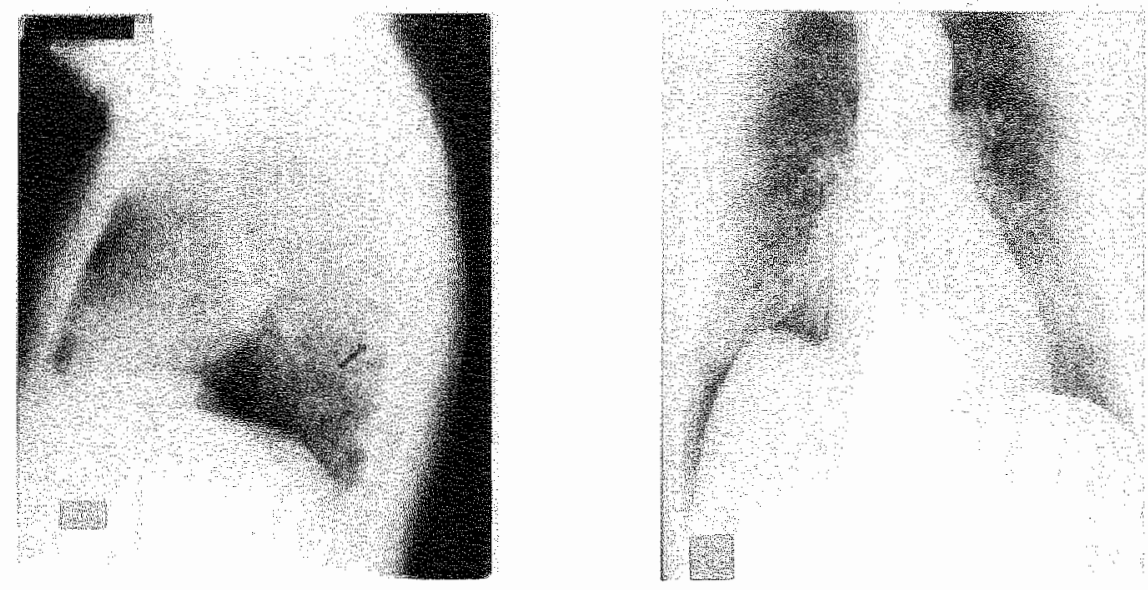

Figure 17 .- A missed malignant lesion on the chest radiograph in a 76 year old man, located in the left lower lobe, only visible on the lateral chest radiograph (arrow) and not visible at all in the posterioranterior chest radiograph.

Despite the minor yield of the lateral chest radiographs, we think they are necessary not only for detecting a lesion but also for localizing it within the different lung lobes.

\section{Reasons for repeatedly missing a lesion in the same patient}

In 16 of the $49(33 \%)$ patients the lesion was missed on two occasions on consecutive chest radiographs and in 6 of the $49(12 \%)$ even three times or more. The most frequent reason for missing a lung carcinoma on three or more consecutive chest radiographs was that the lesion was small and only grew slowly over several years (Figure 2). Other frequent reasons were silicosis with multiple interstitial reticulonodular lesions and conglomerates obscuring the tumor.

\section{Conclusion}

The diagnosis of early non small cell lung cancer on the chest radiograph may be troublesome and failure to detect lung cancer on the chest radiograph is one of the most frequent causes of missed diagnosis in radiology with a "miss rate" of approximately $20 \%$. When radiologists are aware of the various pitfalls, perhaps the miss rate can be lowered.

\section{References}

1. Woodring Jhil. Pitfalls in the radiologic diagnosis of lungcancerv. AJR 1990; 154: 1165-1175.

2. Austin JHM. Romney BM, Goldsmith LS. Missed bronchogenic carcinoma: fadiographic findings in 27 patients with a potentially resectable lesion evident in retrospect. Radiology 1992; 182: $115-122$.

3. Brogdon $B Q_{1}$ Kelsey CA, Mosely RD. Factors affecting perception of pulmoniary lesions. Radiol Clin North Am 1993; 21:633-665.

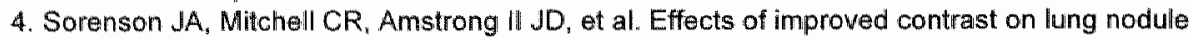
detection: a clinical ROC study. Invest Radiol 1987; 22: 772-780. 
5. Kundell HL, Nodine CF, Krupinski EA. Searching for hung nodules: wisual dwell indicates locations of false-positive and false-negative decisions. Irvest Radiol 1989:24: 472-478.

6. Kelsey CA, Mosely RD, Brogdon BG et all. Effect on size and position on chest lesion detection. AJR 1977; 129: 205-208.

7. Quekel LGB. Kessels AGH, Gaei $R$ et al. Miss rate of Jungcancer on the chest radiograph in dimical practice. Chest 1999; 115: 720-724.

8. Theros EG. Varying manifestations of peripheral pulmonary neoplasms: A radiologic-pathologic correlative study. AnR 1977; 128: 893-914.

9. Muhm JR, Miller WE, Fontana RS et al. Lung cancer detected during a screening program using four-month chest radiographs. Radialogy 1983; 148: 609-615.

10. Forrest JV. Sagel SS. The lateral radiograph for early diagnosis of lung cancer. Radiology 1979 131: 309-310. 

Chapter 6

Diagnostic performance of the chest radiograph and chest CT in the detection of lung cancer: A review*

Kessels AGH, Quekel LGBA, Goei R, van Engelshoven JMA 


\begin{abstract}
Purpose. To review the literature concerning the diagnostic performance of the chest radiograph and the chest $C T$ in the detection of lung cancer.
\end{abstract}

Material and methods. For the chest radiographs all articles published since 1980 and for the chest CT all articles since 1985 were retrieved both in Medline and PUB med. The papers had to be originals studies, ultimately histology or cytology was used as the standard of reference and the articles had to be published in English, German or Dutch. The gold standard was abtained by pathological proof following the diagnostic examinations or follow up of at least one year. If possible, for each study the prevalence, sensitivity, specificity, positive predictive value and negative predictive value were calculated.

Results. The search procedure yielded 20 articles which met the inclusion criteria: eight studies concerned a screening population and 12 studies clinically suspected patients. The studies included three types of diagnostic evaluations: evaluation of the chest radiograph, chest $\mathrm{CT}$ and chest $\mathrm{CT}$ in patients with a lesion on the chest radiograph. Sensitivities of the chest radiographs ranged from $26 \%$ to $81 \%$ and specificities varied between $85 \%$ and $99,6 \%$. For the chest CT after a positive chest radiograph sensitivity ranged between $88 \%$ to $100 \%$ and specificity varied between $70 \%$ and $100 \%$. For chest CT anly one study was found meeting the inclusion criteria, in this study the sensitivity was $68 \%$ and the specificity was $83 \%$.

Conclusion. The detection rate with chest $\mathrm{CT}$ is significantly higher than with the chest radiograph, suggesting that in all patients with symptoms which are suspicious of lung cancer, a chest CT should be performed. A diagnostic trial to assess the effect of screening with CT in a high risk population should be considered. 


\section{Intraduction}

Lung cancer is the leading cause of mortality due to malignancy in the United States and Japan and its incidence is still increasing. Non-small cell lung cancer represents $80 \%$ of all malignancies in the lung. For decades the detection of lung cancer has relied on the chest radiograph followed by sputum cytology, bronchoscopy or histology and radical surgical resection remains the only accepted curative treatment. Because non-small cell lung cancer develops between the ages of 40 and 80 years and shows a high incidence in heavy smokers, early detection in this group would have a high impact on survival. With this in mind, mass screening programs for the early detection of lung cancer were carried out in Japan. In the 1970s and the 1980s, randomized trials were performed in the United States to investigate the effectiveness of mass screening for lung cancer by way of periodical chest radiographs and sputum cytology. ${ }^{1}$ Straus et al. ${ }^{2}$ studied the usefulness of chest radiographic screening with sputum cytology for lung cancer in various trials. They concluded that there was a statistically significant reduction in mortality favoring the study group in the Mayo Lung Project. However, Heelan et al., ${ }^{3}$ in their study of the New York screening program, found that among those whose cancer was detected by annual chest radiography a substantial number $(65 \%)$ had evidence of tumor for several years. This implies a delay in detection and thus a poorer prognosis. Studying the Mayo Lung Project results Muhm et al. ${ }^{4}$ showed that peripherally located cancers grew slowly and $75 \%$ of the lesions in the population screened were visible in retrospect for months or even years. The central lesions grew rapidly, presenting as hilar or mediastinal enlargements. Of these, $65 \%$ had been missed on previous chest radiographs.

The results of screening with chest $X$-rays and sputum cytology are disappointing and the usefulness of screening for lung cancer with these modalities is controversial. However, since the introduction of low dose spiral Computed Tomography (CT) which lowers the radiation dose to an acceptable level, screening for lung carcinoma has gained in interest ${ }^{7,5}$

The chest radiograph is also used to detect lung cancer in hospitalized patients and outpatients. Unfortunately delayed diagnosis is common because radiologists often fail to detect small-sized lung cancers on the chest radiograph. Reasons for these include: technically poor images, poor viewing conditions and inaccurate screening the radiographs for the presence of lung cancer ${ }^{5}$. However, the most common reason is superposition of anatomical structures such as ribs, clavicles, vessels and hilar or mediastinal structures ${ }^{5}$. CT could be of use as CT is not hindered by superposition of anatomical structures and could depict lung cancers at an earlier stage. In addition, CT could characterize a lesion as being benign or malignant more reliably by depicting the anatomy of the lesion more clearly. Calcifications in a small smooth-edged lesion suggest that the lesion is benign. Larger non-homogeneous lesions with a spiculated contour or lobulations are likely to be malignant. ${ }^{6}$ It is generally assumed that $\mathrm{CT}$ has a better diagnostic performance than conventional chest radiography in the detection of lung cancer.

As chest radiograph and chest CT are frequently performed radiological examinations and given the importance of the result of these tests, they have often been the subject of studies in the literature. However, to our knowledge, there has been no comprehensive study of the literature in order to investigate their diagnostic performance. 
The aim of this study was to systematically review the literature on empirical studies of the chest radiograph and chest CT performance in the detection of lung cancer. We distinguish between a screening setting and their use in daily clinical practice.

\section{Material and methods}

\section{Selection of studies on diagnostic validity of chest $X$-ray and chest $C T$}

Both in Medline and PUB med a search was performed to retrieve papers on the diagnostic performance of the chest $X$-ray and chest $C T$ in the detection and or evaluation of lung lesions suspected of being cancer. For the chest $X$-ray, all papers published since 1980 were retrieved and for chest CT, all since 1985 . The search terms used were: pulmonary nodules, lung neoplasms, carcinoma (non)-small-celllung, chest $X$-ray, tomography $X$-ray computed and mass-screening. In PUB med also the search function 'related articles' was used. Additional articles were obtained by citation tracking of review articles and original papers.

To be included the paper had to:

1. describe an original study.

2. use histology or cytology as the standard of reference.

3. focus on a screening population or clinically suspected patients.

4. be published in English, German or Dutch.

\section{Data extraction}

A standard form was used to extract the data from the studies included. The first author, the year of publication, the test techniques, the population characteristics and the test performance were included. Furthermore, we recorded the method by which the gold standard for the chest radiograph or CT was obtained: pathological proof by biopsy, cytology or surgical specimen directly following the diagnostic examination or after a follow-up of at least one year. Also recorded was whether each study was prospective or retrospective.

\section{Study population}

For each study, we recorded the size and composition of the study group i.e. patients clinically suspected of having lung carcinoma or a screening population, whether or not high risk. Furthermore, for each study population mean age and gender distribution were recorded.

\section{Test techniques}

A distinction was made between studies which evaluated the diagnostic performance of the plain chest $X$-ray, those evaluating chest CT and studies evaluating both chest $X$-ray and chest CT. For CT, it was also documented whether the study concerned conventional CT, dynamic contrast enhanced CT or HR-CT.

\section{Test performance}

For all studies, if possible, a crosstable of the test vs. the standard of reference was constructed. From this table, prevalence, sensitivity, specificity, positive predictive value (PPV) and negative predictive value (NPV) were calculated. 


\section{Results}

The search procedure yielded 45 articles. Of these, ten did not fulfil the inclusion criteria. The most important reason for exclusion was the lack of cytology or histology as the standard of reference. Another reason was that in the presentation of the results no distinction was made between different types of lung cancer and/or non-mallignant pathology. Additionally 10 articles were excluded from this meta analysis: 5 articles ${ }^{3-4,32,37-3.8}$ were preliminary reports of original studies and 5 articles $^{2,33-36}$ evalluated or processed the results of original studies. The remaining 25 articles concerned 20 studies as in some investigations the diagnostic parameters and the result of clinical follow-up were presented in separate articles. We checked for overlap between the study data. The various studies and their characteristics, ranked by year of publication, are presented in Table 1.

The studies included three types of diagnostic evaluations: evaluation of the chest radiograph, evaluation of the chest CT and evaluation of the chest $C T$ in patients with a lesion on the chest radiograph.

Table 1. Study characteristics.

\begin{tabular}{|c|c|c|c|c|c|c|c|}
\hline $\begin{array}{l}\text { No First auttuor } \\
\text { (referemce) }\end{array}$ & Vear & $\begin{array}{l}\text { Test" } \\
\text { modalities }\end{array}$ & Population ${ }^{\text {ta }}$ & $\begin{array}{l}\text { Size of } \\
\text { study }\end{array}$ & $\begin{array}{l}\text { Mean } \\
\text { Age }\end{array}$ & \% & $\begin{array}{l}\text { Gold at } \\
\text { Standand }\end{array}$ \\
\hline "1 veldhuizem (17) & 1980 & $x$ & Review lesions & 185 & $?$ & 90 & $P A+F U$ retrospl \\
\hline 2 Hayabuch $(30)$ & 1983 & $x$ & Lung carcinoma & 107 & $?$ & 62 & $P A+F(n)$ (retrosp) \\
\hline 3 Fontana $(11.12)$ & 1984 & $x+5 p$ & S, smokers, male, $>45$ yr. & 10.111 & ? & 100 & $P A+F U$ \\
\hline 4 HEl Hehruger $(13,94)$ & 1984 & $x+5 p$ & S, snokers, male, $345 \mathrm{yr}$ & 11,040 & $?$ & 100 & $P A+F$ \\
\hline 5 FHost $(15,16)$ & 1984 & $x+s p$ & S, smokers, male, $\geq 45$ yr. & 90,387 & $?$ & 100 & $P A+\mathbb{E}$ \\
\hline 6 Kubic $(28,29)$ & 1986 & $x+5 p$ & 5 male, $>40$ ym. & 3,172 & $?$ & 100 & $P A+F U$ \\
\hline 7 Naidich $(25)$ & 1988 & $\mathrm{CT}$ & Lung carcinoma & 55 & $?$ & $?$ & $P A+F U(r e t r o s p)^{6}$ \\
\hline 8 hittleton $(20)$ & 1990 & D.CT & Lesion on chest radiagraph & 46 & $?$ & $?$ & $P A+F U$ \\
\hline 9 Zwirewich (18) & 1991 & $\mathrm{HPR} \times \mathrm{CT}$ & Lesion on chest radiograph & 93 & 64 & 52 & $P A$ \\
\hline 10 Soda $(10)$ & 1993 & $x$ & 5. $240 \mathrm{yr}$ & 205.401 & $?$ & $?$ & $P A+F U(r e t r o s p)^{s}$ \\
\hline 11 hrimack $(24)$ & 1994 & $H P_{R}-C T$ & Lesion on CT & 349 & 64 & 61 & $P A+F U$ \\
\hline 12 Yamashila (19): & 1995 & D.GT & Lesion $<3 \mathrm{~cm}$ an chest radiograph & 32 & 58 & 60 & $\mathrm{PA}$ \\
\hline 13 Swenser $(20)$ & 1995 & $\mathrm{D}-\mathrm{CT}$ & Lesion on $\mathrm{D}-\mathrm{CT}$ & 163 & 63 & 58 & $P A+m U$ \\
\hline 14 Kaneko $(7.8)$ & 4996 & $X+C T+S p$ & S, smokers; $>45 \mathrm{yr}$ & 3,457 & 60 & 90 & $P A+F U$ \\
\hline 15 Swensen $(22)$ & 1996 & Q D.C.T & Lesion on $\mathrm{CT}$ & 99 & 62 & 53 & $P A+F U$ \\
\hline 16 Zhang $(21)$ & 1997 & $\mathrm{D}-\mathrm{C} \mathrm{T}^{\mathrm{T}}$ & Lesion on chest radiograph or $\mathrm{CT}$ & 65 & 64 & 82 & $\mathrm{PA}+\mathrm{PU}$ \\
\hline 17 Latief $(27)$ & 1997 & X $\rightarrow>0$ & Brair metas from lung cancer & 32 & 57 & 78 & $P A$ \\
\hline 16 Hori $(23)$ & 1997 & $x \rightarrow \mathrm{CT}^{-}$ & S, no inciusion criteria & 5,437 & 54 & 30 & $P A$ \\
\hline 19 Henschise $(9)$ & 1990 & 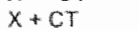 & S. shokers & 1.000 & 67 & 54 & $P A$ \\
\hline 20 ouekel $(31)$ & 1999 & $x$ & Lesion on chest radiognaph & 259 & 89 & $\gamma B$ & $P A+F U$ iretrospl \\
\hline
\end{tabular}

\footnotetext{
5. $X=$ Chest radiograph, CT $=$ Chest Computed Tomagraphy, HR CT $=$ CT fallowed by High Reschwhon CT if hT ghowed stispected lesion, D-CT = Dymamic (contrast enhanced Chesl CT, Sp = Sputum cytolocy

W $S=$ Screwening population

at: $P A_{n}=$ Pathological histological or cytological) proof of lung cancer. Fu - Follov Up of at leagr one year

s: Lurg cancers were retrospectively collected from cancer registries

4: Chest radiograph followed by CT if radiograph showed suspect lesion
}

The diagnostic parameters of studies are presented in table 2. Kaneko (no. 14), Latief (no. 17) and Mori (no. 18) evaluated both the chest X-ray and the CT and as a result are mentioned twice in this table.

The sensitivities are derived from the number of false negative results. These numbers have been determined in two different ways. In all but two of the studies a follow-up period of at least one year, whether or not combined with the result of the sputum cytology, was taken in order to determine the number of false negative results. As standard of reference for the chest radiograph, Henschke (no 19) used 
CT with pathological confirmation and Kaneko (no 14) used CT with pathological confirmation as well as a follow-up period of one year.

If the data resulted from a screening program we calculated the diagnostic parameters from the prevalence rates, i.e. the results of the first screening examination. In the studies of Soda (no. 10) and Kaneko (no. 14) this was not possible as the presented results were based on multiple examinations per patient. In four screening studies (nos. 3, 4,5 and 6) the follow-up data are extracted from the one-year interval cancers. Flehinger (no. 4) and Frost (no. 5) screened annually; as the average duration of the screening program was 6 years, the number of oneyear interval cancers was estimated by dividing the total number of interval cancers by 6 . Fontana (no. 3) used a 4-monthly program for 6 years and detected a total of 71 interval cancers. Dividing 71 cancers by 6 will result in an underestimation of the number of one-year interval cancers. Therefore, the number of one-year interval cancers was estimated from the data from the two sister screening projects (nos. 4 and 5 ); the estimates from these studies were 20 and 31 respectively and the average of the two studies was used for estimating the sensitivity. In the first three years of the program Kubic (no. 6) used a bi-annual screening in one group and a non-recurrent screening in the other; in the second three years period an annual screening procedure was used in both groups. The one-year interval estimate is based on the results from this second period.

Table 2. Prevalence and tesl performance; all parameters are in percentages

Prew. Sens. Spec. PPV NPV

\begin{tabular}{|c|c|c|c|c|c|}
\hline \multicolumn{6}{|l|}{ Chest radiograph } \\
\hline Veldhuizen (1980) & .. & - & $\infty$ & 68 & * \\
\hline Hayabuchi (1983) & - & 54 & - & - & . \\
\hline Fontana (1984) & 1.14 & 63 & 96 & 17.2 & 99.57 \\
\hline Flehinger (1984) & 0.70 & 61 & 88 & 3.6 & 99.69 \\
\hline Frost (1984) & 1,10 & 62 & 85 & 4.4 & 99.51 \\
\hline Kubic (1986) & 1.55 & 59 & 92 & 10.4 & 99.31 \\
\hline Soda (1993) & 0.10 & 70 & 99.6 & 13.2 & 99.97 \\
\hline Kaneko (1996) & 0.64 & 45 & 98.6 & 17.5 & 99.65 \\
\hline Latief (1997) & - & 59 & . & - & - \\
\hline Mori (1997) & - & - & . & 7.4 & - \\
\hline Henschke (1999) & 2.70 & 26 & 94 & 10.3 & 97.85 \\
\hline Quekel (1999) & - & 81 & $=$ & - & - \\
\hline \multicolumn{6}{|l|}{ Chest CT } \\
\hline Kaneko (1996) & 0.64 & 68 & 83 & 2.6 & 99.76 \\
\hline \multicolumn{6}{|c|}{ Chest $C T$ after pos "result of $X$-ray } \\
\hline Naidich (1988) & - & - & . & 91 & - \\
\hline Littleton (1990) & 52.2 & 88 & 95 & 96 & 87.5 \\
\hline Zwirewich (1991) & - & - & - & 88 & - \\
\hline Primack (1994) & 70.2 & 99.2 & 75 & 90 & 97.5 \\
\hline Yamashita (1995) & 54.8 & 100 & 100 & 100 & 0 \\
\hline Swensen (1995) & 68.1 & 100 & 77 & 90 & 0 \\
\hline Swensen (1996) & 44.4 & 98 & 73 & 74 & 97.6 \\
\hline Zhang (1997) & 64.6 & 100 & 70 & 86 & 0 \\
\hline Latief ( 1997 ) & - & 97 & - & . & - \\
\hline Mori (1997) & - & - & - & 15 & - \\
\hline
\end{tabular}


Veldhuizen (no. 1), Primack (no. 11) and Swensen (no. 15) included patients with metastasis and Naidich (no. 7) included patients without pathological confirmation. All these patients were excluded from this analysis.

Two studies presented their results based on lesions and not patients: Littleton (no.

8) used 46 lesions in 45 patients and Zwirewich (no. 9) used 93 lesions in 90 patients.

Sensitivities of the chest $X$-ray ranged from $26 \%$ to $81 \%$ and specificities varied between $85 \%$ and $99.6 \%$. For the $\mathrm{CT}$ after a positive result of the chest $X$-ray sensitivities ranged from $88 \%$ to $100 \%$ and specificities varied between $70 \%$ and $100 \%$.

\section{Discussion}

The purpose of the present review was to summarize the diagnostic performance of the chest $X$-ray and chest CT in the detection of lung cancer.

Although the search and selection of the studies was straightforward, the aggregation and interpretation of the data was not. This was caused by the wide variety of the criteria for patient or subject selection, test techniques used (in particular the CT), the way the gold standard was obtained and the method of data analysis. Furthermore "the data presented were often not unequivocally interpretable or (partly) missing.

We will discuss the diagnostic performance in two kinds of populations: 1) a screening population, whether or not consisting of high risk persons and 2) symptomatic or clinically suspected patients.

\section{Screening setting}

The clinical value of the chest radiograph or CT is ultimately determined not by its accuracy in detecting cancer but in combination with adequate therapy by its improvement of the prognosis. This is particularly important in a screening program where false positive results cause anxiety, advance the date of the diagnosis but have possibly no effect on life expectancy. Alternatively, cancers may be detected that would not have become manifest otherwise and unjustified reassurance by $a$ false negative result may cause patient delay. To compensate for the resulting losis of quality of life, proof of gain in clinical outcome, e.g. reduction in mortality, is obligatory. In the two randomized trials of Fontana ${ }^{12}$ and $\mathrm{Kubic}^{29}$ the morality rates of a group with and a group without screening by chest $X$-ray were compared. The number of cases detected 11 years after the start of the screening program in the study of Fontana was 206 in the screened and 160 in the control group and the numbers of lung cancer deaths were 122 and 115 respectively. In the study of Kubic the number of cases after 6 years was 108 in the screened group and 82 in the control group and the numbers of lung cancer deaths after 9 years were 85 and 67 respectively. This means that screening does not appear to influence lung cancer mortality (or only in a negative way). Furthermore, it appears that screening increases the incidence of lung cancer, indicating that in a certain number of lung cancer cases the patients are unnecessarily made aware of their disease. Therefore, screening with chest radiography alone cannot be advocated. This is in contrast with Straus et. al. ${ }^{2}$ whose conclusions are mainly based on the same studies, but who advance a reduction of mortality in the screened population.

Only Kaneko and Henschke ${ }^{5}$ used chest radiography and CT in all participants making a direct comparison of these test modalities possible. In Kaneko's study, the 
chest X-ray detected 10 and the CT 15 out of 22 lung cancers, resulting in sensitivities of $45 \%$ and $68 \%$ respectively. This suggests a better performance of CT. Henschke did not use a follow-up period to confirm a negative test result and detected 27 cases with CT of which 7 were detected by chest $X$-ray. Taking the CT as the gold standard the sensitivity of the chest $X$-ray was $25 \%$. It is remarkable that in the two studies in which CT was used parallel to the chest $X$-ray, the sensitivity of the chest radiograph was significantly lower than in the other screening studies where sensitivities varied between $59 \%$ and $70 \%$ (Table 2). This could mean that CT detects more lung cancers than become manifest in the follow-up period of one year as this is the period used in the latter studies to confirm a negative test result. Consequently, these extra cancers detected by CT are slow growing ones and should have the best prognosis. This result makes it justifiable to study whether screening only with CT would reduce mortality of lung cancer and this can only be performed with a randomized diagnostic trial.

\section{Clinical practice}

In daily clinical practice the chest $X$-ray is still the first radiological examination in patients with suspected lung cancer. If the chest $X$-ray is positive the chest CT is appropriate for diagnostic work-up. Table 2 shows that all studies from 1994 onwards reach CT sensitivities of almost $100 \%$. The decision what to do in case of a negative chest radiograph depends particularly on the miss rate, that is one minus the sensitivity. The sensitivities and specificities of the screening program as presented in table 2 are based on the results of the first round i.e. the detection of prevalent cases. Therefore, we think that these values can be used as an estimate in a clinical setting. As sclinically suspected patients are in a more advanced stage of disease than the high risk group in a screening program, these values will be an underestimation. Anyhow, the sensitivities in table 2 show that a substantial number of lung cancers are missed. As the patients with clinical symptoms are aware of possible lung disease a more aggressive diagnostic approach is defendable and a chest CT in these patients should be considered.

\section{Conclusions}

As two randomized trials ${ }^{12,29}$ showed, chest radiography is not expected to reduce mortality in a screening setting. As the detection rate with chest $\mathrm{CT}$ is significantly higher, a diagnostic trial to assess the effect of screening with $C T$ in a high risk population should be considered.

In all patients with symptoms which are suspicious of lung cancer a chest CT should be performed, regardless of the result of the chest radiograph.

\section{References}

1. Berlin N.I, Buncher C.R. Fontena R.S. Frost J.K. Melamed M.R. The National Cancer Institute Cooperatiwe Early Lung Cancer Detection Program. Results of the linitial Screening. Early Lung Cancer Detection: Introduction resp. Summary and Conclusions. Am Rev Respir Dis 1984; 130: $545-549$ resp. $565-570$.

2. Straus G.M, Gieason RE, Sugabaker DJ. Chest X-ray screening improves outcome in lung cancer Chest 1995: 107: 270s-279s.

3. Heelan RT, Flehinger BJ, Melamed MR ef al. Non-smal-cell lung cancer: results of the New York scirening program. Radiology 1984; $151: 289-293$.

4. Muhm JR, Miller WE, Fontana RS, Sanderson DR, Uhlenhopp MA. Lung Cancer Detected During a Screening Program Using Four Month Chest Radiographs. Radiology 1983; 148: 609-615 
5. Brogdon BG, Kelsey CA, Moseley RD. Factors Affecting Perception of Pulmonary Lesions. Radiol Clin N Am 1983; 21: 633-654.

6. Kuriyana K, Tateishi R, Doi O, et al. CT-Patholagic Correlation in Small Peripheral Lung Cancers. A.JR 1987; 149: 1139-1143.

7. Kaneko M. Eguchi K, Ohmatsu H, et al. Peripheral Lung Cancer: Screening and Detection with Low-Dose Spiral CT versus Radiography. Radiology 1996; 201: 798-802.

8. Kakinuma R, Onmatsu $H$, Kaneko $M$, et al. Detection Failures in Spiral CT Screening for Lung Cancer: Analysis of CT Findings. Radiology 1999; 212:61-66.

9. Henschke C, McCauley DI, Yankelevitz DF, el al. Early Lung Cancer Action Project: overall design and findings from baseline screening. Lancelt $1999 ; 354: 99-105$

10. Soda $H$, Tomita $H$, Kohno S, Oka M. Limitation of Annual Screening Chest Radiograph for the Diagnosis of Lung Cancer. Cancer 1993; 72" 2341-2346.

11. Fontana RS, Sanderson DR, Taylor WF, et al. Early Lung Cancer Detection: Results of the Initial (Prevalence) Radiologic and Cytologic Screening in the Mayo Clinic Study. Am Rev Respir Dis 1984; $130: 561-565$.

12. Fontana RS, Sanderson DR, Woolner LB, et al. Screening for Lung Cancer. A Critique of the Mayo Lung Project. Cancer 1991; 67: 1155-1164.

13. Flehinger BJ, Melamed MR, Zaman MB, et all. Early Lung Cancer Detection: Results of the Initial (Prevalence) Radiologic and Cytologic Screening in the Memorial Sloan-Kettering Study. Am Rev Respir Dis 1984; 130: $555-560$.

14. Melamed MR, Flehinger BJ, Zaman MB, Heelan RT, Perchick WA, Martini N. Screening for Early Lung Cancer. Results of the Memorial Sloan-Kettering Study in New York. Chest 1984; 86: 44-53.

15. Frost JK, Ball WC, Levin ML, et al. Early Lung Cancer Detection: Results of the Initial (Prevalence) Radiologic and Cytologic Screening in The Johns Hopkins Study. Am Rew Respir Dis 1984; 130: $549-554$.

16. Tockman MS. Survival and Mortality from Lung Cancer in a Screened Population. The Johns Hopkins Study. Chest 1989; 89 : $324 \mathrm{~s}$.

17. Veldhuizen WCJ, Herwaarden CLA van, Jongerius CM. Coin lesions op de thorax foto. Ned T Geneesk 1980; 124: 40-45.

18. Zwirewich CV, Vedall S, Miller RR, Muller NL. Solitary Pulmonary Nodule: High-Resolution CT and Radiologic-Pathologic correlation. Radiology 1991: 179: 469-476.

19. Yamashita $K_{n}$ Matsunobe S, Tsuda T, et al. Solitary Pulmonary Nodule: Preliminary Study of Evaluation with Incremental Dynamic CT. Radiology 1995; 194:399-405.

20. Swensen SJ, Brown LR, Colby TV, Weaver AL. Pulmonary Nodules:CT Evaluation of Enhancement with lodinated Contrast Material. Radiology 1995; 194: 393-398.

21. Zhang $M$, Kono $M$. Solitary Pulmonary Nodules: Evaluation of blood flow patterns with Dynamic $c T$. Radiology 1997; 205: 471-478.

22. Swensen S.I, Brown LR, Colby TV, Weaver AL, Midthun DE. Lung Nodule Enhancement at CT: Prospective Findings. Radiology 1996: 201: 447-455.

23. Mori K. Tominaga K, Hirose T, at Utility of Low-Dose Helical CT as a Second Step After Plain Chest Radiography for Mass Screening for Lung Cancer. J Thoracic Imaging 1997; 12: 173-180.

24. Primack SL, Lee KS, Logan PM, Miller RR, Muller NL. Bronchogenic Carcinama: Utility of CT in the Evaluation of Patients with Suspected Lesions. Radiology 1994: 193: 795-800.

25. Naidich DP, Sussman R, Kutcher WL, et al. Solitary Pulmonary Nodules. CT bronchoscopic Correlation. Chest 1988; $93: 595-598$.

26. Littleton JT, Durizch ML, Moeller $G$, Herbert DE. Pulmonary Masses: Contrast Enhancement. Radiology 1990; 177: 861-871.

27. Latief KH, White CS, Prolopapas Z. Attar S, Krasna MJ. Search for a Primary Lung Neoplasm in Patients with Brain Metastasis; Is the chest Radiograph Sufficient? AJR 1997; 168: 1339-1344.

28. Kubic A, Polak J. Lung Cancer Detection. Results of a Randomised Prospective study in Czechoslovakia. Cancer1986; $57: 2427-2437$

29. Kubic A, Parkin DM, Khlat M, Erban ل, Polak J. Adamec M. Lack of Benefit from Semi-Annual Screening for Cancer of the Lung: Follow-Up Report of a Randomized Controlled Trial on a Population of High-Risk Males in Czechoslovakia. Int J Cancer $1990 ; 45 ; 26-33$.

30. Hayabuchi N, Ruswell WJ, Murakani J, Nishitani H. Screening for Lung Cancer in a Fixed Population by Biennial Chest Radiograph. Radiology 1983; 148: 369-373.

31. Quekel LGBA, Kessels AGH, Goei R, van Engelshoven JMA. Miss rate of lung cancer on the chest radiograph in clinical practice. Chest 1999; 115: $720-724$. 



\section{Chapter 7}

\section{General discussion}

The detection of early lung carcinoma on the chest radiograph is known to be troublesome, especially when it presents itself as a small pulmonary nodule. In the United States this is the case in 1 of every 500 chest radiographs. "In our study presented in chapter 2, a miss rate of lung cancer presenting as a nodular lesion of $19 \%$ was found in daily clinical practice. In literature the miss rate varied between $25 \%$ and $90 \%{ }^{2-4}$ and in one study only $29 \%$ of the cancers in Stage 1 were detected. This miss rate is unacceptably high, especially taking into account that lung cancer at an early stage is a curable disease. According to the American Cancer Society estimates, the overall survival rate of lung cancer was $10 \%,{ }^{6}$ A recent summary of mine independent published series has shown that the pooled 5-year survival rate of early stage (pathological Stage 1) non-small-cell lung cancer was $70 \%$, much higher than the overall rate of $10 \%$ When a delay in detection occurs by missing the tumor at an early stage the prognosis declines rapidly as was found in our study: in $43 \%$ of the patients with a missed lung cancer on the chest radiograph the T stage changed from T1 to T2. According to Mountain ${ }^{B}$ the five-year survival rate drops in these patients from $61 \%$ to $38 \%$ assuming that the $\mathrm{N}$-status and the M-status remain unchanged. When the chest radiograph was the only radiological modality for detecting lung carcinoma, one had to accept this miss rate and its consequences. With the availability of the CT scan with its promising results the detection of lung carcinoma at an early stage ${ }^{9}$ a miss rate of $19 \%$ is no longer acceptable. This implies that in order to lower the miss rate, possible causes should be analyzed. Then, even more important "a method must be found to effectively lower the miss rate to an acceptable level. When this cannot be reached by improving the diagnostic performances of the chest radiograph itself or of its reviewers, then this radiological modality has lost its usefulness. In this case the diagnostic process needs to be changed and the CT of the chest, especially the low dose spiral CT, should replace the chest radiograph if this modality appears to perform better.

In the study presented in chapter 3 , the diagnostic performance of observers in detecting lung carcinoma on the chest radiograph was investigated. Many studies have been presented in the literature showing significant observer variability in the interpretation of chest radiographs $s^{10-13}$ with inter-observer kappa values ranging from 0.37 to 0.72 concerning different pathology on the chest radiograph. ${ }^{11.12 .14}$ This appeared also the case in our study concerning the detection of early lung cancer on the chest radiograph. To date, a kappa value smaller than 0,4 means a poor agreement between the observers, a value between 0.4 and 0.75 a moderate to good agreement and a value larger than 0,75 a good agreement. The sensitivity varied between $20 \%$ and $60 \%$ (mean $33 \%$ ) and the specificity between $88 \%$ and $97 \%$ (mean $92 \%$ ). These results show that the validity in detecting small lesions varies widely among the observers. The low sensitivity often means numerous false negative decisions. The inter-observer kappa in our study varied between 0.31 and 0.46 (mean 0.38 ), a low agreement rate and the intra-observer kappa between 0.42 
and 0.66 (mean 0.53 ) a moderate agreement rate. So, often the inter-and the intraobserver variations are substantial. For diagnostic studies this is a low to moderate score. One criticism of this study can be that the chest radiographs used were derived from patients with missed lesions in daily clinical practice, so making it unrealistically difficult. This may be true but, firstly, these are the problem cases in everyday clinical practice that we have to cope with (the easy ones are not the problem) and, secondly, the whole study is artificial and therefore an extrapolation to daily clinical practice is not possible. This study also showed that chest physicians report with a higher specificity but a somewhat lower sensitivity than the radiologists. This suggests that radiologists and chest physicians look upon the chest radiographs in different ways. The radiologists are eager to find even the smallest lesion, afraid of false negatives i.e. missing a malignancy, whereas the chest physicians can only be persuaded when the lesion is really suspected of being a malignancy, afraid of false positives because of further (invasive) diagnostic procedures such as bronchoscopy or biopsies in the chest. With this in mind, in clinical practice, the combined judgement of a radiologist and a chest physician is preferable. In our study it also appeared that the trained radiologists performed better than their residents and chest radiologists performed better than radiologists with other subspecialties or general radiologists. So, not only experience but also training and subspecialization is to be recommended as well as periodical training and an expertise check with consequences, with a view to obliglatory refresher courses. These measures will improve the mean validity and lower the inter-observer and the intramobserver variation.

Neverthelless, more needs to be done to improve the level of diagnostic performance of the chest radiograph in the detection of lung cancer. Several methods which could improve the diagnostic performance of reading radiographs have been described in the literature. Some studies have shown that providing clinical information improves diagnostic accuracy ${ }^{15-17}$ although the improvement is sometimes statistically not significant. Another method to improve the diagnostic performance in detecting small lesions is by double reading as was successfully done in mammography screening ${ }^{18-}$ ${ }^{19}$ and in one study concerning multiple interpretations of chest radiographs. ${ }^{20} \mathrm{We}$ investigated the impact of previous films, clinical information, double reading and dual reading in a study presented in chapter 4 . The results were somewhat disappointing. The provision of clinical information and the previous chest radiographs resulted in a marginal improvement in the detection of lung cancer presenting as a small nodular lesion. Double reading resulted in, as can be expected an increase of the sensitivity, from $33 \%$ to $46 \%$ but there was a decrease of specificity from $92 \%$ to $87 \%$. This results in a statistically insignificant increase of the odds ratio of $4 \%$ in the detection of early lung cancer. The costs and efforts of double reading in clinical practice are high and are not justifiable in view of the poor results. Dual reading, however, yielded slightly better results with an increase of sensitivity from $33 \%$ to $37 \%$ and an unchanged specificity of $92 \%$ which resulted in an increase of the odds ratio at $14 \%$ in detection, not high but statistically significant. Regarding the costs and efforts of dual reading and its results, it remains questionable if it is worthwhile.

These results imply that the difficulty of detecting lesions on the chest radiograph is intrinsically related to the poor visibility of the lesions on the chest radiograph, and diagnostic performances are hardly improved by the provision of clinical information, previous radiographs and double- or dual reading. Therefore in chapter 5 the radiological characteristics of missed lesions on the chest radiograph were analyzed 
and compared with the lesions that were not missed. In the literature poor lesion conspicuity resulting from superposing structures such as ribs, clavicles, vessels, hilar or mediastinal structures, or the small size and irregular shape of the lesion constitute the most common reason for missing the lesion on the chest radiograph, compared to other factors such as technically poor images, inadequate observations or interpretations and short observation time. ${ }^{21-23}$ About $35 \%$ of lung cancers are located centrally but nearly half of the missed lung cancers (45\%) were centrally located. This can be explained by the fact that on the chest radiograph the most superposing structures are situated centrally such as the hili. Regarding the superposing structures all together, it appears that in the group of missed lesions superposing structures were present in $71 \%$ of cases, whereas in the detected cases in only $2 \%$. Concerning small lesions, it appears that $28 \%$ of the missed lesions had a diameter of $1 \mathrm{~cm}$ or less and lesions with low opacity and unsharp borders, amounted to $70 \%$ of the lesions missed in our series.

Some of these problems might be solved by digital chest radiography. Several studies reveal that the digital system performs at least as well as the conventional chest radiographs in the detection of small pulmonary nodules and it is sometimes even better (especially when lesions are located in the mediastinum). ${ }^{24-27}$ The advantage of the digital systems is that the observer can adjust window levels and widths and magnify details. Frank et al found that the detection of parenchymal masses was better on a digital hard copy than on a conventional film because of the improved redistribution of contrast information. ${ }^{28}$ The performance of the observers using the interactive display in detecting pulmonary nodules is not statistically different from the results obtained from laser printed radiographs: some perform better, some less well. ${ }^{26}$ A disadvantage of working with an interactive display is that the time required for completion is twice that for the hard copy sessions. This increase is due largely to the interactive adjustment of image contrast and brightness. ${ }^{29}$ Apart from the slightly better sensitivity in nodule detection with digital chest radiography it seems that also a better characterization of the pulmonary nodule is possible. This is especially true with regard to the identification of calcium in the nodule, a sign of benignity. ${ }^{30-32}$

$\mathrm{CT}$ is thought to be better in detecting small lesions and lesions with unsharp borders because it bypasses overlying structures and can achieve better contrast between the lesion and the surrounding anatomical structures by adjustment of the window settings. A study of the Anti-Lung Cancer Association (ALCA) in Tokio found that the average size of lung cancers detected decreased after the introduction of CT; the average size detected by chest radiographs was $30 \mathrm{~mm}$ and those detected only on CT had an average size of $12 \mathrm{~mm}$. This is particularly important because it is assumed that the smaller the size of the tumor, the higher the survival rate. ${ }^{3.32}$ These advantages of CT over the chest radiographs results in a detection of lung cancer in an early stage and improves its resectability. In a study of Fontana et al. ${ }^{34} 96 \%$ of the CT-detected lung carcinomas were resectable whereas in the Mayo Lung Project the lung carcinomas predominantly detected by chest radiographs were only resectable in $51 \%$ of the patients. Beside the fact that CT is much more sensitive for the detection of calcification in a lesion (indicating benignity), it is very capable of identifying growth in small nodules in a short period of time whereas in a conventional chest radiograph estimation of growth and measurement is very limited by differences in patient rotation, magnification and blurred edges. ${ }^{35}$

Regarding the foregoing, it is very plausible that the CT is a better fool for detecting early lung carcinoma in daily clinical practice and in screening and that the chest 
radiograph is insufficient. To find this out, a literature study is presented in chapter 6 to investigate what the diagnostic performance is of the chest radiograph and the chest $C T$ in the detection of lung cancer. It appears that many studies have been performed dealing with the diagnostic performance of the chest radiograph both in daly clinical practice and in lung cancer screening studies and only a few concerned the diagnostic performance of $\mathrm{CT}$. There are few studies comparing the chest radiograph and the $\mathrm{CT}$ in detecting lung carcinoma, both performed in the same patients. Another difficulty was that these studies were hard to compare because of the different study designs. With regard to screening studies by means of chest radiographs it appears that the incidence of lung cancer increases and that screening does not influence lung cancer mortality These results were confirmed by a follow up study of the Mayo Lung Project, ${ }^{30}$ so screening early lung cancer with chest radiographs cannot be advocated. In one study, ${ }^{\circ}$ comparing the results of the chest radiographs and CT in detecting early lung cancer, a sensitivities of $45 \%$ and $68 \%$ was found respectively, implying that CT was superior. When CT was used as a gold standard, as in several studies, the sensitivity of the chest radiograph was only $25 \%$. Sone et al. ${ }^{37}$ found in their study that on low-dose CT 10 times as many malignancies were detected as on the chest radiograph. These results suggest that CT could reduce mortality of Jung cancer and so justify screening. To prove this, further investigation should be performed. We think it is defendlable to state that in all patients who have symptorns which are suspicious of lung cancer, a chest CT should be performed, regardless of the results of the chest radiograph and furthermore that screening for lung cancer by means of chest radiographs is ulseless.

In the future, computed-aided diagnosis (CAD) for lung cancer can assist the radiologist improving visualization, detection and characterization of early stages of the disease. To improve visualization, image processing techniques have been developed to improve contrast, enhancing suspected regions for the visual detection of nodules. ${ }^{38.40}$ In order to improve detection, techniques have been developed for automatic detection of candidate nodules by subtraction of a nodule-suppressed image from one that is nodule-enhanced. ${ }^{39,41}$ With regard to characterization, computed measurements of shape, surface irregularity, density gradients and fractional texture analysis, a certain distinction can be made between benign and malignant nodules. ${ }^{42-43}$ Kobayashi et al. ${ }^{39}$ found in their study that CAD statistically significantly improved radiologists' performance in detection of lung nodules. The computer's output appears to beneficial when it involves a true-positive nodule detection, the observers" performance does not appear to be degraded with computer-generated false-positive nodule detection.

CT has the advantage over the chest radiograph that there is no summation by over projection: the intensity values in a voxel are directly related to the material situated in that voxel. In CT there is, however, a problem of distinguishing nodules from vascular structures. To overcome this problem the lung region is identified or the region of interest is defined. A simple density measurement to separate nodules and vessels does not work, so three dimensional morphology filters are used to remove the long cylindrical vessels from three dimensional images. ${ }^{44}$ When the nodule is identified, characterization of the lesion can take place by measuring three dimensional shape and density distribution. ${ }^{45}$ Additionally, any growth of the lesion. what is suspicious for malignancy, can be monitored very accurately with $\mathrm{CT}$; a change in volume of $1 \%$ to $2 \%$ can be detected, so a short interval of 2-3 months can be used for follow up in order to obtain evidence of growth. ${ }^{46-47}$ 
Regarding the foregoing; CT and CAD are very promising in detecting and characterizing small lesions and can play a major role in clinical practice and for screening purposes.

\section{References}

1. Lillington GA. Management of solitary pulmonary nodules. Postgrad Med 1997; 101: 145-150.

2. Stitik FP, Tockman MS. Radiographic screening in the early delection of lung cancer. Radiol Clin North Am 1978; 16: 347-366.

3. Heelan RT. Flehinger BJ, Melamed MR, et al. Non-small-cell lung cancer: results of the New York screening program. Radiology 1984: 151:289-293

4. Muhm JR, Miller WE, Fontana RS, et all. Lung cancer detected during a screeining program using four-month chest radiographs. Radiology $1983 ; 148: 609-615$.

5. Fontana RS, Sanderson DR, Woolner LB, et al. Lung Cancer Screening: The Mayo Program. J Occup Environ Med 1986; $28: 746$

6. Landis SH, Murray T, Bolden S, et al. Cancer statistics-1998. CA Cancer J Clin 1998;48:6

7. Strauss GM. Lung cancer screening and randomized population trials. In Dominioni L, Strauss GM (eds). Procedings of the International Conference on Prevention and Early Diagnosis of Lung Cancer. Varese, 1998: 57 .

8. Mountain CF. Revision in the International System for Staging Lung Cancer. Chest 1997; 111 $1710-1717$.

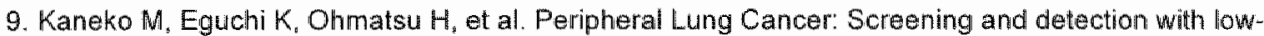
dose spiral CT versus radiography. Radiology 1996; 201: 798-802.

10. Herman PG, Gerson DE. Hessel SJ, et al. Disagreements in chest roentgen interpretation. Chest $1975 ; 68: 278-282$.

11. Young $M_{1}$ Marpie TJ. Interobserver variability in the interpretation of chest roentgenograms of patients with possible pneumonia. Arch Intern Med 1994" 154: 2729-2732.

12. Albaum MN, Hill LC. Murphy $M$, et al. Interobserver reliability of the chest radiograph in communityacquired pneumonia. PORT Investigators. Chest 1996; 110: 343-350.

13. Tudor GR, Finlay $D$, Taub $N$. An assessment of inter-observer agreement and accuracy when reporting plain radiographs. Clin Radiol 1997; 52:235-238.

14. Melbye $\mathrm{H}$, Dale $\mathrm{K}$. Interobserver variability in the radiographic diagnosis of adult outpatient pneumonia. Acta Radiol 1992; 33: 79-81

15. Schreiber MH. The clinical history as a factor in roentgenogram interpretation. JAMA. 1963; 185: $137-139$.

16. Doubilet P, Herman PG. Interpretation of radiographs: Effect of clinical history. AJR 1981; 137: $1055 \cdot 1058$.

17. Berbaum KS, Franken EA, Dorfman DD, et al. Influence of clinical history upon detection of nodules and other lesions. Invest. Radiol 1988; $23: 48-55$.

18. Thurfell E. Mammography screening one versus two views and independent double reading. Acta Radiol 1994; $35: 345-349$.

19. Thurfell EL, Lernevall KA. Taube AAS. Benefit of independent double reading in a populationbased mammography screening program. Radiology 1994; 191: 241-244.

20. Hessel SJ, Herman PG, Swensson RG. Improving performance by multiple interpretations of chest radiographs: Effectiveness and costs. Radiology 1978: 127: $589-594$

21. Austin JHM, Romney BM, Goldsmith LS. Missed bronchogenic carcinama: radiographic findings in 27 patients with a potentially resectable lesion evident in retrospect. Radiology $1992 ; 182 ; 115-122$.

22. Brogdon BG, Kelsey CA, Mosely RD. Factors affecting perception of pulmonary lesions. Radiol Clin North Am 1983; 21: 633-665.

23. Kelsey CA, Mosely RD, Brogdon BG, et al. Effect on size and position on chest lesion detection. A.JR 1977; 129: 205-208.

24. Swenson $S J$, Gray JE, Brown $\mathrm{LR}_{a}$ et al. A new asymmetric screen-film combination for conventional chest radiography: evaluation in 50 patients. AJR 1993; 160: $483-486$.

25. Slasky BS, Gur D, Good WF, et al. Receiver Operating Characleristic Analysis of Chest Image Interpretation with Conventional, Laser-printed, and High-Resolution Workstation Images. Radiology 1990; 174: 775-780.

26. Leppert AGA, Prokop M, Schaefer-Prokop CM, Galanski M, et al. Detection of Simulated Chest Lesions: Comparison of a Conventional Screen-Film Combination, an Asymmetric Screen-Film System, and Storage Phosphor Radiography. Radiology 1995; 195: 259-263. 
27. Widoff B, Aberle DR, Brown $K$, et al. Hard copy versus soft copy display of 2,000 digital chest images: ROC study with simulated lung nodules (abstr). Radiology 1989; 173: 401.

28. Frank MS, Jost RG, Blaine GJ, Moore SM, Whitman RA, Hagge R. Interpretation of mobile chest radiagraphs from a high-resolution CRT display (abstr). Radiology 1989; 173: 401.

29. Cox GG, Cook LT, MeMiltan JH, Rosenthal SJ, Dwyer 111 SJ. Chest Radiography: Comparison of High-Resolution Digital Displays with Conventional and Digital Film. Radiology 1990; 176: 771-776.

30. Fraser RG, Hickey NM, Niklason LT, et al. Calcification in pulmonary nodules: Detection with dualenergy digital radiography. Radiology $1986 ; 160: 595-601$.

31. Firaser RG, Sanders C. Bames GT, et al. Digital imaging of the chest. Radiology 1989; 171: $297-307$.

32. Niklason LT, Hickey NM, Chakraborty DP, et al. Simulated pulmonary nodules: Detection with dualenergy digital versus conventional radiography. Radiology 1986; 160: 589-593

33. Inoue $K$, Sato $M$, Fujimura $S$, et al. Prognostic assessment of 1310 patients with non-small cell iuning cancer who underwent complete resection from 1980 to 1993. I Thorac Cardiovasc Surg 1988: 116: 407 .

34. Fontana RS, Sanderson DR, Taylor WF, et al. Early lung cancer detection: Results of the initial (prevallence) radiologic and cytologic screening in the Mayo Clinic Study. Am Rev Respir Dis 1984; 130: 561

35. Yankelevitz DF, Gupla $R$, Zhao $B$, et al. Repeat CT scanning for evaluation of small pulmonary nodules. Radiology 1999; 212:561-566.

36. Marcus PM, Bergstrahl EJB, Williarms DE, et al. Lung Cancer Mortality in the Mayo Lung Project: Impact of Extended Follow-up. J Natt Cancer Inst 2000; 92: 1308-1316.

37. Sone $S_{\text {, Takashima }} S_{i}$ Li $F$ et al. Mass screening for lung cancer with mobile spiral computed tomography scanner. Lancet $1998 ; 351: 1242$.

38. $\mathrm{Kim} \mathrm{JH}$, Im JG, Han MC, et al, Improved visualization of simulated nodules by adaptive enthancement of digital chest radiography. Acad Radiol 1994; 1: 93-99.

39. Kobayashi T, Xu XW, MacMahon $\mathrm{H}$, et al. Effect of a computer-aided diagnosis scheme on radiologists' performance in detection of lung nodules on radiographs. Radiology 1996; 199 $843-848$.

40. Sherrier RH, Chiles. $C$, Wilkinson WE, et al. Effects of image processing on nodule detection rates in digitized chest radiographs: ROC study of observer performance. Radiology 1998; 166: 447-450.

41. Yoshimura $\mathrm{H}$, Giger ML, Doi K, et al. Computerized scheme for the detection of pulmonary nodules: A nonlinear filtering technique. Invest Radiol 1992; 27: 124-129.

42. Peiss $\mathrm{J}$, Verlande $M$, Ameling $W$, et al Classification of lung tumors on chest radiographs by fractal texture analysis. Irnvest Radiol 1996; 31: 625-629.

43. Vittitoe NF, Baker JA, Floyd CE. Fractal texture analysis in computer-aided diagnosis of solitairy pullmonary nodulles. Acad Radiol 1997; 4: 96-101.

44. Kostis WJ. Reeves A.P, Yankelevitz DF, et al. Three dimensional segmentation of solitary pulmonary nodules from helical CT scans. In Lemke HU, Vannier MW, Inamura $K_{1}$ et al (eds). Proceedings of Computer Assisted Radiology and Surgery (CARS "99). Amsterdam, Elseviers Science, 1999: 203-207.

45. Reeves AP, Kostis WJ, Yankelevitz DF el al. Three dimensional shape characterization of solitary pulmonary nodules from helical CT scans. In Lemke HU, Vannier MW, Inamura $K_{\text {s }}$ et al. (eds). Proceedings of Computer Assisted Radiology and Surgery (CARS "99). Amsterdam Elsevier Sicience, 1999: 83-87.

46. Yankelevitz DF, Gupta $R$, Zhao B, et al. Small pulmonary nodules: Evaluation with repeat $C T$ preliminary experience. Radiology 1999; 212: 561-566.

4.7. Yankelevitz DF, Reeves AP, Kostis Wul et al. Determination of malignancy in small pulmomany nodules based on volumetrically determined growth rates. Radiology $1998 ; 209: 375$ 


\section{Chapter 8}

\section{Summary and conclusions}

The diagnosis of non small cell lung cancer on the chest radiograph can be very troublesome. Various studies in the literature have dealt with this subject, investigating the causes and giving explanations for missing the diagnosis on the chest radiograph. For decades the chest radiograph and conventional tomography were the only tools for visualizing lung cancer. Nearly two decades ago computed tomography was added but still nowadlays, in daily clinical practice, the chest radiograph is the first choice to search for lung cancer in patients in whom there is a suspicion of malignancy or for screening purposes. In large screening studies for lung cancer in the 1970's and 1980's in high risk populations, the chest radiograph (and sputum cytology) was used for the detection of early lung cancer.

Especially from the screening studies but also from other studies and case reports, it has become clear that there is a certain percentage of error in detecting early lung carcinoma. This miss rate is also a well known phenomenon in mammographic screening. In screening mammography, the miss rate is more or less successfully lowered by providing previous films for comparison and by double reading. In equivocal chest radiographs further investigation is performed; predominantly by performing computed tomography. Many investigations have already shown that CT has many advantages over chest radiograph in detecting early stages of lung cancer. Several investigations have already been carried out to compare the effectiveness of the chest radiograph with that of the chest CT in detecting and screening for early lung cancer.

Many studies addressed the miss rate in the detection of lung cancer on the chest radiograph. However, these studies were experimental studies often concerning small groups of selected patients or experimental studies with small lesions on a chest radiograph and with selected observers. No studies have been reported that addressed the miss rate in daily clinical practice. An accurate estimation of the precise value of the chest radiograph in the detection of lung carcinoma in clinical practice is thus difficult to calculate. It is not common practice to perform a chest CT as first diagnostic tool in patients to detect lung carcinoma. One of the reasons for this is that the precise value of the chest CT in the detection of lung carcinoma is not fully known. Several studies report that CT appears to be a better diagnostic tool for detecting lung carcinoma but to what extent with regard to the chest radiographs is not known

The aim of this study was to investigate what the miss rate is in daily clinical practice in the detection of lung cancer on the chest radiograph and to analyze the radiological characteristics of the missed lesions. In addition the inter-and intra observer variability is investigated as well as the impact on the detection rate of providing previous films and clinical information together with the effect of double reading and dual reading. Finaliy, a review is carried out to investigate what is known from the literature about the role of (spiral) CT in relation to the chest radiograph in the detection of early lung cancer. 
Chapter 1 gives a shot review of the epidemiology and histology of lung cancer. The TNM staging classification is presented in relation to prognosis and therapy. Then the radiological presentation of the four major types of non small cell lung cancers on the chest radiographs is described. The problems and limitations of the detection of lung carcinoma on the chest radiograph, the inter-and intra observer variability in interpreting the chest radiograph and the role of screening for lung carcinoma are discussed. Finally, the objectives of this thesis are discussed and a description of the study design and patient material is given.

In chapter 2 the miss rate of lung cancer on the chest radiograph in daily clinical practice in The Atrium Medical Center. Heerlen, The Netherlands, is described. During the years 1992 to 1995,495 patients presented with NSCLC of whom in 396 ( 300 males and 96 females) a complete set of chest radiographs was available. In 259 of the 396 patients, lung carcinoma was visible retrospectively on the chest radiograph as a (small) lesion. In $49(19 \%)$ of these 259 patients, the lesion was missed on the chest radiograph. The median diameter of the missed lesions was 16 $\mathrm{mm}$ whereas that of the detected lesions was $60 \mathrm{~mm}$. Superposing structures were present in $71 \%$ of the patients with missed lesions whereas in only $2 \%$ of the cases they were present with detected lesions. In $16(33 \%)$ of the 49 patients the lesion was missed twice on the consecutive chest radiographs and in 6 (12\%) patients the lesion was missed more than twice. Twelve $(24.5 \%)$ patients had a delay of less than 6 months, $9(18 \%)$ a delay between 6 and 12 months, $16(33 \%)$ a delay between 12 and 24 months and $12(24.5 \%)$ a delay of more than 24 months. In $22(35 \%)$ of the 49 patients with missed lesions, the patients remained in stage $T 1$ (according to the radiological staging on the chest radiograph), 6 patients (12\%) remained in stage T2 but in 21 (43\%) patients the tumor stage changed from stage T1 to stage T2. Taking this into account together with a miss rate of $19 \%$, there is a definitive impact on prognosis. When (in terms of staging) the $\mathrm{N}$ status and the $\mathrm{M}$ status of the patient are assumed to be unchanged, in this study the 5-year survival dropped by $23 \%$ in $43 \%$ of the patients with undetected early lung cancer.

In chapter 3 a study is presented on observer performance in the detection of lung cancer on the chest radiograph. The chest radiographs of $100 \mathrm{clinical}$ cases were obtained from: 30 patients with initially missed lung cancer presenting as a lesion on the chest radiographs with good set of posterior-anterior radiographs and a previous set for comparison (selected out of the group presented in chapter 2), 35 patients with cardiopulmonary diseases other than lung carcinoma and 35 patients with no abnormalities visible on the chest radiographs. These chest radiographs were presented in a random order to 14 observers consisting of 10 experienced radiolog"sts, 2 experienced chest physicians and 2 residents in radiology, who were all unaware of the study design, and who were asked to fill in a prearranged check list. The mean sensitivity and specificity in the detection of NSCLC of the radiologists were 0.36 and 0.90 respectively. For the 2 chest physicians the mean sensitivity and specificity were 0.29 and 0.96 and for the residents 0.25 and 0.94 , respectively. It was not possible to construct a ROC curve (sensitivity plotted against one minus the specificity) with these results indicating significant differences in the ability of the observers to detect small lesions. The calculated Spearman rank correlation coefficient of the inter- and intra observer kappa with the diagnostic Odds Ratio of respectively 0.34 and 0.21 indicated that there was no significant correlation between consistency parameters and validity parameters. The Spearman rank correlation coefficient between the inter observer kappa and the intra observer kappa was 0.68 showing that these kappa values were clearly correlated. For the detection of small 
nodular lesions on the chest radiograph, a high value of the inter observer kappa does not predict high values for the validity parameters. Observers with a low inter observer kappa will probably perform poorly in detecting nodular lesions. Double reading could improve these results, i.e. it will increase the sensitivity but it consequently reduces the specificity and is very time consuming and expensive. The level of experience influences the diagnostic performance positively.

Subspecialization or specific training might improve the diagnostic validity. A recommendation with more consequences for clinical practice would be a periodical quality check.

In chapter 4 the impact of previous films "clinical information and the possible benefit of double reading and dual reading above single reading was studied. The same study material and observer team was used as in the study presented in chapter 3 . In this study session 7 of the 14 observers (5 radiologists, one chest physician and one resident in radiology) were given no extra information but the other 7 ( 5 radiologists, one chest physician and one resident in radiology) were provided with previous chest $X$-rays and standardized clinical information namely: suspicion of malignancy. The mean sensitivity and specificity in the detection of lung carcinoma on the chest radiograph in this second study session without additional previous chest radiographs and clinical information were 0.28 and 0.93 respectively, with additional information 0.31 and 0.93 . The improvement of the diagnostic Odds ratio was small $(+4 \%)$; which statistically was not significant. For double reading 7 pairs of abservers were formed and the combined results of these pairs were compared with the results of the single reading in the first session (chapter 3 ). For dual reading, 5 pairs of observers were formed, each pair receiving the chest radiographs simultaneously. These results were also compared with the results of the first study session (chapter 3 ). The overall sensitivity and specificity in single reading were 0.33 and 0.92 , in double reading 0.46 and 0.87 and in dual reading 0.37 and 0.92 , respectively. Thus with double reading the sensitivity increases at the expense of the specificity and in dual reading sensitivity is also increased but the specificity is hardly changed. The diagnostic Odds Ratio increases only by $4 \%$ in double reading, which is not significant, but dual reading improves the diagnostic Odds Ratio by $1.4 \%$, a slightly better result. In other words; dual reading slightly improves the observers ability to discriminate whether lung cancer is visible or not on the chest radiograph with regard to single reading, while double reading shows no significant improvement.

In chapter 5 the radiological characteristics of all missed lung cancers in daily clinical practice presenting as lesions on the plain chest radiograph found in the study presented in chapter 2 are described. In the group of 49 missed lung cancers. $27(55 \%)$ of the lesions were peripherally located, $22(45 \%)$ centrally. In $32(63 \%)$ patients the lesions were located in the right lung and in $31(63 \%)$ of the cases the lesion was situated in the upper lobes, in 18 patients $(37 \%$ ) the lesion was recorded in the lower lobes. The size of the missed lesion varied between $0.5 \mathrm{~cm}$ and $7 \mathrm{~cm}$ with a median diameter of $0.8 \mathrm{~cm}$. The central lesions were larger than the peripheral lesions. In $70 \%$ of the missed cases, the lesions were partly or totally unsharply bordered and only $30 \%$ had sharp borders. Superimposed structures such as ribs, spine, clavicles, vessels and the heart were seen in $33(67 \%)$ of the missed lesions. Three of the $49(6 \%)$ missed lesions were only detectable on the lateral chest radiograph and not on the posterior anterior chest radiograph. The most frequent reason for missing a lesion more than once in a patient was the fact that the lesions grew slowly over several years: in $16(33 \%)$ cases the lesion was missed twice on 
consecutive chest radiographs, and in 6 of the $49(12 \%)$ cases even three times or more.

In chapter 6 a review of the diagnostic performance of the chest radiograph and the chest $\mathrm{CT}$ in the detection (and characterization) of lung cancer is presented. All English language articles published since 1980 for chest radiographs and since 1985 for CT of the chest were searched for. Twenty studies were found which met the inclusion criteria. For the detection of lung cancer by chest radiograph the sensitivity ranged between $26 \%$ and $81 \%$ and specificity between $85 \%$ and $99.6 \%$. For the chest CT after a positive result on the chest radiograph, the sensitivity ranged from $88 \%$ to $100 \%$ and the specificity between $70 \%$ and $100 \%$. Comparing the chest radiograph and the chest CT, performed in all patients in a study, sensitivities of $45 \%$ and $68 \%$ respectively were found. When CT is used as the gold standard, as in an other study, the sensitivity of the chest radiograph is $25 \%$. With regard to lung cancer screening by means of the chest radiograph it appears that screening does not influence mortality and it increases the incidence. These results show that the detection rate with the chest CT is significantly higher than with the chest radiograph and that screening for lung cancer by the chest radiograph cannot be advocated. These results also imply that chest CT is a useful tool for screening purposes and that it, unlike the chest radiograph, could possibly reduce lung cancer mortality. Also a more aggressive approach in patients with clinical symptoms suggestive of lung cancer but negative chest radiographs by carrying out a chest CT can be defended. These results indicate that chest CT is significantly better than the chest radiograph in the characterization of lesions and also in detecting the lesions but further studies have to be performed to confirm this more strongly. The general discussion, presented in chapter 7 , includes all previous studies leading to the following conclusions:

1. A miss rate in the detection of lung carcinoma presenting as a (nodular) lesion in daily clinical practice is approximately $19 \%$ and appears one of the most frequently missed diagnoses in radiology.

2. The most important reason for missing a lesion on the chest radiagraph is poor lesion conspicuity i.e. the lesion is difficult to identify or separate from the surrounding or overlying structures. This is especially the case in small (early) lesions.

3. The vallidity of detecting lung carcinoma on the chest radiograph varies widely among different observers. No significant relation between the consistency parameters and validity parameters could be detected but the inter-and intra observer variation showed good correlation. The level of experience is likely to influence the diagnostic performance.

4. The improvement in detecting lung cancer on the chest radiograph by providing previous films and clinical information is negligible. With double reading, the sensitivity increases at the cost of the specificity " hardly resulting in an increased accuracy. Dual reading increases sensitivity but hardly influences specificity. although showing a slightly better result than double reading.

5. In the literature, the diagnostic accuracy of chest CT appears to be significantly better than that of the chest radiograph but well conducted comparative studies are limited. Some investigations have shown that low dose spiral CT is a better tool than chest radiography for detecting early lung cancer. 
6. In the future, digitalization with its ability of postprocessing and Computer-Aided Diagnosis (CAD) is promising regarding the results of many (often still experimental) studies.

In conclusion, the detection of lung cancer on the chest radiograph is far from perfect.

In view of the promising results with low dose spiral CT, this modality could become a screening procedure of first choice in lung cancer and replace the chest radiograph as an investigation of first choice in the evaluation of patients with suspicion of lung cancer.

Further investigation needs to be performed to acknowledge the potentials and benefits of both low dose spiral CT in the detection of lung cancer at an early stage and digitalization and CAD (Computer-Aided Diagnose). 



\section{Summary in Dutch}

De diagnostiek van het niet-kleincellig longcarcinoom is vaak lastig. De thoraxfoto als eerst gebruikte diagnostische techniek stelt regelmatig teleur en er is daarom al veel onderzoek gedaan naar de nauwkeurigheid van deze thoraxtoto en naar mogelijke oorzaken van het niet herkennen van afwijkingen op deze foto. Daarbij is gebleken dat een niet onaanzienlijk aantal tumoren werd gemist en dat deze dan vaak nog in een vroeg stadium verkeerden. Toch was de thoraxtoto jarenlang de enige methode om een longcarcinoom in beeld te brengen. Sinds 20 jaar is daartoe ook computertomografie (CT) beschikbaar maar toch is in de dagelijkse praktijk de thoraxfoto nog de onderzoekmethode van eerste keuze bij verdenking op longkanker.

Dit op een röntgenfoto niet herkennen van tumoren in een vroeg stadium is een bekend fenomeen uit screeningsstudies op borstkanker met behulp van mammografie. Daarbij kon het percentage fout negatieve diagnosen echter worden verminderd door middel van "double reading". Dat wil zeggen door de foto's door twee beoordelaars onafhankelijk van elkaar te laten beoordelen. Ook het ter beschikking hebben van oude foto"s ter vergelijking verminderde bij mammografie het aantal fout negatieve diagnosen.

In de dagelijkse praktijk wordt momenteel bij twijfel over de aanwezigheid van een afwijking op de thoraxfoto of over de aard van die afwijking meestal verder onderzoek verricht met behulp van CT. Diverse onderzoeken hebben immers aangetoond dat het CT onderzoek van de longen voordelen biedt bij de diagnostiek van het longcarcinoom boven de thoraxfoto. CT is zowel sensitiever als specifieker maar deze methode is echter wel duurder, meer strallingsbelastend en als snelle routine procedure amper uitvoerbaar.

In de literatuur zijn diverse studies verschenen over het missen van de diagnose longcarcinoom op de thoraxfoto met analyses over frequentie en oorzaken. Het aantal gemiste diagnosen in een dagelijkse klinische praktijk is echter nooit onderzocht. Hierdoor is een nauwkeurige inschatting van de waarde van de thoraxfoto voor de diagnostiek naar longcarcinoom in de dagelijkse klinische praktijk moeilijk te bepalen en daardoor is evenmin aan te geven in welke mate CT mogelijk superieur is boven de thoraxfoto.

Het doel van deze studie is om te onderzoeken hoe vaak de diagnose longcarcinoom op de thoraxfoto door een waarnemer wordt gemist alsmede de radiologische karakteristieken van de gemiste longcarcinomen te analyseren. Tevens is de interen intra-waarnemervariatie van het detecteren van longkanker met behulp van een thoraxfoto onderzocht alsmede de invloed van het beschikbaar hebben van klinische informatie en van oude foto"s ter vergelijking. Ook is het effect van "double reading" (twee onafhankelijk van elkaar werkende beoordelaars) en van "dual reading" (twee simultaan werkende beoordelaars die de foto"s waarover zij het oneens waren nogmaals beoordeelden) bekeken. Tenslotte is een literatuur onderzoek verricht om te bepalen wat reeds bekend is omtrent de rol van de (spiraal-). CT ten opzichte van de (conventionele) thoraxfoto met betrekking tot de detectie van longcarcinoom.

In hoofdstuk 1 wordt in het kort de epidemiologie en de histologische typering wan het longcarcinoom besproken. De stagering volgens de TNM classificatie wordt in relatie tot de prognose en therapie beschreven. Vervolgens worden de radiologische 
karakteristieken van de vier belangrikste typen van niet-kleincellig longcarcinoom (NSCLC) op de thoraxfoto beschreven. De problemen en beperkingen met betrekking tot de detectie van het longcarcinoom op de thoraxfoto de inter-en intrawaarnemervariatie bij de interpretatie van de thoraxfoto komen ter sprake alsmede de rol van screening op longcarcinoom. Tenslotte worden de onderwerpen van dit proefschrift, de studie-opzet en de patientengroep besproken.

In hoofdstuk 2 worden de met de thoraxfoto gemiste longcarcinomen uit de klinische praktijk van het Atrium Medisch Centrum te Heerlen beschreven. In de periode van 1992 tot 1995 presenteerden zich 495 patiënten met een NSCLC in dif ziekenhuis waarvan bij 396 patiënten ( 300 mannen en 96 vrouwen) een complete set thoraxfoto's beschikbaar was. Bij 259 van deze 396 patiënten was achteraf de tumor op de thoraxfoto zichtbaar als een omschreven massa (lesie) maar bij $49(19 \%)$ van deze 259 patiënten was de tumor destijds niet als zodanig herkend en dus gemist. De gemiddelde diameter wan de gemiste tumor bedroeg $16 \mathrm{~mm}$., terwijl de gemiddelde diameter van de well herkende en dus gedetecteerde tumoren $60 \mathrm{~mm}$. bedroeg. Bij $71 \%$ van de patiënten waarbij de tumor was gemist, waren er superponerende structuren aanwezig, terwijl dit maar in $21 \%$ het geval was bij patiënten waarbij de tumor niet gemist was. Bij 16 (33\%) van de 49 patiënten waarbij de tumor was gemist, werd deze op twee opeenvolgende thoraxfoto's gemilst en bij 6 $(12 \%)$ van de patiënten zelfs vaker dan twee maal. Bij $12(24,5 \%)$ patiënten ontstond door de gemiste diagnose een vertraging bij het stellen van de diagnose van minder dan 6 maanden, bij 9 (18\%) een vertraging tussen de 6 en 12 maanden, bij $16(33 \%)$ een vertraging tussen de 12 en 24 maanden en tenslotte bij $12(24,5 \%)$ patiënten een vertraging in de diagnostiek van meer dan 24 maanden.

Bij $28(57 \%)$ van de patiënten met een in eerste instantie gemist longcarcinoom veranderde het tumorstadium door de vertraging in diagnostiek niet. Tweeëntwintig patiënten $(45 \%)$ bleven in tumorstadium 71 . Zes patiënten $(12 \%)$ behielden stadium T2. Ten gevolge van de vertraging in de diagnose veranderde het tumorstadium bij 21 van de 49 patiënten ( $43 \%$ ) van T1 naar T2. Het niet herkennen van de tumor op de de thoraxfoto heeft dus vanwege deze veranderde $T$ stagering een duidelijke invloed op de prognose van de patiënt. Gesteld dat bij deze patiënten de N en M status niet veranderen, dan zou bij hen de 5-jaars overlevingskans dalen met $23 \%$ Met andere woorden: door gebruik te maken van de thoraxfoto werd bij $19 \%$ van de patienten de diagnose longkanker te laat gesteld en daalde bij ongeveer de helft van hen de prognose beduidend.

In hoofdstuk 3 wordt de inter-waarnemer variatie bij de detectie van longcarcinoom op de thoraxfoto onderzocht. Er werden thoraxfoto's van 100 patiënten uit de klinische praktijk maar met bekende pathologie geselecteerd waarvan zowel een goede voor-achterwaartse en zijdelingse foto als ook een set oude foto's ter vergelijking beschikbaar waren. De totale groep bestond uit: 30 patiënten (geselecteerd uit dle groep van patiênten gepresenteerd in hoofdstuk 2) met een in eerste instantie op de thoraxfoto niet herkend longcarcinoom dat zich presenteerde als een kleine haardvormige op de foto; 35 patiënten met een cardiopulmonale ziekte anders dan longcarcinoom en 35 patiënten zonder afwijkingen op de thoraxfoto. De thoraxfoto's werden in willekeurige volgorde getoond aan 14 waarnemers: 10 ervaren radiologen, 2 ervaren longartsen en twee radiologen in opleiding. De waarnemers waren niet op de hoogte van de opzet van de studie en werden verzocht de foto's op een gestandaardiseerde manier te beoordelen. De gemiddelde sensitiviteit en specificiteit van de detectie van het niet-kleincellig longcarcinoom op basis van de interpretatie van de ervaren radiologen bedroeg respectievelijk 0,36 en 0,90 , op 
basis van de interpretatie van de wee longartsen respectievelijk 0,29 en 0,96 en op basis van de interpretatie van de radiologen in opleiding respectievelik 0,25 en 0,94 . Er kon geen ROC-Curve worden geconstrueerd op basis van de sensitiviteiten en specificiteiten van deze 14 waamemers hetgeen een significant verschill in de mate van detectie wan kleine tumoren op de thoraxfoto tussen de warnemers inhoudt. De berekende Spearman rank correlatie coëfficient van de inter-en intra-waarnemer kappa enerzijds en de diagnostische Odds Ratio anderzijds van respectievelijk 0,34 en 0,21 duiden er op dat er geen significante correlatie is tussen de consistentieparameters en de validiteits-parameters. De Spearman rank correlation coefficient tussen de inter-waarnemer kappa en de intra-waarnemer kappa bedroeg 0,68 hetgeen aantoont dat deze kappawaarden met elkaar overeenkomen. Met betrekking tot de detectie van kleine nodulaire afwijkingen op de thoraxfoto kan wonden gesteld dat een hoge intra-waarnemer kappa niet automatisch hoge waarden voor de validiteits-parameters inhouden maar dat waarnemers met een lage intra-waarnemer kappa waarschijnlijk matig zullen presteren bij het detecteren van nodulaire lesies. "Double reading" zou deze resultaten kunnen verbeteren, d.w.z. het zal de sensitiviteit verbeteren doch zal vervolgens de specificiteit doen verminderen echter het is tijdrovend en kostbaar. De mate van ervaring beinvloedt de diagnostische prestaties in positive zin. Subspecialisatie en/of specifieke training wordt geadviseerd om de diagnostische validiteit te verbeteren. Het is aan te bevelen periodieke kwaliteitscontroles van de prestaties van de waarmemers te houden.

In hoofdstuk 4 wordt de invloed van het beschikken over klinische informatie en voorgaande thoraxfoto"s ter vergelijking alsmede hel mogelijke voordeel van "double reading" en "dual reading" boven het beoordelen door een enkele waamemer gepresenteerd. In deze studie werd hetzelfde studie-materiaal gebruikt als in de studie gepresenteerd in hoofdstuk 3 en waren dezelfde beoordelaars ingezet. In deze studie kregen 7 van de 14 beoordelaars ( 5 radiologen, een longarts en een radioloog in opleiding) geen extra informatie, maar de overige 7 (5 radiologen, een longarts en een radioloog in opleiding) beschikten wel over voorgaande thoraxfoto's ter vergelijking en gestandaardiseerde klinische informatie namelijk: verdenking op maligniteit. De gemiddelde sensitiviteit en specificiteit van de detectie van longciarcinoom op de thoraxfoto zonder additionele informatie en oude foto"s bedroegen in deze studie respectievelijk 0.28 en 0.93, met additionele informatie en oude foto's 0,31 en 0,93 . De verbetering van de Odds Ratio was gering $(+4 \%)$; hetgeen statistisch niet significant is. Ten behoeve van "double reading" werden 7 waarnemersparen gevormd en de gecombineerde resultaten van deze paren werden vergeleken met de resultaten van "single reading", zoals gepresenteerd in de eerste studie (hoofdstuk 3). Ten behoeve van de "dual reading" werden 5 waamemersparen gewormd; elk paar bekeek de thoraxfoto"s waarbij zij in de eerste studie van mening verschilden, opnieuw maar dan gezamenlijk. Ook deze resultaten werden vergeleken mel de resultaten uit de eerste studie (hoofdstuk 3). De gezamelijke sensitiviteit en specificiteit van "single reading" bedroegen respectievelijk 0,33 en 0,92 , in "double reading" 0,46 en 0,87 en in "dual reading" 0,37 en 0,92 . Bij "double reading" nam de sensitiviteit toe ten koste van de specitiviteit en bij "dual reading" is de sensitiviteit ook gestegen maar de specificiteit is nauwelijks beinvloed. De diagnostische Odds Ratio stijgt maar met $4 \%$ in "double reading", hetgeen niet significant is. In "dual reading" stijgt de diagnostische Odds Ratio met 14\%, hetgeen een liets beter resultaat is. Met andere woorden: "dual reading" verbetert in zeer lichte mate het discriminerend vermogen van de waarnemers met betrekking tot het feit of 
een longcarcinoom wel of niet zichtbaar is op de thoraxfoto ten op zichte van "single reading" "double reading" toont geen significante verbetering.

In hoofdstuk 5 zinn de radiologische karakteristieken van de op de thoraxfoto's gemiste long-carcinomen uit de dagelijkse praktijk beschreven, zoals gepresenteerd in hoofdstuk 2. Van de 49 gemiste langcarcinomen waren $27(55 \%)$ lesies perifeer gelegen en $22(45 \%)$ centraal. Bij $32(65 \%)$ patiënten waren de lesies in de rechter long gelegen, bij 31 (63\%) patiēnten in de boven kwabben en bij 18 (37\%) in de onderkwabben. De grootte van de gemiste lesies varieerde tussen de 0,5 en $7 \mathrm{~cm}$. met een gemiddelde diameter van $0,8 \mathrm{~cm}$. De centraal gelegen gemiste lesies waren groter dan de perifeer gelegen lesies. Bij $70 \%$ van de gemiste lesies was de lesie geheel of gedeeltelijk onscherp begrensd. Superponerende structuren zoals ribben, wervelkolom, sleutelbeenderen, vaten en het hart waren aanwezig bij 33 $(67 \%)$ van de gemiste lesies. Drie van de gemiste lesies waren alleen zichtbaar op de zijdelingse thoraxfoto en niet op de voor-achterwaartse thoraxfoto. De meest voorkomende oorzaak voor het meerdere malen missen van een lesie op de thoraxfoto bij een en dezelfide patiënt is gelegen in het feit dat de meestal kleine lesie in de loop van de jaren maar zeer traag groeit. Bij 16 (33\%) patiënten werd de lesie twee maal op opeenvolgende thoraxfoto's gemist en in 6 patiënten (12\%) werden de lesies zelfs 3 of meerdere malen gemist.

In hoofdstuk 6 is een literatuur studie beschreven handelend over de diagnostische kwaliteiten van de thoraxfoto en de CT-thorax bij de detectie (en karakterisering) van longcarcinoom. Alle engelstalige artikelem die sinds 1980 over de thoraxfoto's en sinds 1985 over de CT-thorax zijn gepubliceerd, werden opgezocht en bestudeerd. Twintig studies voldeden aan de inclusie criteria waaronder een aan de pathologie gebonden gouden standaard. Met betrekking tot de detectie van longcarcinoom met de thoraxfoto varieerde de sensitiviteit tussen de $26 \%$ en $81 \%$ en de specificiteit tussen de $85 \%$ en $99,6 \%$. Bij de CT-thorax, vervaardigd na een positieve thoraxfoto, varieerde de sensitiviteit tussen de $88 \%$ en $100 \%$ en de specificiteit tussen de $70 \%$ en $100 \%$. In een van die studie's zijn de resultaten van de thoraxfoto vergeleken met die van de CT-thorax, beiden vervaardigd bij alle patiënten waarbij een sensitiviteit en specificiteit van respectievelijk $45 \%$ en $99 \%$ (thoraxfoto) $68 \%$ en $83 \%$ (CT) werd gevonden. Indien, zoals in een andere studie, de CT-thorax als gouden standaard wordt gebruikt, bedraagt de sensitiviteit van de thoraxfoto $25 \%$ bij een specificiteit $94 \%$

Met betrekking tot screening op longcarcinoom met behulp van de thoraxfoto blijkt, dat dit de mortaliteit niet beinvloedt en de incidentie doet stijgen. Deze resultaten tonen aan, dat de detectie met CT-thorax significant hoger is dan met behulp van de thoraxfoto en dat screening op longcarcinoom door middel van het vervaardigen van thoraxfoto's niet wordt aanbevolen. Deze resultaten doen vermoeden dat CTw thorax een goede modaliteit is voor screening en dat dit, in tegenstelling tot de thoraxfoto, de mortaliteit van het longcarcinoom zou kunnen verlagen. Ook bij patiënten die klinische symptomen hebben die wijzen op longcarcinoom doch zonder afwijkingen op de thoraxfoto, is een meer aktieve benadering door middel van CT-thorax verdedigbaar.

Deze resultaten tonen aan, dat de CT-thorax beter is in hel detecteren van lesies en ook in het karakteriseren van lesies dan de thoraxfoto. Vervolg studies zullen dit nog verder moeten onderbouwen.

In de algemene beschouwing, in hoofdstuk 7, worden de resultaten van alle onderzoeken betrokken. Dit leidt tat de volgende conclusies: 
1. De diagnose longcarcinoom, zich presenterend als een kleine nodulaire lesie op de thoraxfoto, wordt in de dagelijkse praktijk in $19 \%$ van de gevallen gemist.

2. De meest voorkomende oorzaak voor het missen van een lesie op de thoraxfoto is de moeilijke differentiatie van de lesie ten opzichte van de omgevende en overprojecterende structuren. Dit is met name het geval bij kleine lesies.

3. De validiteit van de thoraxfoto met betrekking tot de detectie van longcarcinoom verschilt fors tussen de waarnemers. Er is geen significante relatie aangetoond tussen de consistentie parameters en de validiteits parameters maar de inter- en intra-waarnemers variatie correleerde goed. De mate van ervaring beinvloedt de diagnostische prestatie in positieve zin.

4. Deze validiteit verbetert niet of nauwelijks door het verstrekken van klinische informatie of van voorgaande foto's ter vergelijking. Middels "double reading"

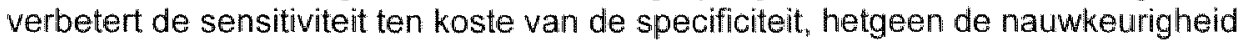
eveneens niet of nauwelijks verbetert. "Dual reading" verbetert wel de sensitiviteit en beinvloedt nauwelijks de specificiteit, hetgeen uiteindelijk een iets beter resultaat oplevert dan "double reading".

5. Uit de literatuur blijkt dat de diagnostische nauwkeurigheid van de CT-thorax significant beter is dan dat van de thoraxfoto, waarbij opgemerkt dient te worden dat vergelijkende studies schaars zijn. Enkele studies hebben aangetoond dat 'lage dosis' spiraal-CT (met een lage dosis röntgenstraling) een beter diagnosticum is dan de thoraxfoto in de detectie van longcarcinoom in een vroeg stadium.

Geconcludeerd kan worden dat de detectie van longcarcinoom met behulp van de conventionele thoraxfoto verre van volmaakt is. Gezien de veel belovende resultaten met lage dosis spiraal-CT zou deze de modaliteit van eerste keus kunnen worden boven de thoraxfoto bij screening op longcarcinoom alsmede bij de diagnostiek van patiënten waarbij klinisch een verdenking bestaat op longcarcinoom. Verder onderzoek zal moeten worden verricht naar de mogelijkheden en het nut van zowel lage dosis spiraal-CT bij de diagnostiek van longcarcinoom in een vroeg stadium als van digitalisering en CAD (Computer-Aided Diagnose). 


\section{Acknowledgments}

All research activities underlying this thesis were performed at the Department of Radiology of the Atrium Medical Center Heenlen. The reading sessions were also held at the Department of Radiology of the University Hospital Maastricht. The persons listed below made their respective contributions:

Study concepts:

Dr. R Goei (1)

Study design:

Dr. R Gaei

Drs. AGH Kessels (2)

Drs. LGBA Quekel (1)

Prof. Dr. JMA van Engelshoven (3)

Literature research:

Drs. LGBA Quekel

Dr. R Goei

Support during

PALGA consultation: Dr. PHMH Theunissen (4)

Data acquisition and data management:

Drs. LGBA Quekel

A Mordant (3)

Data analysis:

Drs. AGH Kessels

Drs. LGBA Quekel

Dr. R Goeil

Statistical analysis:

Drs AGH Kessels

Manuscript preparation:

Drs. LGBA Quekel

Drs. AGH Kessels

Dr. R Goei

Correction of English text: Dr. B| Davies (5)

Manuscript review:

Dr. R Goei

Prof. Dr. JMA van Engelshoven. 
Observers film reading sessions:

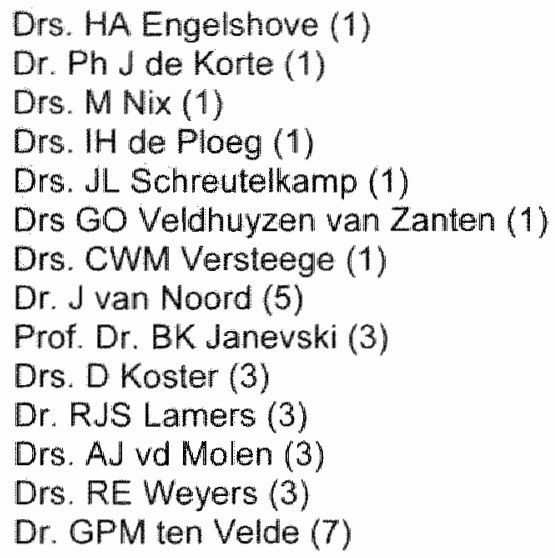

1 Department of Radiology, Atrium Medical Center Heerlen

2 Research Unit Patient Care, University Hospital Maastricht

3 Department of Radiology, University Hospital Maastricht

4 Department of Pathology, Atrium Medical Center Heerlen

5 Department of Medical Microbiology, Atrium Medical Center Heerlen

6 Department of Pulmonology "Atrium Medical Center Heerlen

7 Department of Pulmonology, University Hospital Maastricht

The investigations were supported financially by grant provided by the Hospital Board of the Atrium Medical Center. 


\section{Curriculum Vitae}

Geboren op 8 april 1963 te Heerien.

1975-1981 Atheneum B, St. Bernardinus College te Heerlen.

1981-1988 Studie Geneeskunde aan de Erasmus Universiteit te Ratterdam.

1988-1990 Vervulling Militaire Dienst plicht als Eerste Luitenant Arts, Koninklijke Landmacht.

1990-1992 Assistentschap Chirurgie Leyenburg Ziekenhuis te 's-Gravenhage.

1992-1993 Assistentschap Radiologie De Wever Ziekenhuis Heerlen.

1993-1998 In opleiding tot Radioloog in het Atrium Medisch Centrum te Heerlen.

1999-2000 Chef de Clinique afdeling Radiologie Eemland Ziekenhuis te Amersfoort.

2000-heden Werkzaam als Radioloog in Maatschapswerband in het Eemland Zlekenhuis te Amersfoort. 